UNIVERSIDADE DE SÃO PAULO

FFCLRP - DEPARTAMENTO DE PSICOLOGIA

PROGRAMA DE PÓS-GRADUAÇÃO EM PSICOLOGIA

LABORATÓRIO DE ENSINO E PESQUISA EM PSICOLOGIA DA SAÚDE - LEPPS

\title{
A recidiva do câncer pediátrico: vivências da criança e do cuidador-familiar
}

MARINA NORONHA FERRAZ DE ARRUDA

Dissertação apresentada à Faculdade de Filosofia, Ciências e Letras de Ribeirão Preto da Universidade de São Paulo, como parte das exigências para obtenção do título de Mestre em Ciências, Área: Psicologia.

Ribeirão Preto 



\title{
A recidiva do câncer pediátrico: vivências da criança e do cuidador-familiar
}

\begin{abstract}
Dissertação apresentada à Faculdade de Filosofia, Ciências e Letras de Ribeirão Preto da Universidade de São Paulo, como parte das exigências para obtenção do título de Mestre em Ciências, Área: Psicologia.
\end{abstract}

Orientador: Prof. Dr. Manoel Antônio dos Santos

RIBEIRÃO PRETO 
Autorizo a reprodução e divulgação total ou parcial deste trabalho, por qualquer meio convencional ou eletrônico, para fins de estudo e pesquisa, desde que citada a fonte.

\section{FICHA CATALOGRÁFICA}

Arruda, Marina Noronha Ferraz de

A recidiva do câncer pediátrico: vivências da criança e do cuidador-familiar.

Ribeirão Preto, 2013.

152 p. : il. ; $30 \mathrm{~cm}$

Dissertação de Mestrado, apresentada à Faculdade de Filosofia, Ciências e Letras de Ribeirão Preto/USP. Área de concentração: Psicologia.

Orientador: Santos, Manoel Antônio dos

1. Neoplasias. 2. Recidiva. 3. Psicologia da criança. 4. Família. 5. Aspectos psicossociais.

Capa: Cândido Portinari, Pipas, 1941. 
Nome: Arruda, M. N. F.

Título: A recidiva do câncer pediátrico: vivências da criança e do cuidador-familiar.

Dissertação apresentada à Faculdade de Filosofia, Ciências e Letras de Ribeirão Preto da Universidade de São Paulo para obtenção do título de Mestre em Psicologia

Aprovada em:

Banca Examinadora:

Prof.(a) Dr.(a)

Instituição: Assinatura:

Prof.(a) Dr.(a)

Instituição: Assinatura:

Prof.(a) Dr.(a)

Instituição: Assinatura: 

Aos meus pais, por me ensinarem sobre o amor e estimularem meu desenvolvimento, com exemplos de dedicação e cuidado.

Às minhas irmãs, pelo carinho do dia a dia e pela alegria que trazem à minha vida.

Ao Leandro, por me inspirar com sua paixão à ciência e estar ao meu lado nos desafios da existência. 


\section{AGRADECIMENTOS}

Às crianças e aos cuidadores-familiares, pela abertura ao encontro e por permitirem nosso olhar às ressonâncias psicológicas da recidiva em Oncologia Pediátrica, assim como pela reflexão sobre as possibilidades de cuidado;

Ao Prof. Dr. Manoel Antônio dos Santos, por me acolher como orientanda e incentivar o desenvolvimento deste estudo, compartilhando este sonho e lapidando seu tecer. Obrigada pelos ensinamentos e pelo olhar científico cuidadoso em todo o processo;

À Profa. Dra. Elisa Maria Perina, supervisora institucional deste estudo, pelo apoio e cuidado nas supervisões dos dados e pelo exemplo na atenção psicológica aos pacientes em situação de doença avançada e seus familiares;

Às Profa. Dra. Carmen Maria Bueno Neme e Profa. Dra. Regina Aparecida Garcia de Lima, pela leitura atenta e pelas valiosas contribuições no momento do Exame de Qualificação, essenciais ao amadurecimento das reflexões e decisões para a continuidade da caminhada;

Ao Centro Infantil Boldrini, pelo interesse no desenvolvimento científico e pelo apoio ao estudo das práticas assistenciais em Oncologia Pediátrica;

Ao Setor de Saúde Mental, pelo carinho com que me recebeu na fase de coleta de dados, auxiliando no contato com os participantes e no pensar sobre as vivências em cada encontro;

Aos colegas do Laboratório de Ensino e Pesquisa em Psicologia da Saúde, pelas trocas enriquecedoras na experiência da pós-graduação;

À Profa. Dra. Lucy Leal Melo-Silva, pelo carinho com o qual me recebeu e acompanhou em minha iniciação científica e pela amizade incentivadora neste e tantos outros projetos;

Ao Projeto Portinari, pela autorização de uso da obra "Pipas" que ilustra esta dissertação, como sinal da infância e da vida que se faz presente, mesmo em face da doença grave. Agradeço o cuidado que tem tido com a nossa cultura e a honra desta autorização; 
À Maria do Socorro Senne, pela cuidadosa revisão ortográfica e gramatical deste texto;

À minha família, por acompanhar meu caminhar de maneira afetuosa e inspiradora, favorecendo a concretização deste projeto e a abertura para novas possibilidades;

Às minhas amigas, que compartilharam comigo diferentes momentos da vida e do percurso na pós-graduação, pelos colos e afetos essenciais para as construções de sentido necessárias. 
"Tentei explicar aos meus pais que a vida é um presente estranho. No início, superestimamos esse presente: imaginamos ter ganhado a vida eterna. Depois subestimamos, achamos uma porcaria, curto demais, até seríamos capazes de jogá-lo fora. Enfim nos damos conta de que não era um presente, mas sim um empréstimo. Então procuramos merecê-lo."

Eric-Emmanuel Schmitt, Oscar e a Senhora Rosa, 2003 


\section{RESUMO}

Arruda, M. N. F. (2013). A recidiva do câncer pediátrico: vivências da criança e do cuidador-familiar. Dissertação de Mestrado, Faculdade de Filosofia, Ciências e Letras de Ribeirão Preto, Universidade de São Paulo, Ribeirão Preto.

No contexto da Oncologia, define-se recidiva como o reaparecimento do câncer após um período de remissão da doença, o que acarreta menor possibilidade de cura e necessidade de reorganização do paciente e de sua família para lidarem com a situação de tratamento. Considerando o elevado nível de ansiedade associado ao diagnóstico de recidiva e o reduzido número de investigações disponíveis na literatura nacional e internacional sobre seus aspectos psicossociais no âmbito da Oncologia Pediátrica, o presente estudo teve como objetivo compreender as vivências de crianças e de seus cuidadores-familiares diante dessa fase do tratamento. Participaram da pesquisa crianças com idades entre cinco e 12 anos incompletos, em tratamento de recidiva de câncer em um centro de referência brasileiro para atenção em onco-hematologia infantil, e seus cuidadores principais. Trata-se de um estudo descritivo e exploratório, com enfoque na abordagem clínico-qualitativa. A fim de atender aos objetivos propostos, foi realizada uma entrevista, guiada por um roteiro semiestruturado, com o familiar responsável pelo cuidado do paciente e duas sessões de aplicação do procedimento de Desenhos-Estórias com a criança. As verbalizações foram audiogravadas mediante o consentimento dos participantes. Os relatos extraídos das entrevistas e as narrativas obtidas nas sessões com as crianças foram transcritos na íntegra e literalmente e, posteriormente, submetidos à análise de conteúdo temática, sendo os conjuntos de Desenhos-Estórias analisados de acordo com as recomendações da literatura. Os resultados mostraram que o diagnóstico de recidiva remeteu os participantes ao período inicial de investigação e diagnóstico, porém com maior mobilização e intensidade afetiva. Emergiram sentimentos de frustração em relação às expectativas de cura, vivências de ameaça e perda de controle diante do adoecer e do prognóstico, favorecendo o confronto com a possibilidade da morte. Tal situação prejudicou a projeção para a temporalidade da cura, de forma a trazer implicações para a atribuição de sentidos da existência. A necessidade de recomeço do tratamento foi acompanhada pela necessidade de reorganização da dinâmica familiar e pelo fortalecimento afetivo para enfrentamento das vicissitudes do cotidiano terapêutico. Observaram-se relações entre as vivências parental e infantil, abrangendo questões como a comunicação e os significados atribuídos ao adoecer. A religiosidade e a busca de senso de controle foram recursos importantes utilizados pelos cuidadores para o enfrentamento das situações desafiadoras, ao passo que as crianças buscaram manter a proximidade afetiva com os cuidadores e fortalecer o sentimento de segurança. Compreender as vivências da criança e de seu cuidador-familiar pode oferecer subsídios para o planejamento de intervenções psicológicas que favoreçam o enfrentamento das peculiaridades da situação de adoecimento introduzidas pelo diagnóstico de recidiva do câncer infantil, contribuindo para a implementação dos cuidados paliativos.

Palavra-chave: neoplasia, recidiva, psicologia da criança, aspectos psicossociais, família, cuidador, cuidados paliativos. 


\begin{abstract}
Arruda, M. N. F. (2013). Relapse of pediatric cancer: the experience of the child and the family caregiver. Master's Thesis, Ribeirão Preto School of Philosophy, Sciences and Languages, University of São Paulo, Ribeirão Preto.
\end{abstract}

In the context of Oncology, relapse is defined as the reappearance of cancer after a remission period of the disease, which entails a lesser possibility of cure and the need for patients and families to get reorganized in order to cope with the treatment situation. In view of the high level of anxiety associated with the relapse diagnosis and the limited number of studies available in Brazilian and international literature about its psychosocial aspects in the Pediatric Oncology context, the aim in this research was to understand the experiences of children and their family caregivers in view of this treatment phase. The research participants were children between five and 12 incomplete years of age, undergoing cancer relapse treatment at a Brazilian referral center for childhood onco-hematology, as well as their primary caregivers. A descriptive and exploratory research with a clinical-qualitative approach was carried out. To achieve the objectives, an interview was held with the relative responsible for patient care, guided by a semistructured script, and two application sessions of the Drawing-And-Story Procedure with the child. The interviews were audio-recorded with the participants' consent. The reports taken from the interviews and the narratives collected during the sessions with the children were fully and literally transcribed and then submitted to thematic content analysis, while the Drawings-Histories were analyzed in accordance with literature recommendations. The results showed that the relapse diagnosis returned the participants to the initial investigation and diagnosis period, but accompanied by greater mobilization and affective intensity. Feelings of frustration emerged with regard to the cure expectations, feelings of threat and loss of control in view of the disease and prognosis, favoring the confrontation with the possibility of death. This situation negatively affected the projected timing of cure, influencing the attribution of meanings to existence. The need to restart the treatment was accompanied by the need to reorganize the family dynamics and the need for affective strengthening to cope with the vicissitudes of daily treatment. Relations between parents and children's experiences were observed, comprising issues like communication and the meanings attributed to the disease. Religiosity and the search for a sense of control were important resources the caregivers use to cope with these challenging situations, while the children attempted to maintain their affective proximity with the caregivers and strengthen their feeling of security. Understanding the experiences of the children and their family caregivers can support the planning of psychological interventions that favor coping with the peculiarities of the disease situation introduced by the relapse diagnosis of child cancer, contributing to the implementation of palliative care.

Key words: neoplasm, relapse, child psychology, psychosocial aspects, family, caregiver, palliative care. 


\section{LISTA DE ILUSTRAÇÕES}

$\begin{array}{ll}\text { Quadro 1. A fazenda } & 81\end{array}$

Quadro 2. A chuva $\quad 82$

$\begin{array}{ll}\text { Quadro 3. A fazenda de Carlos } & 90\end{array}$

Quadro 4. O castelo de Sabrina 92

Quadro 5. O cowboy Woody 93

$\begin{array}{ll}\text { Quadro 6. A história do peixe } & 102\end{array}$

$\begin{array}{ll}\text { Quadro 7. Sem título } & 103\end{array}$

Quadro 8. A ponte do amor 112

$\begin{array}{ll}\text { Quadro 9. O mundo encantado de Marina } & 114\end{array}$

$\begin{array}{ll}\text { Quadro 10. A gosma preguiçosa } & 117\end{array}$

Quadro 11. O pé doente 119

$\begin{array}{ll}\text { Quadro 12. O encontro do amor } & 120\end{array}$ 


\section{LISTA DE TABELAS}

Tabela 1. Distribuição dos artigos localizados e selecionados na revisão de 32 literatura, segundo as bases indexadoras

Tabela 2. Distribuição de artigos selecionados na revisão de literatura, segundo o ano de publicação

Tabela 3. Características sociodemográficas e clínicas dos participantes

Tabela 4. Distribuição da ocorrência das categorias temáticas por entrevista com os cuidadores-familiares

Tabela 5. Distribuição das categorias temáticas por conjunto de Desenhos-

Estórias realizado com as crianças

Tabela 6. Características clínicas das crianças selecionadas para os estudos de caso 


\section{SUMÁRIO}

RESUMO Xiii

ABSTRACT $\quad$ xiv

LISTA DE ILUSTRAÇÕES XV

LISTA DE TABELAS Xvi

1. PREÂMBULO 21

2. ANTECEDENTES DA LITERATURA 23

2.1 Câncer infantil: Epidemiologia e aspectos da atenção em saúde 23

2.2 Aspectos psicológicos do câncer infantil 25

2.3 A questão da recidiva: do impacto ao recomeço 29

3. MARCO TEÓRICO-CONCEITUAL 40

4. DELIMITAÇÃO DO PROBLEMA DE INVESTIGAÇÃO 44

4.1 Objetivo geral 46

4.2 Objetivos específicos 46

5. MÉTODO

5.1 Contextualização metodológica $\quad 47$

5.2 Local do estudo $\quad 48$

$\begin{array}{ll}5.3 \text { Participantes } & 49\end{array}$

5.4 Instrumentos $\quad 50$

$\begin{array}{lr}5.4 .1 \text { Entrevista } & 50\end{array}$

$\begin{array}{ll}\text { 5.4.2 Procedimento de Desenhos-Estórias } & 50\end{array}$

5.5 Procedimentos $\quad 52$

5.5.1 Coleta de dados

5.5.2 Análise de dados $\quad 53$

6. CUIDADOS ÉTICOS 55

7. RESULTADOS E DISCUSSÃO 56

7.1 Pré-análise $\quad 57$

7.1.1 Vivências dos cuidadores-familiares $\quad 57$

7.1.1.1Vivências emocionais no percurso diagnóstico 57

7.1.1.2 Repercussões psicológicas do diagnóstico oncológico 58

7.1.1.3 Dificuldades advindas do tratamento $\quad 59$

7.1.1.4 Experiências compartilhadas com outras crianças em tratamento $\quad 61$

7.1.1.5 Recidiva 61 
7.1.1.6 Comunicação com a criança sobre diagnóstico e tratamento

7.1.1.7 Implicações para a organização familiar 63

7.1.1.8 Repercussões na relação conjugal 64

7.1.1.9 Aspectos emocionais do irmão saudável 64

7.1.1.10 Fé como estratégia de enfrentamento 64

7.1.1.11 Apoio familiar como estratégia de enfrentamento 65

7.1.1.12 Apoio social como estratégia de enfrentamento 65

7.1.1.13 A percepção do enfrentamento infantil como estratégia de 66 enfrentamento

7.1.1.14 Desenvolvimento do senso de potência como estratégia de 66 enfrentamento

7.1.1.15 Confiança na instituição hospitalar como estratégia de 67 enfrentamento

7.1.2 Vivências das crianças em tratamento da recidiva oncológica

$\begin{array}{ll}\text { 7.1.2.1 Percepção de ameaças } & 67\end{array}$

7.1.2.2 Vulnerabilidade e senso de desproteção 68

7.1.2.3 Percepção de fragilidade no Outro $\quad 69$

7.1.2.4 Relação entre o bem e o mal $\quad 70$

$\begin{array}{ll}\text { 7.1.2.5 Despersonalização } & 70\end{array}$

$\begin{array}{ll}\text { 7.1.2.6 Busca de proteção } & 70\end{array}$

$\begin{array}{ll}\text { 7.1.2.7 Busca por relacionamentos afetivos } & 71\end{array}$

7.1.2.8 Percepção de restrição $\quad 72$

$\begin{array}{ll}\text { 7.1.2.9 Perdas ao longo da vida } & 72\end{array}$

7.1.2.10 Autoestima $\quad 72$

7.1.2.11 Percepção de recursos de enfrentamento 72

7.1.2.12 Projeção de situações de crescimento e conforto emocional 73

$\begin{array}{ll}7.2 \text { Os encontros com as crianças e seus cuidadores-familiares } & 73\end{array}$

$\begin{array}{ll}\text { 7.2.1 O encontro com Pablo e seus pais } & 74\end{array}$

$\begin{array}{ll}\text { 7.2.1.1 A entrevista e suas categorias temáticas } & 75\end{array}$

7.2.1.1.1 Repercussões psicológicas do diagnóstico oncológico 75

7.2.1.1.2 Dificuldades advindas do tratamento 76

7.2.1.1.3 Experiências compartilhadas com outras crianças em $\quad 76$ tratamento

7.2.1.1.4 Recidiva: ressignificações e relação com a morte $\quad 77$

7.2.1.1.5 Comunicação com a criança sobre diagnóstico e tratamento 78

7.2.1.1.6 Repercussões familiares: organização, relação conjugal e 79 
aspectos emocionais da irmã saudável

7.2.1.1.7 Estratégias de enfrentamento

7.2.1.2 As sessões do procedimento de Desenhos-Estórias e temas 81 emergentes

7.2.1.2.1 A fazenda

7.2.1.2.2 A chuva 82

7.2.1.3 Síntese compreensiva da díade 84

7.2.2 O encontro com Gabriel e sua mãe 85

7.2.2.1 A entrevista e suas categorias temáticas 86

7.2.2.1.1 Vivências emocionais no percurso diagnóstico e repercussões psicológicas do diagnóstico oncológico

7.2.2.1.2 Dificuldades advindas do tratamento

7.2.2.1.3 Recidiva: frustração de expectativas e repercussão emocional 87

7.2.2.1.4 Comunicação com a criança sobre diagnóstico e tratamento 88

7.2.2.1.5 Repercussões familiares: organização e aspectos emocionais do irmão saudável

7.2.2.1.6 Estratégias de enfrentamento

89

7.2.2.2 As sessões do procedimento de Desenhos-Estórias e temas emergentes

7.2.2.2.1 A fazenda de Carlos

89

7.2.2.2.2 O castelo de Sabrina 90

7.2.2.2.3 O cowboy Woody 91

7.2.2.3 Síntese compreensiva da díade 93

7.2.3 O encontro com Renata e seu pai 94

7.2.3.1 A entrevista e suas categorias temáticas 95

7.2.3.1.1 Vivências emocionais no percurso diagnóstico e repercussões psicológicas do diagnóstico oncológico

7.2.3.1.2 Dificuldades advindas do tratamento 96

7.2.3.1.3 Recidiva: do impacto à incerteza 98

7.2.3.1.4 Comunicação com a criança sobre diagnóstico e tratamento 98

7.2.3.1.5 Repercussões familiares: organização e relação conjugal 99

7.2.3.1.6 Estratégias de enfrentamento 100

7.2.3.2 As sessões do procedimento de Desenhos-Estórias e temas 101 emergentes

7.2.3.2.1 A história do peixe 101

7.2.3.2.2 Sem título 102

7.2.3.3 Síntese compreensiva da díade 104 
7.2.4 O encontro com Valentim e sua mãe

7.2.4.1 A entrevista e suas categorias temáticas 106

7.2.4.1.1 Repercussões psicológicas do diagnóstico oncológico e 106 dificuldades advindas do tratamento

7.2.4.1.2 Recidiva: frustração e a escolha pelo tratamento 107

7.2.4.1.3 Comunicação com a criança sobre diagnóstico e tratamento 108

7.2.4.1.4 Repercussões familiares: organização e relação conjugal 109

$\begin{array}{ll}\text { 7.2.4.1.5 Estratégias de enfrentamento } & 110\end{array}$

7.2.4.2 As sessões do procedimento de Desenhos-Estórias e temas 111 emergentes

7.2.4.2.1 A ponte do amor 111

7.2.4.2.2 O mundo encantado de Marina 114

7.2.4.2.3 A gosma preguiçosa 116

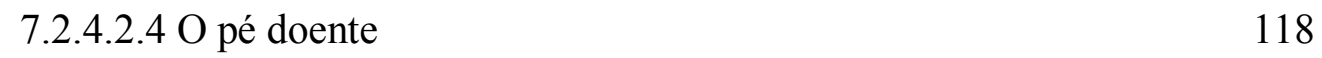

$\begin{array}{ll}\text { 7.2.4.2.5 O encontro do amor } & 120\end{array}$

7.2.4.3 Síntese compreensiva da díade $\quad 122$

7.3 Reflexões sobre a experiência familiar e infantil diante da recidiva em 123 Oncologia Pediátrica

7.3.1 Aproximação com as vivências dos cuidadores-familiares 123

$\begin{array}{ll}\text { 7.3.1.1 Senso de ausência de controle } & 124\end{array}$

$\begin{array}{ll}\text { 7.3.1.2 Percepção de ameaças } & 126\end{array}$

7.3.3 Recomeço: ressignificando as possibilidades de cuidado $\quad 127$

$\begin{array}{ll}\text { 7.3.2 Aproximação com as vivências das crianças } & 129\end{array}$

7.3.2.1 Percepção de ameaças 129

7.3.2.2 Busca por proteção e afeto 131

7.3.3 Aproximação com as vivências na relação criança-cuidador $\quad 132$

7.3.3.1 Vivência compartilhada ao longo do tratamento 132

7.3.3.2 A questão da comunicação 133

8. CONSIDERAÇÕES FINAIS 136

$\begin{array}{ll}\text { REFERENNCIAS } & 138\end{array}$

ANEXOS E APÊNDICES

Anexo A. Aprovação do projeto pelo Comitê de Ética em Pesquisa

Apêndice A. Roteiro de entrevista semiestruturada

Apêndice B. Termo de Consentimento Livre e Esclarecido 


\section{PREÂMBULO}

Discorrer sobre minha escolha pelo tema desta investigação implica em retomar os percursos de minhas escolhas, desde o curso de graduação. O contato com a Psicologia Hospitalar, sua rotina e possibilidades de atuação, em uma entrevista realizada ainda nos tempos de cursinho pré-vestibular, fortaleceram minha decisão pelo curso de Psicologia e guiaram minha formação profissional, pelos efeitos de encantamento que produziram e ainda produzem em mim. Ao longo do curso de graduação, me envolvi em atividades voluntárias, estágios profissionalizantes e colaborações científicas, de forma a me aproximar do contexto hospitalar e instrumentalizar-me para a atuação na área. No contexto hospitalar, cada clínica me confrontava com uma nova realidade e impunha desafios para pensar a atuação. Cada paciente e familiar que acompanhava permitia-me o contato com sua história, vivências peculiares e reorganização frente às mudanças trazidas pelo adoecer. Meu primeiro contato com pacientes oncológicos aconteceu no início do quarto ano da graduação, no estágio curricular profissionalizante que realizei na Unidade de Transplante de Medula Óssea do Hospital das Clínicas da Faculdade de Medicina de Ribeirão Preto da Universidade de São Paulo, uma experiência intensa e apaixonante, sob a supervisão da Dra. Érika Arantes de Oliveira-Cardoso, psicóloga do Laboratório de Ensino e Pesquisa em Psicologia da Saúde LEPPS.

No ano seguinte, realizei estágio profissionalizante no serviço de Oncologia Pediátrica do mesmo hospital, sob supervisão da psicóloga Dra. Leandra Rossi que me apresentou à Psicologia Fenomenológica. A experiência de acompanhar as crianças e suas famílias revestiu-se de um significado especial para mim, devido à confiança e entrega que impunha. Foi também surpreendente perceber, na época, os recursos psíquicos que essas pessoas vulnerabilizadas mostravam a cada etapa do tratamento. Nesse serviço, tive a oportunidade de acompanhar o adoecer e o processo de morrer de um paciente, experiência marcante e envolta de intensos sentimentos. O contato direto da família com o período de cuidados paliativos exclusivos e a iminência da morte não me deixaram dúvidas quanto a ser aquele o local em que desejava me enveredar em minha atuação profissional.

Inicialmente, busquei minha formação teórico-prática por meio do Programa de Aprimoramento Profissional e Especialização Lato Sensu em "Oncologia e Psicologia", sob supervisão da psicóloga Dra. Elisa Maria Perina, oferecido pela Universidade Estadual de Campinas - UNICAMP, com apoio financeiro da Fundação do Desenvolvimento 
Administrativo - FUNDAP. A necessidade de realizar um trabalho de conclusão do curso favoreceu que eu ampliasse meu olhar para os questionamentos acerca do cotidiano da prática em Oncologia Pediátrica. Considerando a definição do início das ações específicas de cuidados paliativos, adotada naquela instituição hospitalar, no momento do diagnóstico da recidiva, deparei-me com questionamentos acerca das vivências emocionais das crianças nesse período de tratamento, suas necessidades e possibilidades de cuidado. Revivia minha experiência na pesquisa de iniciação científica, sob orientação da Profa. Dra. Lucy Leal MeloSilva, deselvolvida no âmbito da Avaliação de Serviços em Orientação Profissional, que ofereceu-me sólida formação científica e fez com que a qualidade da intervenção fosse um questionamento constante em minhas experiências profissionais, inclusive na atenção às crianças em tratamento de recidiva oncológica. Compartilhei essa minha inquietação com a supervisora institucional, Dra. Elisa Perina, e meu orientador, Prof. Dr. Manoel Antônio dos Santos, que abraçaram a causa e acompanharam o processo de construção deste projeto, permitindo que o estudo prosperasse, incentivando-me a embarcar nesse novo desafio.

$\mathrm{Na}$ introdução desta Dissertação de Mestrado foram apresentados os antecedentes da literatura, no que se refere ao câncer infantil e a seu impacto psicossocial, a fim de oferecer um panorama geral sobre o tema e circunscrever os contornos do objeto de investigação. Nesse momento, foi apresentada uma revisão integrativa de literatura sobre a perspectiva das crianças e dos seus familiares diante da recidiva da doença, mapeando o estado da arte, bem como as possibilidades e lacunas existentes. Definiu-se a Fenomenologia, discorrendo brevemente sobre seu percurso histórico a se entrelaçar com o campo da saúde, a fim de oferecer fundamentação teórica que permitisse lançar um olhar compreensivo ao fenômeno investigado.

O presente estudo teve como objetivo compreender as vivências das crianças e seus familiares nesse momento delicado do tratamento que se inicia com o diagnóstico da recorrência do câncer. Em seguida, foram elencados os critérios de inclusão e exclusão dos participantes, assim como os instrumentos e os procedimentos de coleta e análise dos dados, destacando os cuidados éticos assumidos pela pesquisadora. Foram apresentados os resultados e discussão, buscando apresentar a vivência das crianças, dos cuidadores-familiares e das díades, na dupla forma de análise vertical e horizontal, seguidos pelas considerações finais. Por fim, os instrumentos utilizados e os documentos legais necessários para a realização deste estudo foram disponibilizados. 


\section{ANTECEDENTES DA LITERATURA}

2.1 Câncer infantil: Epidemiologia e aspectos da atenção em saúde

Denomina-se câncer um conjunto de doenças nas quais há descontrole do crescimento e multiplicação desordenada de células, podendo acometer diversas partes do corpo (Ministério da Saúde, 2008). Na criança, o câncer é uma doença rara, principalmente se comparada aos tumores em adultos, correspondendo entre $1 \%$ e $3 \%$ das neoplasias malignas em populações gerais (Ministério da Saúde, 2011).

O câncer pediátrico apresenta especificidades no que se refere à etiologia, aos locais primários, aos sinais e ao tratamento clínico, devendo ser estudado separadamente da neoplasia em outras faixas etárias. Em crianças, as células cancerosas se originam de células embrionárias primitivas, o que, somado às características desta fase de desenvolvimento, faz com que sua multiplicação ocorra de forma mais rápida do que ocorre no adulto, com períodos de latência menores e mais invasivos (Hospital do Câncer, 2003).

A fim de conhecer a epidemiologia do câncer infantil, o Instituto Nacional do Câncer (INCA) sistematizou dados sobre sua incidência e mortalidade, por meio dos registros de base populacional sobre novos casos da doença e de óbitos, além da atenção a estudos da sobrevida, por meio de registros populacionais, hospitalares e estudos clínicos controlados, favorecendo um olhar crítico sobre a situação atual da doença e indicadores do acesso ao tratamento (Ministério da Saúde, 2008).

No Estado de São Paulo, a Fundação Oncocentro de São Paulo reuniu informações sobre a incidência entre 0 e 18 anos, no período de 2000 a 2008. Totalizaram 8.768 casos novos, sendo os tipos mais frequentes as Leucemias $(25,7 \%)$, os Linfomas $(16,3 \%)$ e os tumores do Sistema Nervoso Central (12,8\%) (Ministério da Saúde, 2008). No que se refere à estimativa de incidência do câncer no Brasil para o biênio 2012-2013 (Ministério da Saúde, 2011), a projeção para as neoplasias pediátricas mais frequentes se manteve. Outras neoplasias comuns na infância são: Neuroblastoma, Tumor de Wilms, Retinoblastoma, Tumor germinativo, Osteossarcoma e Sarcomas, porém com menores taxas de incidência.

No Brasil, o câncer é considerado um problema de saúde pública e representa a segunda causa de mortalidade entre crianças e adolescentes de 1 a 19 anos, para todas as regiões do país. Cabe ressaltar que se trata, atualmente, da primeira causa de morte por doença, o que reforça a necessidade de mais estudos e o aprimoramento dos serviços de 
saúde, para responder às necessidades da atenção oncológica no Sistema Único de Saúde (Ministério da Saúde, 2008). A literatura apontou para a redução discreta da mortalidade por câncer no país, entre 1979 e 2005, entretanto, nos países desenvolvidos, os índices tiveram redução importante, principalmente para as Leucemias, Linfomas e Tumores Sólidos (Ministério da Saúde, 2008).

No que tange à sobrevida, os estudiosos ressaltaram a importância do diagnóstico precoce e, consequente, tratamento oportuno. Nesse sentido, preconizam ações educativas à população geral, a fim de favorecer o reconhecimento precoce de sinais e sintomas para a busca de assistência especializada, além do investimento em serviços de saúde e treinamento, com vistas ao diagnóstico e encaminhamento eficaz. O atraso no diagnóstico, o encaminhamento para tratamento apenas em fases avançadas da doença e o próprio acesso desigual às tecnologias diagnósticas no país podem trazer implicações significativas para a resposta ao tratamento e a possibilidades terapêuticas (Rodrigues \& Camargo, 2003).

Com o avanço das tecnologias médicas, os métodos de diagnóstico precoce e de tratamento do câncer infantil foram aprimorados, e a possibilidade de cura hoje é uma realidade (Kohlsdorf \& Costa Junior, 2011; Camargo, 2003). Cabe ressaltar que a avaliação do prognóstico é composta por diversos fatores (Ministério da Saúde, 2008), dentre eles: (1) características da criança: sexo, idade, raça, comorbidades, aspectos socioeconômicos; (2) características do tumor: local primário, estadiamento, morfologia e biologia; (3) características do sistema de saúde: desenvolvimento de ações de rastreamento, recursos para diagnóstico e tratamento e qualidade do tratamento.

O tratamento oncológico é iniciado a partir da definição diagnóstica, implementada por meio de exames laboratoriais, clínicos e estudo de imagens. Conforme os protocolos para o tratamento específico do tipo tumoral, os centros especializados para atenção ao câncer podem lançar mão das modalidades de tratamento, a saber: quimioterapia, cirurgia e radioterapia, atentos às respostas dos pacientes às terapêuticas e necessidades de manejo identificadas (Hospital do Câncer, 2003; Ministério da Saúde, 2008).

O INCA destaca, ainda, a importância de ações específicas do setor saúde para o alcance de melhores resultados, por meio da maior compreensão sobre os aspectos genéticos e as influências dos hábitos de vida envolvidos na epidemiologia do câncer pediátrico que ainda são pouco esclarecidos, além da organização da rede de atenção em saúde com gestão competente e o desenvolvimento das estratégias de diagnóstico e tratamento oportunos (Ministério da Saúde, 2011). 


\subsection{Aspectos psicológicos do câncer infantil}

O tratamento do câncer infantil é prolongado e implica no contato frequente com o hospital, consultas ambulatoriais, internações, exposição a procedimentos invasivos, além de questões de autoimagem e de alterações das relações interpessoais, o que afeta o desenvolvimento físico, cognitivo, emocional e social do paciente, além de trazer implicações imediatas e a longo prazo para o sistema familiar (Kohlsdorf \& Costa Junior, 2012; Valle, 1994). O adoecimento exige a apropriação de cuidados e adaptação aos novos contextos e seus desafios, acompanhados de sentimentos conflituosos diante da ruptura experimentada pelo paciente e sua família. Desse modo, o tratamento não pode se restringir à busca da cura e passou a atentar também para a recuperação total do estado de saúde do paciente, o que envolve seus aspectos físicos, psicológicos, sociais e espirituais (Menezes, Passareli, Drude, Santos, \& Valle, 2007; Motta, Enumo, \& Ferrao, 2006).

Apesar dos esforços e avanços recentes da medicina, o percurso de atenção oncológica continua permeado por dificuldades e proporciona à unidade de cuidado importante estresse e vivências de ameaça. O momento do diagnóstico do câncer é vivenciado sob o estigma da "doença fatal", ainda frequente no imaginário coletivo, o que impõe o confronto com a possibilidade de fracasso terapêutico e, por conseguinte, com a fragilização da esperança de cura e o vislumbre da possível perda do filho, dando início ao processo de luto antecipatório (Menezes et al., 2007; Parkes, 1998).

Em um estudo comparativo sobre a vivência do luto antecipatório, realizado com 1.040 pais provenientes da Jordânia, poucos pais de crianças com câncer referiram estar em paz consigo mesmos e com sua situação de vida (Al-Gamal \& Long, 2010). Os autores destacaram que tais sintomas foram mais intensos na vivência de pais de crianças com diagnóstico recente do que daquelas que realizavam o tratamento havia pelo menos seis meses. Defenderam ações de atenção à saúde que envolvam a discussão sobre os sentimentos suscitados pelo adoecimento do filho e suas possibilidades de ação e enfrentamento dos desafios impostos. Segundo Lopes e Valle (2001), o período de definição diagnóstica provoca uma desestruturação da unidade familiar e, para sua adaptação ao contexto de tratamento, exige a apropriação dos conhecimentos e dos cuidados. O paciente, por sua vez, pode vivenciar alterações no estado de humor, sentimentos mistos de raiva, desespero e esperança de cura.

A comunicação diagnóstica e das situações de evolução do quadro clínico do paciente, como a progressão da doença e ausência de possibilidades terapêuticas, enquadra-se nas 
situações de comunicação de notícias difíceis em oncologia, merecendo atenção e treinamento da equipe de saúde. Além da organização das informações para a transmissão efetiva da realidade, torna-se essencial avaliar a compreensão do paciente e/ou familiar e seus pedidos sobre informação, além de dar conta da escuta e acolhimento dos aspectos emocionais envolvidos. Por fim, a literatura defendeu a importância de finalizar a comunicação com a proposta de um plano de cuidados, a fim de auxiliar na organização para o enfrentamento e a elaboração das informações (Ministério da Saúde, 2010). A questão da comunicação com a criança suscita com frequência reflexões acerca das possibilidades de compreensão e apropriação das informações, sendo importante a adequação da linguagem, com estratégias de comunicação apropriadas à faixa etária, tendo a equipe de saúde papel importante nessa mediação (Ministério da Saúde, 2010). A literatura sugere que a comunicação clara e aberta sobre a temática favoreceria que o paciente deixasse a posição de espectador, de forma a promover melhores resultados no enfrentamento e cooperação infantil, além de trazer ganhos ao suporte parental (Hildenbrand, Clawson, Alderfer, \& Marsac, 2011; Montoya-Juárez et al., 2012).

Após a elaboração inicial das emoções, as atenções voltam-se para a condição clínica e possibilidades terapêuticas, favorecendo a busca de estratégias para o enfrentamento da ameaça (Valle, 1994). Ao longo do tratamento, emergem a necessidade de lidar com a dor, o medo do desconhecido e a incerteza frente ao sucesso das medidas terapêuticas, além dos efeitos colaterais que, somados ao afastamento social, constituem as principais marcas do sofrimento infantil, na perspectiva dos pais e profissionais de saúde (Montoya-Juárez et al., 2012). Nesse cenário, o temor da morte e a percepção do sofrimento são os eventos que geram maiores níveis de estresse nos cuidadores (Alves, Guirardello, \& Kurashima, 2013). Assim, as consequências percebidas no processo de adoecimento e tratamento não são restritas ao campo da saúde, trazendo também implicações para a vivência social, tanto pelo estigma da doença e isolamento necessário para o tratamento como pela perda de controle sobre o corpo e da autonomia que acarretam (Li, Chung, \& Chiu, 2010; Araujo, 2006; Carvalho, 2002). O sentimento de insegurança permeia o período de tratamento e os medos, fantasias e sofrimentos do paciente são compartilhados pela família que acompanha a criança nas diferentes situações e experimenta rearranjos na dinâmica e nos papéis de seus membros (Cardoso, 2007; Oliveira-Cardoso \& Santos, 2008; Pérez Cárdenas \& Rodríguez Herrera, 2006).

Compreende-se a família como um grupo de pessoas que apresenta uma organização social, considerando aspectos relacionados à reprodução, aliança, descendência e 
consanguinidade (Durham, 1983), abrangendo as ressonâncias sócio-históricas e culturais do contexto em que se insere (Durham, 1984). Ao longo da história, a família tem ocupado uma posição de centralidade no desenvolvimento infantil, recebendo atenção em estudos sobre psicopatologia e desenvolvimento emocional. Destacou-se o processo de socialização e aquisição de comportamentos e valores adequados para a vivência em determinada sociedade, somados ao favorecimento do exercício do posicionamento em diferentes situações, percepção e expressão emocional que contribuem com o processo de individuação e construção da identidade (Scott, 2001), podendo ser estendidos à compreensão e relação estabelecida com as questões de vida e morte (Barbosa, Neme, \& Melchiori, 2011).

Tendo em vista a dinamicidade da instituição familiar, destacam-se os séculos XX e XXI como cenário de mudanças e transformações radicais nos âmbitos cultural, econômico, político e social, que culminaram em transformações nos papéis parentais e de provimento de cuidados com a prole (Scott, 2001). Os estudos sobre os papéis parentais destacaram sua construção cultural, recebendo influências das posições ocupadas pelo homem e pela mulher na sociedade e em relação aos filhos (Gilligan, 1982; Romanelli, 2003; Thorne, 1992). Gilligan (1992), ao discorrer sobre o papel da mulher na família, a posiciona em um espaço relacionado à alimentação, ao cuidado, ao companheirismo, além de atuar na mediação dos relacionamentos interpessoais, tendo o afeto lugar privilegiado em suas relações. Já a paternagem, segundo Romanelli (2003), desenvolve-se no modelo de dedicação ao trabalho e sustento familiar, sendo o cuidado direcionado ao desempenho profissional e à reprodução social da família. Assim, o lugar de cuidado ocupado pela mãe parece refletir aspectos da representação social da mulher, fundamental para a manutenção dos laços de parentesco, principalmente em situações de crise (Romanelli, 2003). Na contemporaneidade, em concordância com as mudanças culturais, sociais e econômicas destacadas anteriormente, percebe-se uma alteração no que se refere à divisão entre pai e mãe nos cuidados com o filho, que deixou de ser primordialmente tarefa feminina e tornou-se compartilhada (Amazonas \& Braga, 2006). Trata-se de uma mudança gradual, mediada pelos novos valores sociais e maior permissão da participação paterna no desempenho de funções de cuidado no contexto familiar.

No contexto de adoecimento, a atenção ao impacto nas relações familiares se mostrou importante ferramenta no auxílio à adaptação infantil e ao enfrentamento do estresse no processo saúde-doença (Castro \& Piccinini, 2002). Assim, a família ocupa lugar de mediadora da relação criança-doença, sendo essencial considerar as influências recíprocas entre a atitude dos cuidadores e da criança frente à doença, uma vez que se instaura a necessidade familiar de 
cuidado à criança, mas também cuidado às emoções de seus membros (Campos, 2007). Nesse sentido, torna-se importante oferecer espaço de escuta especializada também aos familiares, para compreender seu histórico de experiências, suas crenças e valores, identificando a rede social de apoio disponível, a fim de planejar a intervenção e contribuir para o enfrentamento do processo de adoecimento e tratamento (Araujo, 2006; Campos, Rodrigues, Machado, \& Alvarez, 2007; Lopes \& Valle, 2001; Oliveira, Voltarelli, Santos, \& Mastropietro, 2005).

Nesse contexto, estudos identificaram níveis de estresse, sobrecarga e depressão nos pais, com alterações no padrão alimentar, sono-vigília, laboral e socialização (Alves et al., 2013; Klassen et al., 2007; Kohlsdorf \& Costa Junior, 2012; Moreira \& Angelo, 2008), apresentando piores índices de qualidade de vida, conforme a gravidade do estado clínico infantil e menor tempo decorrido desde o diagnóstico (Klassen et al., 2008). O relacionamento conjugal dos pais também pareceu prejudicado em alguns momentos, devido ao estresse vivenciado e ao maior investimento afetivo no cuidado infantil, em detrimento da relação do casal. No entanto, a literatura também apontou para possibilidades de fortalecimento e ganhos na união conjugal, diante da situação de crise, notadamente quando estava presente o apoio psicossocial (Beltrão, Vasconcelos, Pontes, \& Albuquerque, 2007; Kohlsdorf \& Costa Junior, 2012; Lavee \& Mey-Dan, 2003; Steffen \& Castoldi, 2006).

O câncer infantil pareceu trazer implicações também para a reflexão dos pais a respeito da educação dos filhos e manejo comportamental, desde aspectos da dieta familiar, até considerações sobre a flexibilização de regras e limites educacionais, comuns em doenças crônicas infantis, como atitudes compensatórias dos sofrimentos advindos do tratamento (Chao, Chen, Wang, Wu, \& Yeh, 2003). Considerando a questão dos irmãos saudáveis, a literatura atentou para questões relacionadas à vivência emocional, pontuando sobre a queda do rendimento escolar, sentimentos de ciúmes e rejeição pelo cuidado intensivo ao paciente, apresentação de sintomas psicossomáticos e reações de tristeza, preocupação e ansiedade, defendendo a necessidade de atenção às questões emocionais para uma melhor adaptação familiar ao processo de adoecimento e tratamento (Kohlsdorf \& Costa Junior, 2012; Prchal, Graf, Bergstraesser, \& Landolt, 2012).

Pacientes e familiares utilizam diferentes estratégias de enfrentamento, a fim de se reorganizarem diante das mudanças suscitadas pelo adoecimento infantil, sendo necessário o confronto com a realidade, o manejo dos tratamentos invasivos, a ressignificação da experiência, o reconhecimento da situação e o ajustamento a ela (Yeh, 2003). Destacaram-se a apropriação das informações médicas, enquanto busca de senso de controle da situação 
ameaçadora e organização para o enfrentamento; o apoio familiar, nuclear e ampliado, com relatos de auxílio emocional, nas rotinas diárias e no aspecto financeiro; o suporte social, abrangendo a rede de apoio de trabalho, relacionamentos de amizades anteriores ao adoecimento e estabelecidos no local de tratamento; a religiosidade, promovendo facilitação da compreensão do adoecer e preservação da esperança diante das incertezas (Beltrão et al., 2007; Gibbins, Steinhardt, \& Beinart, 2012; Paiva, 2007; Paulo, Galvão, Rocha, \& Nascimento, 2008). No caso das crianças, além das estratégias anteriores, o brincar emergiu como possibilidade de favorecer o contato e a expressão emocional (Hildenbrand et al., 2011). Destacou-se, também, o papel da equipe de saúde, em especial a atenção em saúde mental, no sentido de contribuir para a adaptação e ajustamento à situação de diagnóstico e ao tratamento oncológico (Gibbins et al., 2012; Kohlsdorf \& Costa Junior, 2008).

\subsection{A questão da recidiva: do impacto ao recomeço}

Define-se recidiva como o reaparecimento do câncer no local primário, próximo à região do local inicial e/ou em outras partes do corpo ou metastático (National Cancer Institute, n.d.). A noção de que o tratamento instituído não foi eficaz e de que há uma possível redução das chances de cura, além de implicar no retorno à rotina hospitalar e à situação de adoecimento, gera impacto na vivência emocional do paciente e de seus familiares, além de tornar necessária a reorganização de seus recursos de enfrentamento (Espíndula, 2001a; Hinds et al., 1996).

O receio frente à possibilidade da ocorrência de recidiva está presente no relato de pacientes e de familiares desde o diagnóstico, perpassando todo o período de tratamento e, também, após o término da terapia (Hinds, Birenbaum, Paulosa, \& Paulosa, 2002), o que acarreta alto nível de estresse para o paciente e seus familiares (Arrais \& Araujo, 1999; De Graves \& Aranda, 2008; Vivar, Canga, Canga, \& Arantzamendi, 2009).

A literatura internacional sobre o tema evidencia uma crescente preocupação com os aspectos psicossociais envolvidos na experiência de recidiva de câncer, notadamente em pacientes adultos (Andersen, Carpenter, Yang, \& Shapiro, 2007; Shim, Shin, Oh, \& Hahm, 2010; Vivar, Whyte, \& McQueen, 2010). Vivar, Whyte e Mcqueen (2010) destacaram que a comunicação da recidiva pareceu remeter os pacientes ao período diagnóstico, no entanto, com maior intensidade nas reações emocionais. A aproximação com a vivência do choque inicial, o "conhecido" do tratamento e a necessidade de recomeço suscitaram sentimentos de frustração, incerteza e desesperança que variaram conforme o período fora de terapia até a 
ocorrência da recaída e a idade do paciente. No contexto do câncer de mama, Yang, Thornton, Shapiro e Andersen (2008) compararam o enfrentamento de mulheres diante do diagnóstico inicial e de recidiva, por meio de avaliações seriadas no período imediato ao diagnóstico, após quatro meses, após oito meses e, por fim, após 12 meses, a fim de determinar o estado de saúde, estresse, humor e qualidade de vida. Demonstraram que, nas semanas que sucediam o diagnóstico, as pacientes apresentavam altos níveis de estresse e sintomas, além de declínio na qualidade de vida. No caso das pacientes em recidiva, perceberam-se poucos ganhos no domínio da função física, após o período de um ano, sugerindo a possibilidade de benefícios com intervenções no âmbito emocional. Outro dado interessante foi de, apesar de terem identificado alterações no humor e dificuldades emocionais nos dois grupos, as pacientes recidivadas relatarem menores índices de ansiedade, confusão e estresse do que aquelas em diagnóstico inicial, o que sugere possíveis benefícios com a experiência adquirida no primeiro tratamento para lidar com o retorno da doença.

Vivar, Canga, Canga e Arantzamendi (2009) realizaram uma revisão sistemática de literatura sobre a vivência da recidiva, sob a perspectiva do paciente e de seus familiares. Destacaram a ameaça da recidiva, ao longo do período fora de terapia, e questões relacionadas ao diagnóstico, a organização para o tratamento e o lidar com as incertezas. A concretização da ameaça, com a recaída da doença, trouxe implicações para diferentes esferas da vida do paciente e impôs a necessidade de reflexão e reorganização familiar. Os autores concluíram que acompanhar tal processo familiar proporciona melhorias para a saúde. Apesar de trazerem contribuições no que se refere ao estresse emocional e ao comprometimento das relações interpessoais e atividades cotidianas, presentes nas duas situações de recidiva, estudos com a população infantil são necessários a fim de melhor compreender e atender a suas demandas (Hinds et al., 2002).

No contexto da Oncologia Pediátrica, as investigações sobre a vivência da recaída continuam escassas, se comparadas à enorme atenção dedicada ao impacto do diagnóstico de câncer e ao enfrentamento da fase terminal (Vivar et al., 2009). A fim de conhecer o estado da arte, foi realizada uma revisão integrativa de literatura que consiste na compilação de estudos referentes a determinado problema de investigação, de forma a possibilitar a análise crítica quanto aos seus objetivos e percurso metodológico, gerando contribuições para a integração do conhecimento e para sua aplicabilidade, com vistas ao desenvolvimento da área em questão (Pompeo, Galvão, \& Rossi, 2009).

Seguindo as orientações da literatura, a elaboração da revisão foi desenvolvida em cinco etapas: formulação do problema norteador, coleta dos dados, avaliação dos dados 
coletados, análise dos dados e apresentação dos resultados (Mendes, Silveira, \& Galvão, 2008).

A formulação da questão norteadora da revisão foi definida a partir do seguinte questionamento: "Qual é o status do conhecimento produzido sobre as vivências do paciente e seus cuidadores diante da recidiva em Oncologia Pediátrica?".

Para a coleta de dados, optou-se pela busca eletrônica de publicações nas bases indexadoras PubMed, LILACS, SciELO, PsycINFO e Cochrane Library, por meio do cruzamento das palavras-chave/descritores: neoplasias / neoplasms / neoplasias; recidiva / recurrence, relapse / recurrencia; recidiva de neoplasia / neoplasm recurrence / recurrencia de neoplasia; criança / child / niño; família / family / familia; pais / parents / padres; psicologia da criança / child psychology / psicología infantil. As buscas nas bases bibliográficas foram realizadas em julho de 2013.

Para delimitação do corpus de análise, realizou-se a leitura atenta do resumo e dos textos das publicações recuperadas na íntegra. Foram definidos como critérios de inclusão: (1) publicação em periódicos indexados nas bases selecionadas; (2) em idioma português, espanhol ou inglês; (3) publicação até julho de 2013, sem limite inferior preestabelecido; (4) artigos recuperados na íntegra; (5) estudo das vivências dos pacientes e/ou seus familiares diante do retorno da doença oncológica infantil. Foram definidos como critérios de exclusão: (1) estudos que focalizassem a vivência da recidiva, no contexto da Oncologia Clínica; (2) estudos sobre avaliação médica da recidiva; (3) estudos com sobreviventes ao câncer infantil, que não focassem a experiência da recidiva; (4) artigos sobre a vivência de outros familiares, que não os cuidadores. Artigos repetidos em mais de uma base foram computados uma única vez.

A revisão de literatura possibilitou o acesso a 552 artigos na base de dados PubMed, 130 estudos na LILACS, 38 publicações na PsycINFO, 255 artigos na Cochrane Library e sete estudos na SciELO. Após aplicar os critérios de inclusão e exclusão, foram selecionados 10 artigos disponíveis na base de dados PubMed, um disponível na LILACS e um na PsycINFO, conforme Tabela 1. A seleção final foi composta por 12 publicações que se mostraram pertinentes aos objetivos propostos. Os principais motivos para a exclusão de artigos foram: o distanciamento do foco que norteia a presente investigação, ou pela atenção à recaída da neoplasia em outras faixas etárias, ou por não abordarem as vivências dos pacientes e seus cuidadores diante da recidiva e, notadamente, por apresentarem estudos médicos sobre a recorrência, seja com foco diagnóstico, prognóstico ou de atualização terapêutica. 
Tabela 1.

Distribuição dos artigos localizados e selecionados na revisão de literatura, segundo as bases indexadoras

\begin{tabular}{ccccc}
\hline Bases de dados & Total de artigos & $\%$ & $\begin{array}{c}\text { Artigos } \\
\text { selecionados }\end{array}$ & $\%$ \\
\hline PubMed & 552 & 56,21 & 10 & 83,33 \\
LILACS & 130 & 13,23 & 1 & 8,33 \\
PsycINFO & 38 & 3,86 & 1 & 8,33 \\
SCIELO & 7 & 0,71 & - & - \\
Cochrane & 255 & 25,96 & - & - \\
Total & 982 & 100 & 12 & 100 \\
\hline
\end{tabular}

Os estudos analisados foram produzidos no período de 1995 a 2013, distribuídos conforme a Tabela 2. Destacaram-se publicações norte-americanas $(41,7 \%, \mathrm{n}=5)$, porém foram encontrados estudos originários do Brasil, Canadá, Reino Unido, Austrália, China, Holanda e Suíça (cada um com 8,33\%, $\mathrm{n}=1$ ). Majoritariamente, foram publicados em inglês $(91,66 \%, \mathrm{n}=11)$, sendo apenas um publicado em português $(8,33 \%, \mathrm{n}=1)$ e nenhum encontrado na língua espanhola. Abrangeram as áreas de Psicologia $(41,67 \%, \mathrm{n}=5)$, de Enfermagem $(41,67 \%, n=5)$, de Saúde Pública $(8,33 \%, n=1)$ e Multiprofissional $(8,33 \%, n$ $=1)$.

Em relação ao delineamento metodológico, 66,67\% $(n=8)$ dos artigos utilizaram metodologia quantitativa, 25\% ( $\mathrm{n}=3)$ eram estudos de abordagem qualitativa, 8,33\% $(\mathrm{n}=1)$ era teórico. Dentre os artigos selecionados, o uso de questionários e de escalas para avaliação e coleta dos dados foi predominante $(66,67 \%, \mathrm{n}=8)$, seguido pelo uso de entrevista $(25 \%, \mathrm{n}=$ 3) e da revisão de literatura para a sistematização das práticas $(8,33 \%, \mathrm{n}=1)$.

Os estudos serão apresentados a seguir, inicialmente abordando a vivência dos cuidadores diante da recidiva em Oncologia Pediátrica e, em seguida, a perspectiva do paciente pediátrico.

Hinds et al. (1996) realizaram um estudo prospectivo nos Estados Unidos, a fim de explorar o processo experimentado pelos pais diante da primeira recaída oncológica de seus filhos e mapear os modos de enfrentamento parental nesse momento de tratamento. Foram acompanhados 33 pais, com realização de entrevistas e análise de registros médicos. Interessante notar que $15 \%$ dos participantes potenciais desistiram da participação, por questões da disponibilidade emocional e de tempo, sugerindo sobre as dificuldades que permeiam o estudo da temática. Discorreram sobre os esforços para superar o impacto inicial da comunicação da recaída e tomar decisões a respeito do tratamento, considerando limites, 
riscos e impotência. Para os pais entrevistados, a possibilidade da morte se contrapunha ao desejo da eficácia do tratamento, com vivências de luto antecipatório. Com o intuito de buscar segurança e de fortalecer o senso de controle, atentavam aos sinais do filho diante do tratamento, apegavam-se à confiança na equipe de saúde e buscavam informações referentes ao processo de tratamento. Os autores destacaram a mediação do ajustamento parental pela equipe de saúde, por meio da comunicação e aspectos afetivos do cuidar, e pela criança, por meio dos sintomas secundários ao tratamento e à evolução da doença.

Tabela 2.

Distribuição de artigos selecionados na revisão de literatura, segundo o ano de publicação

\begin{tabular}{ccc}
\hline Ano & $\begin{array}{c}\text { Número de artigos } \\
\text { selecionados }\end{array}$ & $\%$ \\
\hline 1995 & 1 & 8,3 \\
1996 & 1 & 8,3 \\
1997 & - & - \\
1998 & - & - \\
1999 & - & - \\
2000 & - & - \\
2001 & 2 & 16,7 \\
2002 & 2 & 16,7 \\
2003 & - & - \\
2004 & - & - \\
2005 & - & - \\
2006 & - & - \\
2007 & - & - \\
2008 & 1 & 8,3 \\
2009 & 1 & 8,3 \\
2010 & 1 & 8,3 \\
2011 & 1 & 8,3 \\
2012 & 2 & 16,7 \\
Total & 12 & 100,0 \\
\hline
\end{tabular}

Outra temática abordada foi a percepção da situação clínica do paciente. Sung et al. (2009) avaliaram a prevalência e os preditores do otimismo parental em maus prognósticos de câncer pediátrico de crianças, em um estudo transversal multicêntrico que envolveu cinco cidades canadenses. Foram abordadas 395 famílias de crianças recebendo tratamento quimioterápico, por meio da aplicação de uma escala de 5 pontos sobre o prognóstico infantil, tendo como disparador a pergunta: "Como você pessoalmente avalia a perspectiva de recuperação de seu filho?”. Além disso, os pais responderam a questionários sobre características parentais, medidas de controle e autoestima (National Population Health 
Survey), otimismo (Life Orientation Test - Revised) e religiosidade (Santa Clara Strength of Religious Faith questionnaire). A fim de contrapor os dados, cinco oncologistas pediátricos avaliaram o prognóstico dos pacientes, segundo características da criança e da doença, em uma escala de 3 pontos. Os dados revelaram que 1,5\% dos pais foi pessimista na avaliação, quando os médicos avaliaram o prognóstico como bom. Já quando o prognóstico foi avaliado como ruim pelos médicos, $10,6 \%$ dos pais avaliaram positivamente. Se comparados aos pais de crianças com Leucemia, os pais de crianças com tumores sólidos, cerebrais, recidivados e com grande otimismo mostraram-se mais propensos a ter otimismo ao estimar o prognóstico, quando os médicos avaliaram como mau prognóstico. A avaliação não se mostrou relacionada à disposição parental ao otimismo. De forma semelhante ao proposto por Hinds et al. (1996), Sung et al. (2009) discutiram sobre as implicações da compreensão para o processo de enfrentamento e seu papel no prognóstico do paciente, destacando a importância da atenção à comunicação de informações médicas.

De Graves e Aranda (2008) realizaram um estudo etnográfico na Austrália, com o objetivo de explorar as vivências familiares diante da recidiva infantil, a fim de compreender os comportamentos e emoções e, assim, rever as práticas de cuidado. Foram realizadas quatro entrevistas com 12 famílias, em um período de seis meses e meio a 13 meses. Destacaram a intensa incerteza vivenciada pelos familiares, com oscilação entre a esperança da preservação da vida e a ameaça da morte, trazendo impacto na busca pela cura, nas decisões relativas ao tratamento e em questões do prognóstico. Preparar-se para a perda emergiu como estratégia de enfrentamento e de ganho de senso de controle, assim como a busca de manutenção da normalidade e o foco na vida no momento atual, a hipervigilância e busca de informações, com intuito de buscar segurança e atenuar o medo de nova recidiva. Assim, o ajustamento viria com os ganhos do manejo da incerteza, reforçando a importância de abordá-la na atenção aos familiares diante da recaída da doença. Além disso, os autores defenderam que compreender os medos e as esperanças vivenciadas pelos familiares, diante desse momento do tratamento, pode auxiliar na identificação de desafios e na promoção de comunicações abertas.

Com vistas a combater os altos índices de estresse experimentados ao longo do tratamento, Dunn et al. (2012) buscaram avaliar os sintomas de estresse pós-traumático em mães e pais de crianças e jovens com câncer. Participaram do estudo 191 mães e 95 pais, totalizando 195 famílias de crianças e jovens com câncer, entre 2 e 22 semanas, após o diagnóstico do câncer ou recidiva do diagnóstico inicial. A fim de atender aos objetivos propostos, foram aplicados um questionário sociodemográfico e três escalas para avaliação: a) 
de sintomas de estresse pós-traumático (Impact of Event Scale-Revised), b) de depressão (Beck Depression Inventory II) e c) de ansiedade (Beck Anxiety Inventory), posteriormente cruzados com dados do itinerário terapêutico. Os resultados sugeriram que $41 \%$ das mães e $30 \%$ dos pais obtiveram níveis acima da média no que se referiu aos sintomas de estresse póstraumático, com altos níveis de depressão e ansiedade. No que tange aos pais de crianças e jovens recidivados, houve aumento significativo dos níveis de estresse pós-traumático, se comparados aos pais de crianças e jovens em primeiro tratamento, diferença que não foi identificada nos relatos das mães. Dessa forma, pais e mães relataram sintomas de estresse pós-traumático, durante os primeiros seis meses de tratamento, possivelmente como parte do estresse emocional vivenciado, sendo a recidiva facilitadora de maior nível desses sintomas, o que reforçou os benefícios do acompanhamento psicológico no período.

No contexto chinês, Mu et al. (2001) implementaram um estudo descritivo com o objetivo de examinar o impacto da experiência de estresse em mães, durante do tratamento oncológico infantil. Avaliaram 100 mães, por meio da aplicação das escalas "Parental Perception of Uncertainty Scale", "Sense of Mastery Scale”, "Boundary Ambiguity Scale”, "State-Trait Anxiety Inventory". O senso de controle foi encontrado como mediador entre a incerteza e a ansiedade, sendo a incerteza boa preditora da vivência de ambiguidade. Os dois primeiros meses de tratamento e a incidência da recidiva representaram uma importante experiência para as mães, sendo a incerteza associada à ansiedade e ao estresse emocional. As mães com experiência de recidiva em seus filhos apresentaram diferença significativa na avaliação do senso de potência, apresentando níveis inferiores se comparadas às mães de crianças em remissão da doença. Os autores discutiram a intervenção de enfermagem como favorecedora do senso de controle e da funcionalidade na relação pais-filhos, com vistas à facilitação da lida.

Com base no modelo da incerteza, Lin, Yeh e Mishel (2010) buscaram analisar o impacto da vivência da incerteza na saúde infantil, considerando o nível educacional dos pais e o suporte social percebido. Realizaram um estudo transversal, envolvendo 205 mães e 96 pais de um total de 226 crianças em tratamento oncológico. Foram aplicados o questionário sobre incerteza (Parental Perception of Uncertainty Scale) e crescimento por meio dela (Growth Through Uncertainty Scale), além de instrumentos para avaliação de percepção do suporte social (Parental Coping Strategy Inventory) e do enfrentamento (Parental Coping Strategy Inventory). Somados a esses dados, foi solicitada aos pais a resposta a um questionário sobre informações pessoais próprias e sobre a saúde do filho, associado a uma avaliação funcional (revised Functional Status II). A incerteza parental e a percepção de 
suporte social mostraram-se associadas com o crescimento pessoal por meio da incerteza, mediada pelo enfrentamento. A incerteza mostrou ter impacto negativo na estratégia de enfrentamento como interação com familiares, sendo o suporte social disponível fonte de alívio deste sentimento e de encorajamento. Ao comparar a vivência do crescimento por meio da incerteza em diferentes estágios do tratamento, os autores não identificaram diferença significativa.

Atentas às mães na iminência da perda de um filho por recidiva oncológica, Espíndula e Valle (2002) realizaram um estudo de caso, a fim de compreender a percepção materna e suas formas de enfrentamento diante do tratamento da recidiva oncológica de seu filho, em um hospital terciário brasileiro. Por meio de uma entrevista fenomenológica, identificaram quatro temáticas principais: a) modos de perceber a doença e o tratamento; b) relato da visão da mãe sobre o filho; c) a percepção de si mesma ao enfrentar a recidiva, busca do cuidado ao filho e de explicações para a doença, permeadas pelo medo da morte e pela culpa e; d) modos de a família se relacionar com a criança. As autoras notaram certa dificuldade materna em expressar-se sobre a recidiva do filho, porém defenderam que o compartilhar trouxe benefícios, promovendo alívio de angústias.

Os estudos descritos apresentaram a perspectiva parental diante da recidiva oncológica infantil, abrangendo sua vivência emocional, fatores de estresse e possibilidades de intervenção. Destacaram-se a discussão sobre as ressonâncias psicológicas do diagnóstico da recidiva e a necessidade de tomada de decisão no tratamento, permeadas por altos níveis de sintomas de estresse pós-traumático. A ameaça da morte se contrapunha à esperança da preservação da vida, trazendo sentimentos de incerteza e impotência. Os autores refletiram sobre o papel da equipe de saúde na mediação dos aspectos emocionais e na organização para o enfrentamento da situação de crise.

Dois estudos selecionados optaram pela avaliação conjunta dos pacientes e seus cuidadores, considerando a unidade de cuidado no contexto da recidiva oncológica em pediatria.

O primeiro deles buscou investigar a emergência de sintomas de estresse póstraumático em sobreviventes de câncer cerebral e seus pais (Bruce, Gumley, Isham, Fearon, \& Phipps, 2011). O estudo abrangeu 54 crianças, entre oito e 16 anos, e seus pais, no Reino Unido. Os participantes responderam a questionários para avaliação da relacão pais-filho (The Parent-Child Interaction Questionnaire - Revised, versão para pais e para a criança), atenção aos estilos de enfrentamento (Miller Behavioural Style Scale - para os pais; The Children's Behavioural Style Scale - para as crianças), bem como de sintomas de estresse pós-traumático 
(The Impact of Event Scale - Revised). Além disso, foram organizadas informações sobre a doença e o tratamento. Os resultados apontaram para 35\% dos sobreviventes com severos níveis de sintomas de estresse pós-traumático, comparados à presença em 15\% dos pais. Para os sobreviventes, os níveis de sintomas de estresse pós-traumático estiveram significativamente relacionados ao número de dias de hospitalização e à resolução de conflitos nas relações com os pais. Já para os pais, estiveram associados ao número de recidivas da doença e à resolução de conflitos. Os autores defenderam que os pais teriam maior risco de estresse orientado para a incerteza do futuro pela experiência do câncer do que as crianças sobreviventes, fortalecendo a importância de atenção aos cuidadores nesse contexto.

Já no segundo artigo, Hinds et al. (2002) desenvolveram um estudo transcultural, em uma parceria entre os Estados Unidos da América e o Brasil, para delimitar orientações para auxiliar pacientes e seus familiares a enfrentarem a recidiva oncológica pediátrica. Notaram uma reação inicial de choque ao diagnóstico da recidiva, semelhante ao processo de luto (Kubler-Ross, 1998; Parkes, 1998), com expressões de descrença na veracidade da confirmação e esforços no sentido de negar tal realidade, inclusive na forma de recusa de um novo tratamento. Foi frequente o relato de evitar a expressão aberta de sentimentos, como forma de proteção ao outro familiar. Os autores sugeriram que a equipe seja educada em relação a tais processos psicológicos e intervenções possíveis, como oferecer espaço de escuta individualizado e atuar como mediador na relação paciente-familiar-equipe. No momento da comunicação diagnóstica, os autores destacaram a relevância de se apresentarem as opções de tratamento, como estratégia para fortalecer o cuidador-familiar e instilar esperança nesse momento crítico. Enquanto nos Estados Unidos da América os pacientes valorizaram o contato gradual com o tratamento como favorecedor do enfrentamento, no Brasil enfatizaram a esperança de cura, a partir do conhecimento de casos de sucesso. Além disso, destacaram a ressonância tanto da percepção sobre o prognóstico, como do apoio da família, para o enfrentamento do paciente no contexto brasileiro, reforçando a importância da assistência estendida aos familiares (Hinds et al., 2002).

Os estudos apresentados retomaram a discussão sobre a incidência de sintomas de estresse pós-traumático e incerteza, tanto para os pacientes, como para seus pais. Bruce et al. (2011) identificaram maior risco emocional nos cuidadores e, em consonância ao proposto por Hinds et al. (2002), fortaleceram a sugestão do seguimento psicossocial aos cuidadores.

Estudos sobre a percepção do paciente foram encontrados na literatura em menor escala. Após o término da terapia antineoplásica, Hockenberry-Eaton, Dilorio e Kemp (1995) 
avaliaram 44 crianças, entre seis e 13 anos, comparando a influência do tempo de experiência do câncer e a ocorrência da recidiva para a autopercepção (Harter Self Perception Profile), estressores (About my ilness Inventory), ansiedade-traço (Spielberg Stte Trait Anxiety Scale) e uso de estratégias de enfrentamento (Children's Coping Strategies Inventory). Os autores destacaram a percepção das crianças em idade escolar sobre as questões que envolviam o prognóstico da recidiva, considerando as reações apresentadas diante da incerteza. Além disso, identificaram relação entre o tempo de vivência oncológica e a presença de recidiva com maiores níveis de traço de ansiedade e menor autoestima. Dessa forma, incentivaram o desenvolvimento de estratégias apropriadas para a escuta e o suporte da criança, a fim de favorecer o senso de valia e atenuar a ansiedade, com maior atenção a essas dimensões ao longo do tratamento, a fim de ampliar a qualidade de vida dos pacientes.

Preocupados com as diferenças no ajustamento infantil, em diferentes momentos do tratamento oncológico, Grootenhuis e Last (2001) buscaram identificar variáveis preditoras do ajustamento psicológico nessas crianças. Estudaram 84 crianças com câncer, por meio da resposta a questionários para avaliação de estratégias de controle (CognitiTe Control Strategy Scale for Children), defesas (Defense Scale for Children), ansiedade (Trait Anxiety Inventory) e depressão (Depression Questionnaire for Children). Os resultados não indicaram diferença significativa quanto à ocorrência ou não da recidiva. De forma geral, as crianças com recidiva tumoral se mostraram capazes de preservar expectativas positivas sobre o curso da doença e confiança na equipe. $\mathrm{O}$ ajustamento emocional pareceu mais relacionado à capacidade de defesa e às expectativas positivas sobre a evolução da doença, do que à perspectiva de sobrevivência em si.

Em adolescentes, Essig et al. (2012) comparam a avaliação da qualidade de vida em sobreviventes de Leucemia Linfoide Aguda com a população geral e, ainda, avaliaram as diferenças entre a qualidade de vida, segundo a ocorrência ou não da recidiva. Os materiais de coleta de dados foram enviados para todos os sobreviventes há mais de cinco anos, registrados no registro Suíço de Câncer Infantil (Swiss Childhood Cancer Registry), alcançando um total de 457 participantes. A avaliação da qualidade de vida foi implementada por meio do Short Form 36 que evidenciou que, em comparação com a população geral, os sobreviventes de LLA obtiveram índices iguais ou superiores em todas as escalas. Quanto aos sobreviventes com recidiva, obtiveram piores escores na percepção geral de saúde, com resultados significativos e independentes. Os autores destacaram a provável associação com a presença de efeitos tardios como, por exemplo: atrasos do crescimento, desenvolvimento e 
maturação sexual que ocorrem em $75 \%$ dos pacientes curados, fazendo-se necessário o acompanhamento médico regular ao longo da vida (Haddy \& Haddy, 2010).

Os estudos sobre a vivência do paciente, de forma semelhante ao exposto sobre a perspectiva dos pais, apontaram sobre a vivência da incerteza e ansiedade. A recidiva apareceu como favorecedora de sintomas de ansiedade e diminuição da autoestima sem, no entanto, trazer diferenças significativas à percepção da qualidade de vida em comparação aos sobreviventes sem a experiência da recaída neoplásica. Os autores sugeriram intervenções com o paciente no que se refere ao manejo de ansiedade, promoção de capacidade de defesa e de expectativas positivas em relação à evolução da doença, com vistas ao ajustamento emocional.

De uma forma geral, os estudos selecionados ofereceram um panorama sobre os temas investigados no âmbito da recidiva em Oncologia Pediátrica, no que tange às repercussões psicossociais à vivência do paciente e seus familiares. Em face ao baixo número de publicações selecionadas na revisão de literatura, constatou-se que ainda são poucas as investigações científicas que oferecem luz à temática. No entanto, a sistematização dos achados permitiu a reflexão sobre os sentimentos experimentados pelas crianças e seus familiares diante do diagnóstico e tratamento da recaída, pensando sobre seus estressores, implicações para a qualidade de vida e para o enfrentamento. Por fim, acredita-se que, compreender as experiências, dificuldades e desafios pode auxiliar na organização da atenção integral diante desse momento do tratamento. 


\section{MARCO TEÓRICO-CONCEITUAL}

A palavra Fenomenologia vem da união de duas palavras gregas, phainomai e logos, tendo como definição a descrição do fenômeno, enquanto aquilo que surge ou se mostra. Para Husserl, a Fenomenologia se caracteriza como ciência e tem como foco o fenômeno, tal como se revela para a consciência. Assim, emergiu a Fenomenologia Transcendental, como uma doutrina em busca da essência do conhecimento a priori, sem valer-se do empirismo e das disciplinas até então destacadas nessa função, como a matemática, a geometria ou a lógica. $\mathrm{O}$ interesse estaria direcionado à consciência, compreendida como intencional e direcionada a algum objeto, sem o uso de mediadores empíricos nesse sentido, a fim de acessar a essência da vida humana e sua subjetividade (Goto, 2008).

Com o propósito de voltar-se às coisas mesmas, o filósofo propôs o método fenomenológico, no qual se estuda a relação entre a experiência e a consciência, com o objetivo de clarificar a experiência para a consciência, enquanto abertura para o mundo e compreensão em sua complexidade, que envolveria desde a história de vida, perpassando pelas crenças e projetos de vida (Forghieri, 1993). Nesse sentido, propôs o contato direto e espontâneo com a experiência, não enquanto objeto externo ou interno ao conhecimento, mas como base das coisas objetivas e subjetivas. Goto (2008) descreveu o método fenomenológico pautado em três elementos: epoché, redução eidética e redução fenomenológica ou transcendental.

Epoché representaria uma postura crítica de suspender todo o conhecimento e a subjetividade, a fim de permitir o contato direto com a vivência, de forma espontânea e livre. Dessa forma, seria possível a passagem de uma postura natural, com crenças e valores, para a atitude fenomenológica, marcada pela imparcialidade na reflexão da vida cotidiana, que permite ultrapassar a pura descrição psicofísica dos fenômenos rumo ao acesso da consciência transcendental (Forghieri, 1993; Goto, 2008).

A redução teria por objetivo favorecer a abertura para o novo presente nas experiências singulares, de forma a estabelecer uma relação entre o mundo e a consciência (Gomes \& Castro, 2010), sendo compreendida como uma recondução à subjetividade absoluta e à essência das coisas. A primeira foi denominada redução transcendental, responsável pela passagem do ego empírico para o ego transcendental, a partir da postura fenomenológica diante das coisas. Já a redução eidética favoreceria a explicitação dos 
sentidos dos fenômenos para a consciência, preocupada com o acesso a sua essência (Goto, 2008).

Buscando articulações com o fazer científico, Forghieri (1993) defendeu a relevância do equilíbrio entre o envolvimento existencial e o distanciamento reflexivo, a fim de compreender a vivência em sua totalidade. Na primeira posição, o pesquisador deveria buscar se despir do conhecimento acumulado e intelectualizado, permitindo a emergência da intuição e de uma atitude pré-reflexiva da experiência do encontro com o sujeito. Em um segundo momento, propôs a tentativa de refletir sobre a vivência, com foco em sua descrição e revelação dos sentidos daquele existir. Cabe ressaltar que o distanciamento em questão não prevê a ruptura do vínculo com a experiência, importante para a constituição do encontro intersubjetivo, mas uma facilitação da reflexão sobre o que se revelou (Forghieri, 1993).

Da mesma forma, Husserl buscou aproximações entre a Fenomenologia e a Psicologia. Para Husserl, a Fenomenologia foi definida como um método filosófico descritivo, capaz de fundamentar a Psicologia pura e a revisão de todas as ciências, por se caracterizar como uma filosofia universal (Gomes \& Castro, 2010). Trata-se de uma posição racional da Psicologia que se propôs a articular a busca de significação e estudos normativos e científicos (Augras, 1986; Gomes \& Castro, 2010; Goto, 2008). Segundo Goto (2008), o fenomenólogo defendia que, com as contribuições da Fenomenologia, a Psicologia poderia descrever as estruturas psíquicas no âmbito da subjetividade transcendental. Assim, a Psicologia Fenomenológica teria como foco a vida interna e subjetiva do homem, enquanto vivência intencional, fazendo uso dos princípios básicos descritos anteriormente.

No Brasil, os primeiros contatos com a Fenomenologia datam da década de 1930, majoritariamente enquanto inspiração o contexto científico, porém também como possibilidade de articulação com a Psicologia. A partir de 1960, notou-se importante crescimento da Psicologia Fenomenológica, com a prática realizada por psicólogos humanistas, notadamente da Abordagem Centrada na Pessoa, difundida por Carl Rogers, tendo seu desenvolvimento um foco clínico, mais do que na preocupação com o método husserliano em si (Gomes \& Castro, 2010; Goto, 2008). Apesar da crescente atenção à Fenomenologia como abordagem psicológica, marcada por cursos e especializações na área, o autor pontuou sobre a questão da pluralidade de formas que vêm sendo desenvolvidas, muitas vezes sem a devida diferenciação da Filosofia Fenomenológica, proposta por Husserl, e de suas relações com a Psicologia, o que acarretaria perdas para a construção do campo de estudo e definição das estratégias de atuação (Goto, 2008). 
O estudo das relações estabelecidas entre homem e o mundo se mostraram importantes para a compreensão da essência humana, enquanto estrutura complexa e unitária (Forghieri, 1993). A autora, em seus estudos sobre o enfoque fenomenológico da personalidade, definiu o mundo a partir das relações estabelecidas pelo homem em sua existência, compreendida como a integração das dimensões no âmbito circundante, humano e próprio.

O "mundo circundante" seria composto por todas as relações com o ambiente externo e o próprio corpo, sendo este responsável pelo contato com os objetos e favorecedor do processo de suas significações (Forghieri, 1993). O sentido dos objetos não se daria a priori, mas apenas na relação entre a experiência e a consciência (Forghieri, 1993; Gomes \& Castro, 2010). Nesse sentido, a compreensão do mundo se daria enquanto manifestação mediada pela percepção do homem, favorecendo a consciência do mundo e também de si mesmo (Augras, 1986). Ao discutir a necessidade de adaptação do homem ao mundo circundante, Forghieri (1993) aborda as tentativas em exercer controle sobre suas condições, porém sempre temporárias e situacionais, sendo a morte uma das maiores concretizações desta impossibilidade.

O "mundo humano" seria o espaço compartilhado com o outro, envolvendo as vivências e as possibilidades próprias das relações humanas. O contato com o outro ofereceria condição para a percepção de si mesmo como humano, na lida com as semelhanças, as peculiaridades e os atos intencionais (Forghieri, 1993; Gomes \& Castro, 2010).

Dessa forma, o "mundo próprio" se caracterizaria como a relação do homem consigo mesmo e seu processo de autoconhecimento, em contato com seus sentimentos, recursos e possibilidades (Forghieri, 1993). No contexto do psicodiagnóstico, Augras (1986) destacou a importância da descrição do mundo próprio do cliente desvinculada de interpretações ou procedimentos a priori do acontecer do encontro, a fim de permitir a apreensão global de sua situação no momento da avaliação.

Ainda no que tange à compreensão da existência, mostra-se relevante somar a aproximação das três dimensões do mundo à atenção da relação estabelecida pelo homem com a temporalidade, espacialidade e com a questão da escolha e realização (Augras, 1986; Forghieri, 1993).

A temporalidade pode ser compreendida como a capacidade do homem em transitar entre o passado e o futuro, ultrapassando a realidade imediata, de forma a se responsabilizar por suas escolhas e a se abrir para as possibilidades da existência (Forghieri, 1993). Para Augras (1986), o tempo é compreendido enquanto parte do ser e responsável por sua orientação significativa diante dos conflitos essenciais. Assim, ao projetar-se para o futuro e 
para a impossibilidade de controle sobre o decorrer do tempo, o homem se depara com obstáculos e com a certeza da morte. Diante disso, a liberdade trazida pelas possibilidades vislumbradas se contrapõe à consciência do ser para a morte, colocando a transcendência enquanto possibilidade de realização do indivíduo (Augras, 1986; Forghieri, 1993).

O espaço é definido como a corporeidade, não limitado à carne, mas abrangendo suas extensões no âmbito existencial, sendo a elasticidade dessas extensões correlacionada à forma individual de ser no mundo. Observar a liberdade do indivíduo nesse contexto pode trazer informações sobre sua capacidade de estabelecer limites e, ao mesmo tempo, criação de novas possibilidades e adaptação (Augras, 1986; Forghieri, 1993). Forghieri (1993) pontuou que as experiências da espacialidade e temporalidade caminham próximas, de forma a permitir a vivência da proximidade e do distanciamento independentemente da presença concreta do fato, pessoa ou objeto.

Já a questão da escolha remete para a abertura às possibilidades da existência. Ao mesmo tempo em que possibilita a liberdade, implica em assumir uma postura de responsabilidade diante dos riscos e da imprevisibilidade do futuro, além de significar a interrupção de diversas possibilidades do vir a ser. Assim, conforme as decisões e atitudes, o homem estabelece novos contatos com o mundo e constrói seu caminho, em constante transformação, rumo à compreensão do mundo e de si mesmo (Forghieri, 1993).

Forghieri (1993) defendeu que a integração das dimensões do ser no mundo, da temporalidade, da espacialidade e da escolha traria indícios sobre o processo saúde-doença existencial. Notadamente, a capacidade de reconhecer as limitações, enfrentar os conflitos e significar o sofrimento permitiria a emergência da transcendência e de vislumbrar a amplitude de suas possibilidades. Nesse sentido, a Fenomenologia será utilizada neste estudo não como referencial metodológico, mas como um olhar possível de ser lançado às vivências singulares dos participantes e à apreensão global das implicações da recidiva oncológica na saúde existencial. 


\section{DELIMITAÇÃO DO PROBLEMA DE INVESTIGAÇÃO}

Considerando as implicações psicossociais suscitadas pelo câncer e seu tratamento, foi publicada, em 1998, a Portaria $\mathrm{n}^{\mathrm{o}} 3.535$ do Ministério da Saúde que tornou obrigatória a presença do psicólogo em serviços de atenção à oncologia cadastrados para atendimento pelo Sistema Único de Saúde (Ministério da Saúde, 1998). Tal decisão fortaleceu a crença na necessidade de um modelo biopsicossocial de atenção à saúde, rompendo a dicotomia mentecorpo instaurada pelo modelo biomédico. Nesse novo paradigma, o foco da atenção passa da doença para a pessoa doente, e foram propostos a atenção integral e o compartilhamento das responsabilidades no tratamento entre paciente e equipe multidisciplinar (Perina, 2005). O psicólogo, nesse contexto, atua com dupla função no atual período de transição entre os modelos de atenção: assistir o paciente e os seus familiares e, também, clarificar e delimitar a função da Psicologia no contexto da saúde (Romano, 2007).

Define-se como Psico-Oncologia a área de interface entre a Psicologia e a Oncologia, que assume, como objeto de estudo, as questões psicossociais do processo de adoecimento (Carvalho, 2002). Internacionalmente, o campo de estudo se caracteriza como uma especialidade da Oncologia, com o objetivo de estudar aspectos psicológicos envolvidos no diagnóstico e prognóstico da doença. No Brasil, surgiu vinculada à prática da Psicologia da Saúde, com ênfase na atuação interdisciplinar, porém ainda se identifica um predomínio de psicólogos em sua prática (Costa Junior, 2001). Notou-se grande expansão da área nas últimas décadas, com aumento do número de investigações científicas, possivelmente associadas à percepção do papel de aspectos psicológicos enquanto fatores de risco para o desenvolvimento da doença, os aspectos de psiconeuroimunologia e a relevância do cuidado humanizado aos pacientes (Burón et al., 2008; Campos, 2010).

No contexto de intervenção, configuram-se ações preventivas, como a educação da população sobre fatores de risco e proteção, a instrumentalização para a detecção precoce das doenças e a capacitação de professores e de profisssionais de saúde, além de intervenção terapêutica no processo de tratamento, preocupando-se com o impacto do adoecer nas vivências emocionais e psíquicas do paciente, de seus cuidadores e da equipe, buscando favorecer o enfrentamento, a adesão à terapêutica e a promoção de qualidade de vida, tanto na temporalidade da cura, como no período final de vida (Oliveira, Santos, \& Mastropietro, 2010; Perina, 2005). 
Segundo Staliano e Araújo (2009), as pesquisas em Psico-Oncologia nas duas últimas décadas tiveram como principais temas: aspectos psicossociais do paciente, como enfrentamento, estresse, fatores emocionais e qualidade de vida; seguidos de análises das intervenções implementadas e do impacto do adoecimento no âmbito familiar, o que sugeriu a valorização da compreensão das vivências do paciente e dos familiares e da adequação das ações terapêuticas voltadas a essa população. No entanto, as autoras destacaram que os estudos brasileiros ainda são parcos e pouco representativos da incidência e epidemiologia do câncer no país, sendo referidos maiores esforços no desenvolvimento teórico e prático.

No Brasil, os estudos sobre a perspectiva psicossocial do câncer infantil abordam, principalmente, o impacto do diagnóstico e do período de tratamento - ou no que se refere aos modos de enfrentamento (Beltrão et al., 2007; Castro, 2010; Hildenbrand et al., 2011; Lemos, Lima, \& Mello, 2004; Motta et al., 2006; Paiva, 2007; Paulo et al., 2008) ou às possibilidades de atenção psicológica nesse momento (Costa Junior, 1999; Françoso, 2001; Kohlsdorf \& Costa Junior, 2011; Perina, 1992), ou à perspectiva da família (Espíndula, 2001a, 2001b; Gibbins et al., 2012; Long \& Marsland, 2011; Malta, Schall, Reis, \& Modena, 2008; Paulo et al., 2008) e às vivências na temporalidade de cura, incluindo o receio da recidiva e da adaptação psicossocial (Arrais \& Araujo, 1999; McKenzie \& Curle, 2012; Teles \& Valle, 2009). Apesar de haver um número crescente de artigos sobre o impacto do tratamento no desenvolvimento infantil (Kohlsdorf, 2010), poucos estudos se detêm na percepção do paciente frente à situação de adoecimento (Almeida, 2005; Malta et al., 2008; Melo, 2001; Menossi \& Lima, 2000).

A literatura internacional destaca a presença de elevados níveis de ansiedade associados ao tratamento do câncer infantil e ao diagnóstico de recidiva (Espíndula, 2001a, 2001b; Hockenberry-Eaton et al., 1995; Vivar et al., 2009). No entanto, constata-se uma lacuna de investigações acerca das vivências das crianças nessa fase do tratamento (Silva, Teles, \& Valle, 2005; Vivar et al., 2009). Nesse sentido, no presente estudo buscou-se oferecer um espaço de escuta e de expressão para a criança, enquanto estratégia de acesso a aspectos de sua experiência emocional diante do tratamento da recidiva oncológica, assim como de promoção de sentimentos de respeito, autonomia e segurança, com vistas ao favorecimento do enfrentamento da situação de adoecimento e ao desenvolvimento de sua maturidade (Castelo, 2003; Kóvacs, 1992). Considerando, ainda, as ressonâncias da compreensão e do impacto na dinâmica familiar para a lida infantil, optou-se pela escuta do cuidador-familiar, a fim de ampliar a compreensão sobre o momento do tratamento e aprimorar a atenção psicológica à unidade de cuidado paciente-família. 


\subsection{Objetivo geral}

O presente estudo teve como objetivo compreender as vivências de crianças, em tratamento de recidiva de câncer infantil, bem como de seus cuidadores principais.

\subsection{Objetivos específicos}

a. Conhecer o histórico de adoecimento e o itinerário terapêutico da criança;

b. Desvelar a vivência familiar acerca da recidiva oncológica infantil, na perspectiva do cuidador-familiar;

c. Compreender os significados atribuídos à recidiva oncológica e fantasias a ela associadas, em crianças que experimentam tal fase de tratamento;

d. Identificar possíveis relações estabelecidas entre a compreensão familiar acerca da recidiva e a compreensão da criança. 


\section{MÉTODO}

\subsection{Contextualização metodológica}

O presente estudo se caracteriza como um estudo qualitativo, conceituado como a escolha de teorias, técnicas e instrumentais para a abordagem da realidade com o objetivo de acessar o sentido e a intencionalidade intrínsecos aos fenômenos humanos e às relações interpessoais, considerando significados atribuídos pelos indivíduos e pela sociedade (Minayo, 2008; Turato, 2003). Segundo Crossley (2007), tal escolha metodológica se fez presente no âmbito da saúde a partir do reconhecimento da amplitude de possibilidades de investigações no que tange aos problemas de saúde e aos processos de cuidar, para além do olhar quantitativo, notadamente quando se objetivavam compreender os significados e as percepções dos envolvidos no cuidado em saúde. No âmbito da doença grave e de cuidados paliativos, o uso da pesquisa qualitativa mostrou-se pertinente, por permitir o foco em objetivos específicos, o desenvolvimento com recursos restritos de tempo e dinheiro e, principalmente, com exigência de pouca tolerância a procedimentos de pesquisa por parte dos participantes, muitas vezes fragilizados (Payne, 2007).

A investigação qualitativa tem como principais características a flexibilidade do desenho da pesquisa, adequado aos objetivos propostos e às demandas identificadas para acessá-lo; uma postura ativa do pesquisador na criação dos dados e na análise e sua atitude de compreensão, com o objetivo de apreender o nexo de sentido de determinado fenômeno (Turato, 2003). Dessa forma, os temas focalizam ocorrências específicas, a fim de oferecer um aprofundamento na reflexão e compreensão daquilo que se mostra, enquanto singularidade, oferecendo menor valor à comparação, à generalização e ao tamanho da amostra, muitas vezes definido apenas após a coleta e análise dos dados concomitantes, com a identificação do ponto em que se considera suficiente a produção de conhecimento para a compreensão do fenômeno (Crossley, 2007; Turato, 2003). A força da investigação se encontra na validade, tanto interna, representada pelo preparo do pesquisador e pelo planejamento adequado da pesquisa, quanto externa, apresentada pelas supervisões no delineamento e no desenvolvimento científico, na discussão com pares em grupos de pesquisa e em reuniões científicas, além do referendo oferecido pela publicação dos achados (Turato, 2003). 
O presente estudo se caracterizou como uma investigação clínico-qualitativa (Turato, 2003), conceituada enquanto estratégia científica de acesso aos sentidos e significações atribuídos, por parte da população investigada, aos fenômenos associados ao processo saúdedoença. Nesse sentido, a Fenomenologia foi utilizada enquanto embasamento téorico para o olhar às vivências dos participantes, diante do objeto de investigação proposto.

Optou-se pela realização de estudos de casos que, apesar de não serem restritos ao campo de estudo de pesquisas qualitativas, se apresentam enquanto estratégia para o aprofundamento em questões contextuais complexas, a partir da coleta de informações no âmbito geral sobre poucos "casos", caracterizados como sistemas unitários e multidimensionais, atento às semelhanças e às singularidades das experiências, com vistas à compreensão global do fenômeno (Ingleton \& Davies, 2007; Stake, 2000). Segundo Bodgan e Biklen (1997), trata-se de uma observação minuciosa de um determinado contexto, indivíduo ou documento, podendo ter diferentes graus de complexidade.

Dentre as modalidades de estudo de caso, encontram-se os estudos de casos múltiplos, nos quais são eleitos para análise mais de um tema ou ambiente (Bodgan \& Biklen, 1997). Tal proposta se mostrou pertinente ao objetivo desta investigação, por envolver a integração de experiências específicas e globais do contexto, consideradas como unidade de análise, a fim de acessar a complexidade envolvida no fenômeno (Ingleton \& Davies, 2007; Peres \& Santos, 2005; Triviños, 1992). Cabe ressaltar que, considerando a validade científica das estratégias em questão, torna-se importante a atenção à escolha dos casos a serem estudados, à definição clara dos objetivos da investigação, à postura do pesquisador na descrição e análise dos dados, além da articulação com a base téorica (Peres \& Santos, 2005).

\subsection{Local do estudo}

O Centro Infantil de Investigações Hematológicas Dr. Domingos Ademar Boldrini se caracteriza como um hospital de referência internacional no tratamento de crianças e adolescentes com câncer e com doenças hematológicas. Situado na cidade de Campinas/SP, atende pacientes advindos de diferentes localidades do país e do exterior (Centro Infantil Boldrini, 2010). No ano de 2011, totalizaram 781 casos novos, sendo 285 destes específicos da Oncologia, com 74\% dos atendimentos realizados pelo Sistema Único de Saúde.

O hospital conta com equipe multiprofissional especializada (médicos, enfermeiros, assistentes sociais, dentistas, nutricionistas, psicólogas, fisioterapeutas, farmacêuticos, pedagogas, terapeuta ocupacional, fonoaudióloga, brinquedistas, capelania e voluntariado, 
previamente treinados para a atuação em Oncologia Pediátrica) e oferece atendimento integral e humanizado aos pacientes e a seus familiares. Conta, ainda, com o Instituto de Pesquisa Boldrini (IPEB) que funciona como centro multiplicador de conhecimentos, através do desenvolvimento científico, da formação de profissionais de saúde (Residência Médica e Programa de Aprimoramento Profissional não médico) e dos eventos de educação permanente oferecidos para a comunidade (Centro Infantil Boldrini, 2010).

\subsection{Participantes}

Foram considerados como participantes potenciais deste estudo crianças com câncer, em situações de recidiva da doença e seus cuidadores principais ${ }^{1}$. Considerando o desenvolvimento gráfico e verbal infantil (Correia, Oliveira, \& Vieira, 2003) e a definição de “criança" no Estatuto da Criança e do Adolescente (Lei 8.069/90, 1990), delimitou-se a faixa etária entre cinco e 12 anos incompletos. Essa amplitude de faixa etária foi definida com base na literatura e também levando em conta o conhecimento da realidade assistencial do serviço, uma vez que um maior estreitamento da faixa etária poderia restringir em excesso o número de participantes potenciais.

Foram definidos como critérios de exclusão da criança: (1) dificuldades motoras, de compreensão e/ou da comunicação, que inviabilizassem o uso do instrumento definido para coleta de dados e; (2) pacientes fora de possibilidades terapêuticas curativas. No que se refere ao cuidador-familiar, foram critérios de inclusão: (1) ser mãe, pai ou responsável legal da criança e se apresentar, perante o serviço, como cuidador principal da criança e; (2) estar de acordo com a participação própria e do(a) filho(a) na pesquisa. Como critérios de exclusão para cuidadores, definiu-se a presença de dificuldades de compreensão e/ou de comunicação que inviabilizassem a aplicação da entrevista.

Considerando os aspectos da escolha metodológica e das características da temática em questão, optou-se pela definição amostral por saturação teórica, na qual a coleta de dados foi interrompida após a avaliação de que os elementos obtidos seriam satisfatórios para a discussão, sendo que novos dados não significariam um aprofundamento na compreensão do fenômeno estudado (Fontanella et al., 2011; Turato, 2003).

\footnotetext{
${ }^{1}$ Para fins deste estudo, considerar-se-á cuidador principal o adulto (pai, mãe ou responsável legal) que se apresenta nessa condição à instituição hospitalar. Nos casos em que houve mais de um adulto reconhecido pela equipe de saúde como cuidador, foi solicitado que eles próprios designassem aquele que desejaria participar do estudo.
} 


\subsection{Instrumentos}

A fim de atender aos objetivos do estudo, foram utilizados como instrumentos uma entrevista de anamnese com o acompanhante responsável (Apêndice A) e o procedimento de Desenhos-Estórias com a criança.

\subsubsection{Entrevista}

A entrevista representa uma das estratégias para a investigação de concepções, crenças, valores e atitudes dos participantes, ao oferecer um espaço de expressão e espontaneidade na relação entrevistador-entrevistado (Minayo, 2008). Ao discorrer sobre as estratégias de coleta de dados, Payne (2007) clarificou os diferentes tipos de entrevista e pontuou sobre a adequação de seu uso no contexto de atenção a pacientes graves, por ser construída na relação pesquisador-paciente e ter caráter benéfico implícito ao ato da escuta. A entrevista semiestruturada, como é o caso do instrumento utilizado neste estudo, se caracteriza pela definição prévia de tópicos a serem abordados, porém com flexibilidade para sua aplicação, exclusão e inclusão de novos tópicos, conforme o encaminhar do encontro (Minayo, 2008; Payne, 2007). Dessa forma, o roteiro de entrevista foi delineado pelos pesquisadores, com base na literatura disponível e nos temas de interesse à temática investigada. Abordou questões sobre a dinâmica familiar, desenvolvimento infantil e histórico de adoecimento e tratamento, a fim de ampliar os conhecimentos acerca das experiências da criança e da família ao longo do tratamento e acessar as repercussões emocionais do diagnóstico de recidiva na dinâmica familiar.

\subsubsection{Procedimento de Desenhos-Estórias}

O procedimento de Desenhos-Estórias (D-E) foi desenvolvido como método de investigação clínica da personalidade, a fim de favorecer uma ampliação do conhecimento de dinamismos psíquicos pouco acessíveis verbalmente (Trinca, 1997). O autor posiciona o procedimento como favorecedor do diagnóstico compreensivo, oferecendo um espaço de acolhimento às expressões de conflitos experienciados, ao passo que permite ao profissional o acesso aos sentidos singulares da existência individual (Trinca, 1997).

$\mathrm{O}$ instrumento tem sido utilizado no contexto brasileiro para a avaliação psicológica de crianças e adolescentes, sem restrições de uso quanto ao sexo, ao nível cognitivo e ao 
contexto sociocultural. Enquadra-se dentre as técnicas gráficas e de apercepção temática, por utilizar o desenho como forma de projeção de aspectos inconscientes de sua personalidade e associar a expressão verbal de sua interpretação da percepção (Bomfim \& Barbieri, 2009). A partir do oferecimento de estímulos pouco estruturados e de condições de implementar associações livres, espera-se obter um material subjetivo significativo, com a revelação de conflitos e disposições inconscientes da personalidade (Trinca, 1997).

A aplicação em crianças se justifica por unir o desenho e o contar de histórias, modos preferenciais de comunicação nesta faixa etária, sendo escolhido por propor uma situação lúdica sem apontar diretamente para a situação de doença ou tratamento pela qual a criança está passando, porém capaz de favorecer sua expressão simbólica. Desse modo, na escolha dessa técnica está implícita a facilitação de um contexto protegido e sensível ao momento de vida da criança, respeitando suas defesas e priorizando suas necessidades. Perina (1992) utilizou o instrumento com crianças em fase terminal de câncer, enquanto auxiliar ao contato e à compreensão dos processos psicológicos. Mostrou-se um facilitador na obtenção de informações e nas intervenções terapêuticas, ratificando a pertinência da escolha metodológica para a população deste estudo e também aos objetivos propostos.

Augras (1986) defendeu que, ao ser convidado a criar histórias, o homem transita em sua multiplicidade, sendo a Fenomenologia ferramenta útil na compreensão das contradições e do processo de construção da personalidade. Na perspectiva fenomenológica, o uso de instrumentos de avaliação é compreendido como estratégia de interação, de forma a favorecer um maior acesso às questões da vida cotidiana e às formas de lida com determinadas situações (Ancona-Lopez, 1997; Augras, 1986). Considerando o princípio da intencionalidade, para a adequada aproximação e direcionamento para o conhecimento da vida psíquica da pessoa, torna-se imperativa a consideração dos aspectos de seu contexto de vida, enquanto ser em relação consigo, com o outro e com o mundo (Cupertino, 1995). Além disso, implica no foco à experiência vivida e aos sentidos atribuídos pelo sujeito, sendo primordial para este fim o estabelecimento de uma relação de confiança mútua, para possibilitar o diálogo e o encontro, como ação integrativa rumo à compreensão de si mesmo. Dessa forma, a reflexão, a ação e a comunicação, ao longo do proceso de investigação, tornam-se fundamentais para a apreensão da experiência existencial (Munhóz, 1995).

O olhar fenomenológico ao material implica na articulação com a história de vida do participante e da análise com foco naquilo que se mostra claramente em sua expressão. Assim, os dados obtidos por meio da aplicação de instrumentos são utilizados como complementares às informações sobre a vida infantil e às questões relevantes da vivência, de 
forma a contribuir com a apreensão compartilhada e global da experiência individual e familiar (Ancona-Lopez, 1997).

\subsection{Procedimento}

\subsubsection{Coleta de dados}

Os contatos iniciais com os participantes foram realizados por intermédio das psicólogas do setor de Saúde Mental da instituição onde ocorreu a coleta de dados. Primeiramente, foram contactados os cuidadores-familiares, em retorno ambulatorial ou durante a internação, oportunidade na qual foram apresentados a investigação científica, os objetivos e as etapas da coleta de dados. Em seguida, foi realizado o convite para participação, pontuando a participação voluntária. Quando autorizado, foi realizado o contato com a criança, também com o suporte da psicóloga de referência e/ou cuidador-familiar, sendo apresentada a pesquisa e feito o convite para a participação.

A coleta de dados foi realizada em local apropriado, na instituição hospitalar, de forma a respeitar os preceitos éticos e oferecer condições de conforto e privacidade para favorecer a expressão dos participantes. Foi feita em dois momentos, sendo o primeiro destinado à entrevista com a família (Apêndice A) e o segundo, à aplicação do procedimento de Desenhos-Estórias com a criança, conforme orientações da literatura (Trinca, 1997).

A entrevista exigiu a disponibilidade de um gravador de áudio e de folhas para anotação de pontos importantes das entrevistas. A aplicação do procedimento de DesenhosEstórias requer folhas de papel em branco, conjunto de 12 lápis de cor, lápis preto, gravador de áudio. Consiste em solicitar que a criança faça cinco desenhos livres, com a seguinte instrução: "Você tem essa folha em branco e pode fazer o desenho que quiser, como quiser". Ao final de cada produção, a criança é solicitada a contar uma estória sobre o desenho (“Agora, olhando o desenho, você pode inventar uma estória, dizendo o que acontece”). Concluída essa etapa, realiza-se um inquérito com o objetivo de esclarecer pontos obscuros no desenho e/ou na história. No encerramento, pede-se que seja dado um título a cada unidade de produção, constituída pelo conjunto formado pela produção gráfica e respectiva estória (Trinca, 1997).

Trinca (1997) propôs a produção de cinco unidades de Desenhos-Estórias, em duas sessões de uma hora, enquanto comunicação contínua acerca dos pontos focais de angústia. 
No entanto, o autor ressaltou a importância da atenção ao participante em caso de dificuldade na conclusão da produção, considerando aspectos clínicos e emocionais, sendo interrompida a aplicação e considerado o conteúdo obtido nas unidades de Desenhos-Estórias realizadas até o momento (Trinca, 1997). Assim, durante toda a coleta de dados, a pesquisadora, que possui experiência clínica no atendimento a crianças com câncer, esteve atenta às necessidades e limitações de cada criança e cuidador-familiar, priorizando a manutenção da integridade física e psíquica dos participantes.

As sessões de entrevista com o cuidador e de aplicação do procedimento de DesenhosEstórias com a criança foram audiogravadas, quando autorizado pelos familiares, e transcritas na íntegra, a fim de permitir a constatação da saturação teórica dos dados e subsidiar a análise do material. No caso da negativa à gravação, o relato foi registrado na íntegra, ao longo da entrevista.

\subsubsection{Análise dos dados}

Os dados foram analisados por meio da análise de conteúdo temática, com vistas aos temas inerentes às expressões verbais e gráficas dos participantes (Turato, 2003). Em um primeiro momento, foi realizada uma leitura integral das entrevistas e dos conjuntos de narrativas dos Desenhos-Estórias, a fim de se obter uma compreensão geral do conteúdo a ser analisado, atendo-se às impressões, às contradições e aos conteúdos explícitos e implícitos. Em seguida, foi implementada a busca de núcleos temáticos, com atenção aos temas relevantes ao olhar do pesquisador ou da literatura específica, independentemente de sua recorrência, em defesa da riqueza acrescida à discussão em termos do acesso à essência do fenômeno sob estudo (Turato, 2003). A análise do conjunto de Desenhos-Estórias obedeceu às recomendações de Trinca (1997) e Ancona-Lopez (1997), sendo considerados os movimentos gráficos e verbais, a fim de oferecer um panorama geral sobre os conflitos vivenciados, bem como possibilitar o acesso à dinâmica de recursos que a criança utiliza para lidar com situações de conflitos básicos, obtendo-se informações sobre sua capacidade adaptativa diante das situações experimentadas (Safra, 1984).

$\mathrm{Na}$ terceira etapa, os dados das crianças e dos familiares foram aproximados, a fim de se alcançar o último objetivo específico. Cabe ressaltar que, para fins da investigação, foram realizados estudos de casos múltiplos (Peres \& Santos, 2005; Triviños, 1992) que pressupõem a análise de diferentes objetos, neste estudo representados pelas crianças e seus cuidadores. 
Nesse sentido, foram enfatizadas as experiências singulares dos participantes e também das díades criança-cuidador, enquanto um sistema unitário e multifacetado (Stake, 2000).

Por fim, buscou-se aproximar as vivências dos cuidadores, das crianças e das díades diante da experiência da recaída da doença, em nível horizontal, com vistas à compreensão global do fenômeno estudado e possibilidades de articulação téorica. A etapa final do processo de análise correspondeu à tentativa de integração teórica acerca dos resultados do estudo, para uma aproximação em relação aos aspectos essenciais para a apreensão clínica do fenômeno em questão (Turato, 2003). 


\section{CUIDADOS ÉTICOS}

Além dos cuidados já mencionados nos itens Instrumentos e Procedimento, é importante ressaltar que o projeto de investigação contou com a anuência da instituição hospitalar na qual foram coletados os dados. De fato, o projeto foi submetido à avaliação e aprovado pelo Comitê de Ética em Pesquisa do Instituto de Pesquisa do Boldrini (Anexo A), junto com o Termo de Consentimento Livre Esclarecido (Apêndice B), elaborado conforme resoluções do Conselho Nacional de Saúde (1996) e do Conselho Federal de Psicologia (2000).

No contato com os participantes, foi reforçado o caráter voluntário da participação na pesquisa, com informações sobre os objetivos e procedimentos do estudo. Os cuidadores formalizam sua participação por meio da assinatura do Termo de Consentimento Livre Esclarecido, no qual, na condição de responsáveis legais pela criança, declararam ter ciência da liberdade para participação ou não do estudo, da possibilidade de desistência e retirada do consentimento em qualquer etapa da pesquisa, sem quaisquer prejuízos ao tratamento da criança, e do cuidado com a preservação da identidade dos participantes, no caso de divulgação científica. Além disso, foram atribuídos nomes fictícios aos pacientes e familiares, a fim de preservar sua identidade.

Considerando que a pesquisa é dirigida a pacientes que se encontravam em delicado estágio do tratamento oncológico, isto é, em tratamento da recorrência do câncer infantil, a pesquisadora se colocou à disposição para oferecer continência e assistência psicológica aos participantes que dela necessitarem, caso fossem mobilizados angústias e conflitos em decorrência da participação neste estudo. Cabe destacar que todos os participantes encontravam-se em acompanhamento psicológico sistemático pelo Setor de Saúde Mental da instituição hospitalar, tendo sido possível sessões de devolutiva com as psicólogas responsáveis pelos atendimentos. Os momentos de reflexão ocorreram em espaço reservado da instituição hospitalar, buscando aproximar os dados obtidos na avaliação realizada e os aspectos do seguimento psicológico regular estabelecido, pensando possibilidades de contribuições deste estudo para o cuidado emocional das crianças e familiares participantes, assim como de outros pacientes nessa fase de tratamento. A coleta de dados contou com o aval e apoio, in loco, da supervisora institucional, Profa. Dra. Elisa Maria Perina, psicóloga com ampla experiência no contexto da Oncologia Pediátrica. 


\section{RESULTADOS E DISCUSSÃO}

No percurso de coleta de dados, foi realizado um levantamento, junto aos profissionais da instituição, sobre as crianças, em tratamento de recidiva oncológica, que comporiam a amostra potencial. Após a confirmação da pertinência aos critérios de inclusão e exclusão para a participação do estudo, foram abordadas 13 famílias.

Houve duas recusas, sendo uma explícita, na qual a mãe justificou a não participação devido ao impacto emocional vivenciado diante do diagnóstico da recaída ainda bastante recente e indisponibilidade para entrar em contato com a temática naquele momento. Tal fato sensibilizou a pesquisadora para a atenção ao tempo transcorrido entre a comunicação diagnóstica e o convite para a participação em pesquisa, passando a aguardar um intervalo maior após a comunicação diagnóstica e/ou início de tratamento. A segunda família, apesar da assinatura do Termo de Consentimento Livre Esclarecido, desmarcou por duas situações a realização da entrevista e buscava se esquivar do contato com a pesquisadora. Compreendendo-se o conflito, no terceiro contato foi pontuado sobre a presença da pesquisadora na instituição e da possibilidade de busca espontânea em outro momento para participação, o que não foi verificado.

Foram realizadas 11 coletas de dados, sendo três não concluídas por situação de morte da criança, antes do cumprimento das etapas previstas. Tal experiência colocou a pesquisadora em contato com a dificuldade em trabalhar com a temática da recidiva, trazendo reflexões acerca da vulnerabilidade, da intensidade das vivências e sobre os aspectos éticos que favoreceram a sensibilização para especificidades da atenção em recidiva oncológica e das possibilidades de contribuição com o fazer científico neste contexto.

A caracterização da amostra final de participantes, composta pelas oito díades de crianças e seus cuidadores-familiares, foi ilustrada na Tabela 3. Inicialmente, foi realizada a apresentação da pré-análise dos oito conjuntos de dados, a fim de explicitar elementos da categorização temática das entrevistas com os cuidadores familiares e do D-E com as crianças. A partir desta pré-análise, foi identificada a saturação teórica a partir da quarta entrevista e do terceiro conjunto de Desenhos-Estórias, quando cessou o surgimento de novas categorias temáticas, conforme as Tabelas 4 e 5. Definiram-se, assim, as díades submetidas aos estudos de casos múltiplos, para maior aprofundamento nas vivências, apresentadas sinteticamente na Tabela 6. Foi realizada a análise das díades pacientes-cuidadores, propondo uma aproximação com o contexto familiar e com o processo saúde-doença infantil, seguidos 
pela apresentação das categorias temáticas da entrevista com o cuidador-familiar e do material produzido com a criança, além da síntese compreensiva de cada díade. Por fim, realizou-se uma aproximação das vivências compartilhadas diante da recidiva oncológica infantil, sob a perspectiva horizontal dos cuidadores, das crianças e das díades estudadas, propondo uma integração acerca das vivências e sua articulação com os dados da literatura.

Tabela 3.

Características sociodemográficas e clínicas dos participantes

\begin{tabular}{|c|c|c|c|c|c|c|}
\hline Criança $^{2}$ & Idade & Diagnóstico & $\begin{array}{l}\text { Cuidador- } \\
\text { familiar }^{2}\end{array}$ & $\begin{array}{l}\text { Renda } \\
\text { per } \\
\text { capita }\end{array}$ & Região de origem & Religião \\
\hline Pablo & $7 \mathrm{a} 6 \mathrm{~m}$ & Neuroblastoma IV & Paula (Mãe) & $\begin{array}{l}\text { Renda } \\
\text { variável }\end{array}$ & $\begin{array}{l}\text { Região Centro-Oeste } \\
\text { (1.400 km de } \\
\text { Campinas) }\end{array}$ & Católica \\
\hline Gabriel & $10 \mathrm{a} 0 \mathrm{~m}$ & LLA Pré-B - AR & Giovana (Mãe) & $\mathrm{R} \$ 400$ & $\begin{array}{l}\text { Região Sudeste } \\
\text { (30 km de Campinas) }\end{array}$ & Católica \\
\hline Renata & $5 \mathrm{a} 2 \mathrm{~m}$ & Neuroblastoma IV & Ricardo (Pai) & $\mathrm{R} \$ 300$ & $\begin{array}{l}\text { Região Norte } \\
\text { (3.400 km de } \\
\text { Campinas) }\end{array}$ & Católica \\
\hline Valentim & $7 \mathrm{a} 1 \mathrm{~m}$ & LLA & Vera (Mãe) & $\mathrm{R} \$ 100$ & $\begin{array}{l}\text { Região Norte } \\
\text { (3.800 km de } \\
\text { Campinas) }\end{array}$ & Católica \\
\hline Igor & $9 \mathrm{a} 3 \mathrm{~m}$ & Neuroblastoma IV & Isa (Mãe) & $\mathrm{R} \$ 156$ & $\begin{array}{l}\text { Região Sudeste } \\
\text { (200 km de Campinas) }\end{array}$ & Evangélica \\
\hline Júlia & $7 \mathrm{a} 9 \mathrm{~m}$ & Neuroblastoma IV & Juliana (Mãe) & $\mathrm{R} \$ 214$ & $\begin{array}{l}\text { Região Sudeste } \\
\text { (80 km de Campinas) }\end{array}$ & Católica \\
\hline André & $10 \mathrm{a} 1 \mathrm{~m}$ & Meduloblastoma AR & Ana (Mãe) & $\mathrm{R} \$ 273$ & $\begin{array}{l}\text { Região Sudeste } \\
\text { (100 km de Campinas) }\end{array}$ & Católica \\
\hline José & $10 \mathrm{a} 8 \mathrm{~m}$ & LLA - AR & Rosa (Avó) & $\mathrm{R} \$ 375$ & $\begin{array}{l}\text { Região Sudeste } \\
\text { (45 km de Campinas) }\end{array}$ & Evangélica \\
\hline
\end{tabular}

\subsection{Pré-análise}

Como etapa preliminar de análise de conteúdo temática, serão apresentados, a seguir, os excertos de falas mais significativos, agrupados de acordo com as categorias temáticas.

\subsubsection{Vivências dos cuidadores-familiares}

\subsubsection{Vivências emocionais no percurso diagnóstico}

Quando adoeceu, ele tava vomitando muito... Levei ele no postinho e disseram que ele tava com virose... Passou um mês e ele não melhorava... Teve febre e levei no hospital que eu trabalhava,

\footnotetext{
${ }^{2}$ Foram utilizados nomes fictícios para preservação da identidade das crianças e dos cuidadores-familiares.
} 
disseram que ele tava com pneumonia e receitaram um monte de antibióticos, mas a febre não passou... Ele foi ficando pálido, a barriga inchou e essas glândulas do pescoço também... Pensaram que podia ser leptospirose e pediram uns exames para confirmar... Quando eu voltei pra buscar o exame, percebi diferença no tratamento da equipe comigo, estavam mais carinhosos, cuidadosos, sabe? A médica chegou e disse que tinha uma alteração no exame e encaminhou pro Boldrini... Eu chorei até, porque fiquei muito assustada, eu já tinha ouvido falar do hospital e do que tratava aqui... Ela disse que era cedo pra falar alguma coisa, que ele precisava ser avaliado aqui no Boldrini primeiro... (Giovana, 34 anos, mãe do Gabriel)

Mas aí com três anos quando ia subir a ladeira ela começou a sentir fraqueza nas pernas... E com uns três anos e meio começou a sentir dores, a não comer... Ai que eu levei ela no médico pra ver o que tava acontecendo e começou a tratar infecção de urina, anemia... (Ricardo, 32 anos, pai da Renata)

E eu já tinha comprado um monte de antibiótico pra ela e nada, assim, de ficar boa... Aí quando foi um dia, eu pedi pra ele internar, porque já tava avançando, né, pedi pra ele internar... (Ricardo, 32 anos, pai da Renata)

E fazia exame, não dava nada... Só no último exame que deu, deu que era câncer mesmo... E na barriga mesmo... Da barriga passou pra perna e ai deu isso... E direto já veio pra cá e começou o tratamento... (Joana, 37 anos, mãe da Júlia)

Ele começou a sentir dor de cabeça que nunca tinha tido e o médico disse que era sinusite... Aí começou o tratamento, mas só piorava a dor... Começou a vomitar, ter febre e ficou estrábico... (Ana, 36 anos, mãe do André)

Levei ele em vários especialistas e nada... Tudo que eu queria era encontrar um médico que me dissesse "O A tem isso", eu rezava por isso todo dia... Eu só queria um caminho para poder curar meu filho... (Ana, 36 anos, mãe do André)

Ele tinha uma dor na perna e a mãe dele achava que era manha dele... Nem levava no posto nada... E depois que foi descobrir... (Rosa, 53 anos, avó materna do José)

\subsubsection{Repercussões psicológicas do diagnóstico oncológico}

Ele foi muito bem-vindo e aguardado pela família toda... E é isso que me faz perguntar "Da onde um câncer?" Nunca imaginei que uma criança tão desejada fosse ter tanto problema... (Paula, 39 anos, mãe do Pablo)

Ele tinha 97\% do sangue com leucemia... Nossa, foi muito dificil, eu não esperava que isso fosse acontecer... Nunca... Lá no hospital eu trabalhava na farmácia e fechava a conta de pacientes que faziam quimioterapia... Morria de dó de ver os pacientes, o sofrimento deles e das famílias... Nunca imaginava que ia passar por isso também... (Giovana, 34 anos, mãe do Gabriel)

No começo para mim foi mais dificil, né? Porque o V., quando eu descobri, tinha 1 ano e 7 meses. Então, ele fez todo o tratamento, tratou, fez todo o processo que era para fazer e, depois de um período, a doença voltou. Depois de todo tratamento, a doença voltou. (Vera, 33 anos, mãe do Valentim)

Quando eu ouvi foi difícil, foi difícil quando o médico deu o diagnóstico, eu achava que era o fim, eu tinha certeza que I. morria, ai eu fui vendo as histórias, cada dia eu tinha um pouco mais de esperança, mas quando acabou eu pensava "Meu Deus, se um dia a doença voltar, e de fato voltou, pra mim vai ser mais triste, porque eu já sei o que as crianças passam e eu já sei o que ele passou e o que ele vai ter que passar tudo de novo" (Isa, 29 anos, mãe do Igor)

O maior medo que deu foi quando o médico fala do câncer, porque o câncer quando ele chega, ele chega para matar... Não é uma doença que você vai, você trata e vai embora... É uma 
doença que marca para sempre, mesmo que você fique curado, um ano, dois anos, vinte anos, tem que estar aqui... Então é isso... (Isa, 29 anos, mãe do Igor)

Foi um choque... Aceitar mesmo, até hoje não aceitei... Não tem como aceitar... Tem que conformar, mas não aceita... Você tem uma filha e vem esse problema... Não sabe da onde vem, né? Porque todos nós temos, né, mas uma criança é inocente, né? (Joana, 37 anos, mãe da Júlia)

No primeiro tratamento ele [pai] ficou à base de calmante, apavorado com o diagnóstico e a possibilidade de perder o A. ... (Ana, 36 anos, mãe do André)

Dificil, porque ela não aceitava... Mas eu falo pra ela, que na gravidez ela só queria comer miojo... (...) Não tem coisa que precisa... (Rosa, 53 anos, avó materna do José)

\subsubsection{Dificuldades advindas do tratamento}

Dá um desespero ver seu filho sem comer o dia todo! Quando ele diz que tem vontade de alguma coisa, eu dou mesmo! Trouxe lanche do Mc Donalds esse final de semana... Eu sei que não pode, que tem risco, mas ele já não pode tanta coisa! (Paula, 39 anos, mãe do Pablo)

O tratamento judia demais, é muito desgastante, muito sofrimento... (Paula, 39 anos, mãe do Pablo)

O Gabriel ora todo dia antes de dormir, pede pra Deus ajudar para ele não perder a veia e não ter que ser furado de novo... Isso deixa ele muito nervoso, ele odeia e sofre muito! (Giovana, 34 anos, mãe do Gabriel)

Depois de fazer a quimioterapia, a defesa cai e sempre acontece alguma coisa: já teve boca em carne viva, dedo infeccionado, febre, e ai, tem que internar... Ele chora porque não quer ficar internado, é menino, né? Quer brincar com os amigos, ficar em casa... (Giovana, 34 anos, mãe do Gabriel)

Então, teve tempos tranquilos, mas teve vez de eu achar que não ia levar a Renata pra casa... Porque de cada 8, só um escapa dessa infecção que ela teve... A hospitalar, sabe? Até a médica falou "Pai, eu pensei que o Sr. ia sem a Renata... Foi grave, gravíssimo"... (Ricardo, 32 anos, pai da Renata)

Porque a gente tá no tratamento, mas não é a mãe, né? A gente preocupa das pessoas falarem... (Ricardo, 32 anos, pai da Renata)

Ele gritava muito, gritava, gritava mesmo, de desespero, e muitas vezes me culpava, que eu era a culpada de ele tá lá, tomando isso... (Vera, 33 anos, mãe do Valentim)

Ah é dificil... Não sei, eles brincam, eles tão tudo com o rostinho feliz, mas os pais não estão... Aqui os pais é só faz de conta... Todo mundo, eu tenho certeza... A gente não pode chorar, a gente não pode... Porque eu tenho certeza que, se fosse pra chorar, aqui era um choro só... (Isa, 29 anos, mãe do Igor)

Ele era perfeito, até o ano passado ele não tinha nada, não reclamava de nada, era calmo, uma criança doce, que a partir do momento que ele ficou doente, aquele $N$. nunca mais eu vi... [E o que a sra. acha que mudou com o adoecimento?] Ele ficou revoltado, sem educação, desde que ele adoeceu... Não tem paciência de nada... Não sei... Assim que ele adoeceu e nós viemos para cá, ele já veio uma outra criança... (Isa, 29 anos, mãe do Igor)

Ele fez 36 sessões e isso interferiu no crescimento dele, causou hipotireodismo e uma catarata no olho direito... Isso é o que mais atrapalha, tá programando para operar... (Ana, 36 anos, mãe do André) 
No primeiro tratamento do André eu estava grávida da Melina... Aí não podia ficar com ele nas quimioterapias; vinha pra consulta e o pai entrava no ambulatório... (...) Era uma tortura ter que ficar longe! (Ana, 36 anos, mãe do André)

Tabela 4.

Distribuição da ocorrência das categorias temáticas por entrevista com os cuidadoresfamiliares

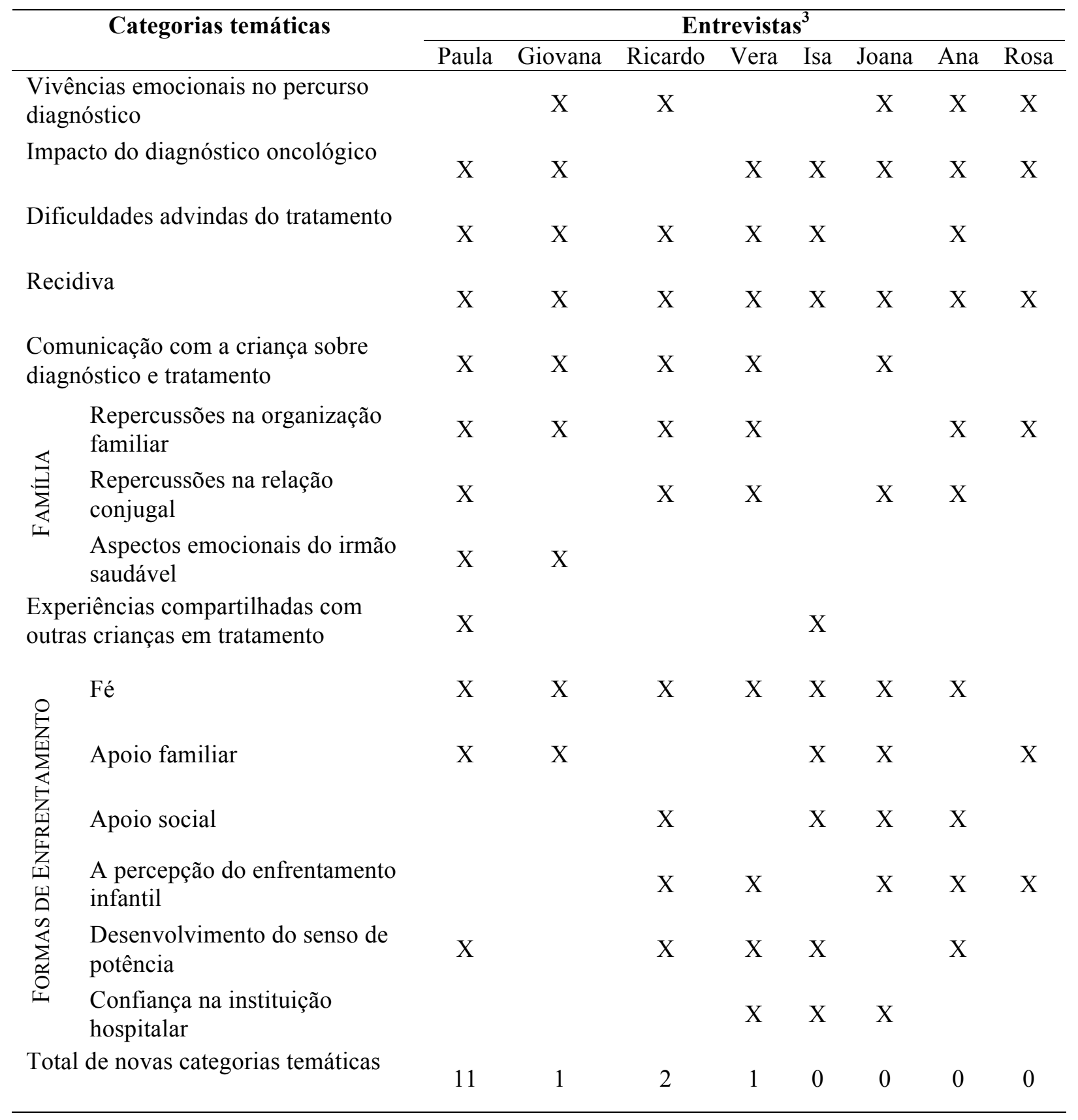

${ }^{3}$ Foram utilizados nomes fictícios para preservação da identidade dos cuidadores-familiares. 


\subsubsection{Experiências compartilhadas com outras crianças em tratamento}

A gente conheceu outras crianças que faziam o tratamento junto com o Pablo, que começaram junto com ele, mas morreram... E é duro, porque a gente fica muito próximo aqui... Um sabe do que tá acontecendo com o outro, fica na torcida, mas sofre junto também... (Paula, 39 anos, mãe do Pablo)

E acho que a experiência com o Igor [paciente falecido há 2 semanas] influencia... Eu tento separar as experiências, mas é diferente, porque quando se fala de câncer tudo é possivel... (Paula, 39 anos, mãe do Pablo)

Eu não tinha medo quando vinha para a consulta como amiga... O Paulo sim, se questionava se não ia acontecer com a gente [a recidiva, como com a outra criança], e eu dizia que ele era homem de pouca fé... Mas, no fim, minha fé que era tola... (Paula, 39 anos, mãe do Pablo)

A gente se apega em cada história pior que a da gente... Porque a gente sabe que se aquele que tá pior do que o meu tá ali, certeza que o meu vai estar... Aí quando você fica sabendo que um ali morreu, a gente pensa "mas ele tava tão bom... Tava bem que nem o meu... Ai, se ele morreu, o meu também vai morrer". Ai vem o medo... E ai vem de novo uma outra história, você já apega naquela, você morre, você já se apega na cura e assim, meu Deus, é uma tortura... (Isa, 29 anos, mãe do Igor)

Eu falei, esse lugar parece não ter fim... Porque desde que eu comecei aqui, as criançadas, os que não morreu, estão tudo aqui... "Ah menina, não acabei o tratamento, continuo na mesma coisa..." Então parece que a gente acha que nada vai mudar... Tem horas que eu acho que a vida vai ser essa aqui... Parece que não tem fim... Porque já era para a maioria dessas crianças não estar mais aqui... Porque parece que quanto mais gente vem, mais criança tem... (Isa, 29 anos, mãe do Igor)

E o sofrimento aqui é o dobro, porque você não sofre só pelo seu... Eu não sofro só pelo meu... Eu sofro por todos... (Isa, 29 anos, mãe do Igor)

\subsubsection{Recidiva}

Ai, a hora que a gente acha que vai, que ia voltar pra casa e se reorganizar, vem outra cacetada. Você acha que a gente dá conta? Ele ficou 5 meses fora de terapia e agora a gente vai recomeçar... (Paula, 39 anos, mãe do Pablo)

Ai agora, no segundo tratamento, eu tenho vontade de fazer tudo hoje, como se não fosse dar tempo de deixar pra depois... (Paula, 39 anos, mãe do Pablo)

Porque eu posso cuidar o tempo todo dai e fico perto... Vamos dar tudo para ele, fazer tudo, mas no fundo eu sei que não adianta... (Paula, 39 anos, mãe do Pablo)

Faço bem feita a minha parte, porque eu não quero ter culpa depois... Quero ter certeza de que fiz tudo que estava ao meu alcance e eu sei que estou fazendo... (Paula, 39 anos, mãe do Pablo)

Ia terminar em dezembro o tratamento, mas em outubro voltou a doença... Foi outro baque, bem pior do que na primeira vez, porque a gente tava contando os dias para acabar com aquilo tudo! (Giovana, 34 anos, mãe do Gabriel)

A gente tinha que esquecer da gente, para dar força para ele... Tentava esmagar meus sentimentos e todo o sofrimento para não passar para ele, mas quando eu não conseguia, saía de perto dele para chorar... Eu não gosto de fazer isso na frente dele... (Giovana, 34 anos, mãe do Gabriel) 
Foi uma conversa nada agradável, né? Mas não tem outro jeito... Primeiro a gente fica triste, tem que ficar mesmo... Fiquei uns três, quatro dias triste... Mas depois não adianta, né? Igual lá em Rio Branco, fiquei triste, mas depois fiquei alegre de pensar que ia tratar... E aqui a gente fica mais triste porque tá só eu e ela, né? Sozinho, sem saber o que vai acontecer... (Ricardo, 32 anos, pai da Renata)

Para mim, quando descobri o problema dele de novo, que tinha voltado, eu também quase entrei em depressão, engordei muito também. Quando a doença volta, a gente não quer acreditar, né? Então a gente cria uma barreira para nós também, de não querer, de não aceitar ou achar que vai perder, nada vai dar certo, então forma uma barreira negativa. (Vera, 33 anos, mãe do Valentim)

Para mim é muito triste... Ter que começar tudo de novo... E eu já sei o que é que a criança passa... Então fica difícil... Mas eu sei, que ele vai vencer... (Isa, 29 anos, mãe do Igor)

Saber que a doença voltou é pior do que ouvir pela primeira vez o médico dizer "Olha, seu filho tem câncer"... (Isa, 29 anos, mãe do Igor)

Ai quando eu vi que ela pediu esse eu pensei "Ela não vai pedir esse exame, se ela também não tem certeza... Eles também têm certeza... Eles só querem o exame porque decerto tem que apresentar para alguém"... É igual eu falei... Quando cai nesse lugar aqui, não existe suspeita... Existe certeza... (Isa, 29 anos, mãe do Igor)

Pra falar a verdade, não acredito ainda que voltou... Ela veio para um exame de rotina e descobriu... E ela não sentia nada, tava normal, não reclamava de dor, não teve febre, uma vez só ela teve febre nesse tempo... Mas eu levei lá, o médico examinou e disse que tava tudo em ordem com ela... Mas, fazer o que, né? A gente tem que fazer tudo que os médicos dizem, né, tem que acreditar que vai correr tudo bem... Às vezes dá vontade de largar mão, parar com tudo isso e deixar nas mãos de Deus, mas aí a gente quer ter ela com a gente, né? Então tem que tratar... (Joana, 37 anos, mãe da Júlia)

Foi um baque... A gente não esperava mais né? Depois de 4 anos... A gente já estava se preparando para a cura, porque ele já tava tratando com a Dra Z. [responsável pela Clínica Após o Término de Terapia, que mantém o acompanhamento a partir de 3 anos fora de tratamento], contando os meses para completar os 5 anos e receber o "atestado de curado"... (Ana, 36 anos, mãe do André)

Eu confio totalmente na equipe e faço o que eles disserem que vai ser o melhor, mas não é fácil recomeçar... Acho pior na segunda vez, porque você já sabe o que passou... E a gente sabe que fica menor a chance de cura agora, né? A luta é maior, e o medo também... O que tiver que ser será... (Ana, 36 anos, mãe do André)

Ah Foi em dezembro, né? A mãe dele ficou preocupada, porque ele foi parar até na UTI... Deu convulsão nele... Mas agora ele, graças a Deus, ele já tá bem, ai a gente fica mais tranquila... (Rosa, 53 anos, avó materna do José)

\subsubsection{Comunicação com a criança sobre diagnóstico e tratamento}

A gente não quer contar, porque ele sofre por antecipação só por saber que é "quimioterapia" e a gente acha que ele sofreria muito de saber que a doença voltou, "vou tratar para quê se não deu certo na primeira vez? " (Paula, 39 anos, mãe do Pablo)

Eu não conseguiria contar que a doença voltou... O Paulo também acha... É muito sofrimento desnecessário... (Paula, 39 anos, mãe do Pablo)

A gente não esconde nada dele, sabe? Até tentamos, risos, mas não dá... Ele é um menino muito esperto... (Giovana, 34 anos, mãe do Gabriel) 
A médica explicou que voltou... Não sei se ela entende direito, mas falo que tem que fazer a rádio pra poder ir pra casa e ela colabora muito... (Ricardo, 32 anos, pai da Renata)

No começo eu tinha um pouco de receio de dizer, assim olha, você tá fazendo um tratamento que você tem que tratar uma doença, então, tudo isso eu resguardava ele. Então a Dra. A. [psiquiatra] começou a conversar e falar para ele, mas no fundo eu não queria que ele soubesse... (Vera, 33 anos, mãe do Valentim)

Mas me abalava ouvir a voz dele falando "Eu faço um tratamento, eu tenho leucemia"... (Vera, 33 anos, mãe do Valentim)

A gente conversa, senta... Tem hora que a gente tem que falar a verdade: olha, você tem isso, isso, e aquilo outro, por isso tem que tomar isso... Eu explico tudo pra ela, os lugares que tem pelo corpo, só que ela não entende, né? Na cabecinha dela tudo é brincadeira... (Joana, 37 anos, mãe da Júlia)

\subsubsection{Implicações para a organização familiar}

Desde isso de não trabalhar, ter que vir no hospital e se desdobrar, até a presença do Paulo mesmo... Antes ele saía 5 h30 para trabalhar e voltava às $20 \mathrm{~h} . .$. Agora a gente fica $24 \mathrm{~h}$ juntos... Por um lado é bom, mas é estranho também... A convivência é maior, os atritos também... (Paula, 39 anos, mãe do Pablo)

Mas acho que depois que você vive com essa ameaça do câncer do seu filho, a gente muda a maneira de ver as coisas... Dá mais valor pras coisas mais simples, a gente vê tudo com outros olhos... (Paula, 39 anos, mãe do Pablo)

Acho que o adoecimento do Gabriel aproximou ela [sogra] da gente... Aliás, a família toda dele era distante... A minha não, sempre foram muito presentes e continuam assim... (Giovana, 34 anos, mãe do Gabriel)

A mãe dela não quis vir, né, a minha mãe é senhora já e não podia vir, até porque ela tem nervoso, né? E minha mãe não ia aguentar, porque não é todo mundo que aguenta... Inclusive, acho que nem a mãe da Renata ia aguentar... A médica até falou que normalmente quem vai é a mãe, mas eu disse que não é o caso da R. A mãe dela disse, "então vá você". (Ricardo, 32 anos, pai da Renata)

Foi dificil né? Você imagina, largar mulher, filha, trabalho, amigos, tudo lá no Acre e vir? Mas eu deixei bem claro pra ela "Olha, eu tô indo, mas pra cuidar da outra filha" e o importante é que ela tá bem e a outra também, ficou com a mãe... (Ricardo, 32 anos, pai da Renata)

A minha familia também, a gente começou a se unir mais... Nós somos irmãos assim: a gente briga, discute, mas na hora do problema a gente se une... (Vera, 33 anos, mãe do Valentim)

A gente vai revezando...Hoje eu vou dormir aqui, aí amanhã quando meu marido vier ele traz o Victório e eu volto com ele... Porque também tem que cuidar da casa, né? (Vera, 33 anos, mãe do Valentim)

Foi um baque para a família toda... (Ana, 36 anos, mãe do André)

Fico preocupada com o marido lá em casa... Mas agora essa semana, ela vem aqui ficar com o I e fica até ele sair... Porque eu que pago as contas, eu que tenho que ir no banco, tudo é eu... Ai fica mais difícil ficar aqui o tempo todo... (Rosa, 53 anos, avó materna do José) 


\subsubsection{Repercussões na relação conjugal}

Mas a parte sexual tá difícil... Ele tem que me entender como mãe... Não dá pra ter desejo vendo seu filho sofrer... (Paula, 39 anos, mãe do Pablo)

E ela me apoia de tá aqui, ela que me deu força de vir pra cá... Se fosse outra, não tava nem aí, mas ela graças a Deus entende e me dá força... (Ricardo, 32 anos, pai da Renata)

Então, às vezes, eu o culpava muito também, porque ele sempre enxergou meu filho doente, então a gente não se unia, a gente discutia, a gente brigava muito, ele me acusava, eu acusava ele, então, era uma maneira de acusação... Então eu sempre tive um peso nas costas de ouvir que o Valentim nasceu assim porque eu sou culpada, porque eu tinha uma anemia também, então ele me culpava, sempre tive um peso muito grande nas minhas costas... Uma pessoa que não confia em nada, não acredita em nada, ele tem que ver para ele acreditar, entendeu? (Vera, 33 anos, mãe do Valentim)

E tem hora que a gente perde a vontade até do casamento, sabe, não é fácil... Meu marido é muito calmo, ele me ajuda, se fosse outra pessoa nem estaria mais junto, mas ele não... (Joana, 37 anos, mãe da Júlia)

Ele ficou sem chão e bebe cada vez mais... tá sendo bem difícil manter nossa relação... E eu fico muito sobrecarregada... (Ana, 36 anos, mãe do André)

\subsubsection{Aspectos emocionais do irmão saudável}

É difícil dividir o tempo e os cuidados entre os dois... A Patrícia tem ciúmes, também quer a gente perto e acaba não tendo muito... Porque esse é um tratamento que exige muito cuidado, atenção redobrada, cuidados de limpeza, alimentação... Ela [irmã] acaba ficando sem a gente... A gente tenta, mas não tem jeito... Ai, ela começou a ter dificuldade na escola, a professora falou que pode ser pra chamar atenção... (Paula, 39 anos, mãe do Pablo)

Fica sempre sem a gente, sem o irmão, sem mim... tá terrível, desobediente, dando muito trabalho... Percebo que ele fica triste quando o Gabriel interna... É dificil... Tento ter mais paciência, mas não é fácil... (Giovana, 34 anos, mãe do Gabriel)

\subsubsection{Fé como estratégia de enfrentamento}

Eu penso “Meu Deus, ele teve fungo, mas ele tem o Senhor”... (Paula, 39 anos, mãe do Pablo)

A gente precisa ter alguma coisa para se apegar e Deus tá sempre presente nos momentos da nossa vida, principalmente nesses mais difíceis... Ele que nos dá força para seguir e acreditar que vai dar certo... (Giovana, 34 anos, mãe do Gabriel)

Eu peço que Deus me dê forças e mostre o caminho... (Giovana, 34 anos, mãe do Gabriel)

Graças a Deus, Deus nunca abandonou a gente... Por mais que a gente esteja só, a gente nunca tá sozinho, Ele sempre tá com a gente, tem que ter fé... Mesmo a gente não sendo nenhum santinho, né, porque eu não sou... Peço a Deus pra dar força pra gente, saúde pra ela, não só pra nós dois, mas pra todas as crianças que eu vejo... (Ricardo, 32 anos, pai da Renata)

Deus tem me dado muita força... Estou sendo uma mulher de fé que eu nunca imaginei ter a fé que eu tenho hoje... E quem conversa com o meu filho, graças a Deus, sente nele também a fé que ele tem agora, entendeu? Antes eu aconselhava ele, hoje quem me aconselha é ele... (Vera, 33 anos, mãe do Valentim) 
Então, eu falo para ele "Se Deus abriu as portas e mostrou o caminho, é este o caminho" A gente tem sempre que viver o hoje, que o amanhã, só a Ele pertence... E vamos fazendo a nossa parte... (Vera, 33 anos, mãe do Valentim)

Eu tenho muita fé... Minha fé, meu esposo, minha família... Os amigos, porque aqui a gente faz muita amizade... Isso que ajuda a superar... (Isa, 29 anos, mãe do Igor)

Mas eu ando muito nervosa... A gente tenta disfarçar, mas tem hora que eu falo tanta besteira, até brava com Deus, sabe? Essa história toda da doença... Dá mais raiva... (Joana, 37 anos, mãe da Júlia)

Às vezes dá vontade de largar mão, parar com tudo isso e deixar nas mãos de Deus, mas aí a gente quer ter ela com a gente, né? Então tem que tratar... (Joana, 37 anos, mãe da Júlia)

Eu sempre fui muito religiosa e nessas horas, só Deus dá força pra gente... (Ana, 36 anos, mãe do André)

\subsubsection{Apoio familiar como estratégia de enfrentamento}

O dinheiro pesa, mas o que mais pesa é o relacionamento, porque se um não apoiar o outro, não tem jeito... (Paula, 39 anos, mãe do Pablo)

Eles choraram bastante quando souberam da recidiva e tentam nos apoiar de alguma forma, mas tá todo mundo abalado... Mas vai passar, a gente sabe que uma hora tudo acaba... (Giovana, 34 anos, mãe do Gabriel)

Foi difícil demais para a família... Mas a gente se une e dá força para enfrentar... (Isa, 29 anos, mãe do Igor)

Eu tenho muita fé... Minha fé, meu esposo, minha familia... Os amigos, porque aqui a gente faz muita amizade... Isso que ajuda a superar... (Isa, 29 anos, mãe do Igor)

A família continua unida, um ajudando o outro, dando força para a luta... (Joana, 36 anos, mãe da Júlia)

Nessas horas que dá vontade de desistir, ele [esposo] fala que não pode, que vai dar tudo certo, me dá esperança, né... (Joana, 36 anos, mãe da Júlia)

Mas agora essa semana, ela vem aqui ficar com o José e fica até ele sair... Porque eu que pago as contas, eu que tenho que ir no banco, tudo é eu... Aí fica mais dificil ficar aqui o tempo todo... (Rosa, 53 anos, avó materna do José)

Eu também ficava preocupada... Eu que acompanhei mais... Não tinha ninguém pra revezar... (Rosa, 53 anos, avó materna do José)

\subsubsection{Apoio social como estratégia de enfrentamento}

Não foi fácil não... O primeiro mês, segundo mês, terceiro mês foi muito difícil... Mas aí a pessoa vai fazendo amigos e vai dando um jeito de levar... (Ricardo, 32 anos, pai da Renata)

Eu tenho muita fé... Minha fé, meu esposo, minha família... Os amigos, porque aqui a gente faz muita amizade... Isso que ajuda a superar... (Isa, 29 anos, mãe do Igor)

Antes ele [esposo] viajava muito, né, mas o patrão dele deixou ele agora na sede, tomando conta das coisas, do que entra e sai, pra ficar mais perto da Júlia no tratamento... (Joana, 37 anos, mãe da Júlia) 
Os amigos do bairro ajudam também, rezam pelo A e por nós, alivia poder compartilhar o que a gente passa... Mas a experiência é diferente, só quem vive sabe o que é... (Ana, 36 anos, mãe do André)

\subsubsection{A percepção do enfrentamento infantil como estratégia de enfrentamento}

E eu sei que tem muitos casos piores que o dela, vejo muita criança na cadeira de rodas, outros intubados, na máquina... Por isso tudo, eu vejo que ela tá boa, tá brincando, pulando, então tá bem, né? (Ricardo, 32 anos, pai da Renata)

Tem dia que acorda meio assim, mas logo tá dançando como se não tivesse tomado nada que fizesse ele fica mal... Ele me dá essa alegria... (Vera, 33 anos, mãe do Valentim)

Às vezes fico nervosa e falo "Júlia você tem que comer, se não você morre, tem que fazer o tratamento", e ela diz "ai, mãe, mas o que, não vai morrer! Imagina morrer! Não morre nada" e dá animação pra gente, né? Porque a gente fica lá pra baixo, a gente tenta ter força, mas tem hora que não dá... (Joana, 37 anos, mãe da Júlia)

Mas ela não tem medo de nada não... E é isso que dá força pra gente, esse jeito dela de enfrentar... (Joana, 37 anos, mãe da Júlia)

Senti um alivio enorme quando acabou e o médico falou que ele já estava na sala de recuperação... E ele acordou já me pedindo os hominhos dele, risos. Ele tava brincando antes de entrar na cirurgia e depois da anestesia deram os hominhos para mim, porque não podia entrar lá... Eu fui rindo pegar os brinquedos, pensando que meu filho tava bom, né? (Ana, 36 anos, mãe do André)

Graças a Deus tá bem agora, mas ele ficava revoltado... (Rosa, 53 anos, avó materna do José)

No começo era mais difícil, mas agora tá terminando já, né... tá contente... (Rosa, 53 anos, avó materna do José)

\subsubsection{Desenvolvimento do senso de potência como estratégia de enfrentamento}

Segui todas as orientações médicas à risca, tudo nos mínimos detalhes... Mas conseguimos controlar... Às custas de muita preocupação, sabe... (Paula, 39 anos, mãe do Pablo)

Investi muito na amamentação, porque sabia dos beneficios do leite materno... Ele mamava a cada 1 hora, até os 8 meses de idade... Só o peito! Eu sempre fiz tudo que diziam ser bom pro bebê... (Paula, 39 anos, mãe do Pablo)

A pessoa aprende a estudar, aprende outras coisas, eu também não sabia de nada não, aqui que eu tô aprendendo... A pessoa aprende, o mundo ensina... (Ricardo, 32 anos, pai da Renata)

Fico tranquila, porque acho que tudo vai do nosso tratamento também, como a gente trata ele, da alimentação, tudo isso ajuda muito... E a gente tem que evitar muitas coisas... Eu tenho conversado muito com ele, porque ele quer ficar lá fora, quer ficar brincando, então eu digo que tem que ter um limite para tudo... (Vera, 33 anos, mãe do Valentim)

Eu fiquei sim contente com esse elogio [da médica], porque é uma coisa assim que ela tem visto no Valentim, que meu tratamento e o amor assim que a gente dá para ele, tudo ajuda no tratamento... (Vera, 33 anos, mãe do Valentim)

Aí eu pensei: "O carocinho, a dor de cabeça e a dor no ombro do mesmo lado? Uhm" Aí eu trouxe ele de volta e disse para eles: "Eu quero saber o que é isso... Porque qualquer coisa que seja, tem um tratamento... (Isa, 29 anos, mãe do Igor) 
Fiquei muito preocupada, então observava tudo! Procurava sequelas ou qualquer sinal diferente, mas graças a Deus, não achei nada grave... (Ana, 36 anos, mãe do André)

\subsubsection{Confiança na instituição hospitalar como estratégia de enfrentamento}

E aqui não, aqui as pessoas têm um carinho pelos pacientes, se preocupam com os pacientes... Então, tem horas que a gente descobre que os médicos estão fazendo coisas que a gente não imaginava que eles tavam fazendo, cuidando... (Vera, 33 anos, mãe do Valentim)

$\dot{E}$, porque é o melhor lugar do mundo e, ao mesmo tempo, o pior lugar que possa existir... Ele é as duas coisas, ele é bom e ruim... Um dia tá pior, outro é o melhor que podia ter... E são esses dias que fazem a gente continuar... (Isa, 29 anos, mãe do Igor)

Mas aqui é um hospital muito bom, não tem nenhuma reclamação... Dá mais força pro tratamento... Os médicos tentam de tudo, né, o que eles podem fazer no alcance deles, né? Deve ser duro pra eles também ver tanta coisa, né? (Joana, 36 anos, mãe da Júlia)

\subsubsection{Vivências das crianças em tratamento da recidiva oncológica}

\subsubsection{Percepção de ameaças}

Tá sentindo que vai chover (Pablo, 7 anos e 6 meses, Desenho-Estória 2)

(...) porque se chove a lama vai aumentar muito e onde a galinha está vai alagar... (Gabriel, 10 anos, Desenho-Estória 1)

Esse aqui é o tubarão... E esse é o pato... O tubarão tá atrás do pato... (Renata, 5 anos e 2 meses, Desenho-Estória 1)

Esse é o peixe, o peixe-espada... Olha o bico dele... [E o que ele faz com esse bico?] Ele fura... (Renata, 5 anos e 2 meses, Desenho-Estória 1)

Ela vai voar! [Vai voar?] É, lá pra floresta! [E o que tem nessa floresta?] Tem o lobo mau... Aí ela foi lá no lobo mau... Ela foi visitar a vovozinha... Aí quando o lobo pede para ela pegar uma flor, ele chega rápido e ai come a vovozinha... [Ele come a vovozinha? E o que ela sente?] Ela fica com medo... (Renata, 5 anos e 2 meses, Desenho-Estória 2)

Aí, a bruxa não foi convidada para a festa, aí joga um encanto assim: "Essa menina entrará no castelo, enfiará o dedo numa roca e morrerá". Ai, mas a bruxa azul consegue tirar o encanto, assim "Ela não morrerá, mas dormirá num sono profundo até que um beijo a acordará" (Valentim, 7 anos e 1 mês, Desenho-Estória 1)

É assim, ele tem uma irmã, aí pega, né, ela vai atravessar o rio numa corda... Primeiro ela atravessa, depois ele... Ai depois, eles vão voltar para o outro caminho, que vai ter outra corda para atravessar, ai quando ela vai atravessar, a corda cai, ai ela se afoga e ela morre... (Valentim, 7 anos e 1 mês, Desenho-Estória 2)

Preguiça, eu sei um bom remédio para tirar isso ai dela... Um banho, gelado... Mas se ela tomar banho, ela derrete... [Derrete?] E vai pro esgoto... [E o que acontece?] Ela fica em pedacinho... (Valentim, 7 anos e 1 mês, Desenho-Estória 3)

Ai a gosma desaparece e não aparece nunca mais... [E aí?] Aí ela vai para o esgoto e fica lá com os ratos... (Valentim, 7 anos e 1 mês, Desenho-Estória 3) 
Não é bom isso, porque dai os pés viram fantasmas! (Valentim, 7 anos e 1 mês, DesenhoEstória 4)

Já pensou se tivesse um furacão de água? [O que iria acontecer?] Ia afogar todo mundo! [E aí? Como eles iam ficar?] Afogados, eles iam morrer... (Valentim, 7 anos e 1 mês, Desenho-Estória 5)

Chuva! Aqui é o raio atingindo! [O raio atinge eles?] Não, atinge a Terra... [Ah... E o que acontece?] Depois ele some... (Valentim, 7 anos e 1 mês, Desenho-Estória 5)

Quando chegou em casa, a mãe fez um e jogou os outros pela janela, aí nasceu um pé de feijão que cresceu até aqui no céu e destruiu a casa... O João subiu no pé de feijão e chegou no castelo do gigante... O gigante viu ele e ele teve que sair correndo! (Igor, 9 anos e 3 meses, Desenho-Estória 1)

Um cara que fez as coisas ruins e veio um raio e matou ele... Se mata alguém, a carne vai secando, secando, até virar pó... (Igor, 9 anos e 3 meses, Desenho-Estória 2)

É... Tem gente querendo destruir a casa para construir outra... Porque essa casa é antiga... Querem fazer uma nova... (Igor, 9 anos e 3 meses, Desenho-Estória 4)

Tá sol, mas aqui vem a chuva, oh... Tá frio... (Júlia, 7 anos e 9 meses, Desenho-Estória 3)

É uma guerra... Eles estão tentando invadir o castelo... (André, 10 anos e 1 mês, DesenhoEstória 2)

\subsubsection{Vulnerabilidade e senso de desproteção}

Todo mundo vai se esconder em casa, o pato vai também, ele não vai ficar aqui fora sozinho! (Pablo, 7 anos e 6 meses, Desenho-Estória 2)

Tá chovendo muito e ela iria molhar o vestido, né? (Gabriel, 10 anos, Desenho-Estória 2)

E eu vou desenhar o rabo... Olha o rabo... O rabo dela não encaixou direito, olha... [Não encaixou direito? E aí?] Ai vai virar uma abelha! Ela tem essa asa pequenininha e essa asa grandona... [Olha, uma asa é maior que a outra... E o que vai acontecer?] Ela vai voar! [Vai voar?] É lá pra floresta! [E o que tem nessa floresta?] Tem o lobo mau... Aí ela foi lá no lobo mau... (Renata, 5 anos e 2 meses, Desenho-Estória 2)

O dedo vai ser tudo aberto, risos [Vai ficar aberto? E o que acontece?] Aparece o osso do pé... [E aí, Valentim?] Fica vazando sangue pela casa... Ai a pessoa morre! (Valentim, 7 anos e 1 mês, Desenho-Estória 4)

Eles passavam muita fome (...) (Igor, 9 anos e 3 meses, Desenho-Estória 1)

[E o que é o mais difícil de morar na ilha?] Ter toda essa água em volta... [Uhm... É difícil?] É... Porque quando quer as coisas, fica muito dificil atravessar... (Igor, 9 anos e 3 meses, Desenho-Estória 3)

É um carro de polícia... Ele entrou numa corrida... [Uma corrida?] É... Sozinho... Uma corrida contra o tempo... (...) Não sei o que acontece... É uma história sem final... Precisa esperar para ver o que vai acontecer... (André, 10 anos e 1 mês, Desenho-Estória 1)

[E como vai chamar sua história?] Não sei... [Você pode dar o nome que quiser...] Eu não sei... Só dá pra saber depois... [Como assim?] Não dá pra saber ainda... (André, 10 anos e 1 mês, Desenho-Estória 2) 
Tabela 5.

Distribuição das categorias temáticas por conjunto de Desenhos-Estórias realizado com as crianças

\begin{tabular}{|c|c|c|c|c|c|c|c|c|}
\hline \multirow{2}{*}{ Categorias } & \multicolumn{8}{|c|}{ D-E ${ }^{4}$} \\
\hline & Pablo & Gabriel & Renata & Valentim & Igor & Júlia & André & José \\
\hline Percepção de ameaças & X & X & X & X & X & X & X & \\
\hline $\begin{array}{l}\text { Vulnerabilidade e senso de } \\
\text { desproteção }\end{array}$ & $\mathrm{X}$ & $\mathrm{X}$ & $\mathrm{X}$ & $\mathrm{X}$ & $\mathrm{X}$ & & $\mathrm{X}$ & $\mathrm{X}$ \\
\hline Percepção de fragilidade no outro & X & & X & X & & & & $\mathrm{X}$ \\
\hline Relação entre o bem e o mal & & & $\mathrm{X}$ & $\mathrm{X}$ & $\mathrm{X}$ & & & \\
\hline Despersonalização & & $\mathrm{X}$ & & $\mathrm{X}$ & $\mathrm{X}$ & & & \\
\hline Busca de proteção & $\mathrm{X}$ & $\mathrm{X}$ & $\mathrm{X}$ & $\mathrm{X}$ & $\mathrm{X}$ & & $\mathrm{X}$ & $\mathrm{X}$ \\
\hline Busca por relacionamentos afetivos & X & $\mathrm{X}$ & X & $\mathrm{X}$ & & & $\mathrm{X}$ & \\
\hline Percepção de restrição & & $\mathrm{X}$ & & $\mathrm{X}$ & & & & \\
\hline Perdas ao longo da vida & $\mathrm{X}$ & & & $\mathrm{X}$ & & & & $\mathrm{X}$ \\
\hline Autoestima & & $\mathrm{X}$ & & & & & $\mathrm{X}$ & \\
\hline $\begin{array}{l}\text { Percepção de recursos de } \\
\text { enfrentamento }\end{array}$ & $X$ & $\mathrm{X}$ & $\mathrm{X}$ & $\mathrm{X}$ & $\mathrm{X}$ & $\mathrm{X}$ & & $\mathrm{X}$ \\
\hline $\begin{array}{l}\text { Projeção de situações de crescimento } \\
\text { e conforto emocional }\end{array}$ & $\mathrm{X}$ & $\mathrm{X}$ & $\mathrm{X}$ & $\mathrm{X}$ & & $\mathrm{X}$ & & \\
\hline Total de novas categorias temáticas & 8 & 3 & 1 & 0 & 0 & 0 & 0 & 0 \\
\hline
\end{tabular}

\subsubsection{Percepção de fragilidade no Outro}

Esse é meu avô [Seu avô?] Pai da minha mãe. (...) [E quantos anos ele tem?] Nem sei, já tá de dentadura! (Pablo, 7 anos e 6 meses, Desenho-Estória 1)

Ai quando o lobo pede para ela pegar uma flor, ele chega rápido e aí come a vovozinha... (Renata, 5 anos e 2 meses, Desenho-Estória 2)

No começo, é assim, o pai dela vai pra bem longe, mas só que ele encontra um castelo, ele fica perdido... (Valentim, 7 anos e 1 mês, Desenho-Estória 1)

Ai depois, eles vão voltar para o outro caminho, que vai ter outra corda para atravessar, ai quando ela vai atravessar, a corda cai, ai ela se afoga e ela morre... Ai vai ter que enterrar ela, todo mundo fica desesperado...(Valentim, 7 anos e 1 mês, Desenho-Estória 2)

\footnotetext{
${ }^{4}$ Foram utilizados nomes fictícios para preservação da identidade das crianças.
} 
Ela morre porque a corda cai, aí quando a corda caiu, ele tentou encontrar ela, mas ele não conseguiu encontrar... Aí ele pensou que ela ficou perdida na mata, mas só que ela morreu... Ai quando soubem que ela morreu, foram enterrar ela e ficou só ele... ...(Valentim, 7 anos e 1 mês, Desenho-Estória 2)

Mas o motor do carro dela às vezes não pega... Porque fica muito tempo parado o carro... Aí não liga... Precisa trocar a bateria, mas é longe o lugar que troca, aí ela não conseguiu ir lá ainda... (José, 10 anos e 8 meses, Desenho-Estória 3)

\subsubsection{Relação entre o bem e o mal}

Esse [peixe-espada] é amigo desse [pato] e ai ele vai picar o tubarão, porque o tubarão é mau... [Ele é mau? E o que faz dele mau?] Ele quer pegar o pato... (Renata, 5 anos e 2 meses, Desenho-Estória 1)

Ai o pai da chapéu vermelho tem um negócio assim e o lobo mau fica com muito medo do pai da chapéu vermelho... (Renata, 5 anos e 2 meses, Desenho-Estória 2)

Ela [bruxa] vai tentar virar um dragão para não deixar que o príncipe pegue ela [Rapunzel], mas se ele conseguir matar a bruxa, ele consegue pegar a Rapunzel de primeira. (Valentim, 7 anos e 1 mês, Desenho-Estória 1)

"Fecha os olhos", que aparece um gigante, mas é do mal não, é do bem... (Valentim, 7 anos e 1 mês, Desenho-Estória 2)

Mas ai eles encontram um monte de bichinhos, só que é besouro do mal, besouro falante, aí eles enfrentam a águia, enfrentam o porco-espinho, os besouros, e enfrentam o gavião. [E como é a luta?] A luta é assim: eles lutam sem nada, mas só que o cara tem escudo e uma arma. Assim, a arma de espada, assim, eles vão lutar com os bichos... (Valentim, 7 anos e 1 mês, Desenho-Estória 2)

Eles [fantasmas] assustam os destruidores para proteger a casa... São maus para eles, mas bons pra casa, né? (Igor, 9 anos e 3 meses, Desenho-Estória 4)

\subsubsection{Despersonalização}

Ele é só o personagem... Se você quer saber da vida desse cowboy, ele é Woody Irrá. (Gabriel, 10 anos, Desenho-Estória 3)

Eu não sei da vida da gosma [Como ela se sente?] Eu não sei da vida da gosma [Consegue imaginar?] Não... (Valentim, 7 anos e 1 mês, Desenho-Estória 3)

Eu não sei da vida dos fantasmas... (Valentim, 7 anos e 1 mês, Desenho-Estória 4)

Eles são da mesma família de coqueiro... (Igor, 9 anos e 3 meses, Desenho-Estória 3)

\subsubsection{Busca de proteção}

[Pega os lápis de cor e constrói uma casa sobre o papel] Pronto! Deu certo! [Agora eles estão protegidos?] Agora sim. (Pablo, 7 anos e 6 meses, Desenho-Estória 2)

Vou fazer uma casinha para os porquinhos se protegerem da chuva e vai ter lama, chiqueiro tem que ter lama! (Gabriel, 10 anos, Desenho-Estória 1) 
Essa não vai ter ponte levadiça não... Vou colocar uma barra de proteção, vai saber se um ladrão vai querer entrar, num castelo desses, né? (Gabriel, 10 anos, Desenho-Estória 2)

Aqui morava uma linda princesa, que o pai não deixa sair de casa, mas também não é hora de sair... (Gabriel, 10 anos, Desenho-Estória 2)

Ai o pai da chapéu vermelho tem um negócio assim e o lobo mau fica com muito medo do pai da chapéu vermelho... (Renata, 5 anos e 2 meses, Desenho-Estória 2)

Aí eles constroem uma casa na árvore, por exemplo, vem um ladrão, aí eles sobem para a casa na árvore... Eu sempre quis construir uma casa na árvore... (Valentim, 7 anos e 1 mês, Desenho-Estória 2)

Eles [fantasmas] assustam os destruidores para proteger a casa... São maus para eles, mas bons pra casa, né? [E o que acontece?] Eles desistem de destruir a casa, porque têm medo de chegar perto... (Igor, 9 anos e 3 meses, Desenho-Estória 4)

Eles não deixaram ser invadido... Eles trancaram os portões para não deixar ninguém entrar... (André, 10 anos e 1 mês, Desenho-Estória 2)

Não pode jogar nada na natureza e também não pode poluir... Tem que cuidar... (José, 10 anos e 8 meses, Desenho-Estória 1)

Fica assim, tem hora que [o carro] não pega, até alguém cuidar disso, né? Tem que levar na oficina... (José, 10 anos e 8 meses, Desenho-Estória 3)

\subsubsection{Busca por relacionamentos afetivos}

Aqui tá todo mundo junto, a familia inteira. (Pablo, 7 anos e 6 meses, Desenho-Estória 2)

Esse é o dono dessa fazenda toda, que cuida da galinha, da ovelha, do porquinho e do cavalo... (Gabriel, 10 anos, Desenho-Estória 2)

Precisa dos amigos, de atenção e nunca ficar solitário. [Solitário?] É... Ele não gosta de ficar sozinho... Com os amigos fica bem melhor... (Gabriel, 10 anos, Desenho-Estória 3)

Esse é o peixe e essa é a baleia... Ela é amiga dele e ele é amigo dele (peixe espada) e ele é amigo dele (pato). Esse é outro peixe... Ele é amigo deles e fica amigo do tubarão... Ai todos ficam felizes para sempre... (Renata, 5 anos e 2 meses, Desenho-Estória 1)

Ai o pai da chapéu vermelho tem um negócio assim, e o lobo mau fica com muito medo do pai da chapéu vermelho... (Renata, 5 anos e 2 meses, Desenho-Estória 2)

Ai ele vai subindo pelas escadas, ai dá um beijo nela e eles se casam... Eles se apaixonam... (Valentim, 7 anos e 1 mês, Desenho-Estória 1)

$\dot{E}$ assim, primeiro tu tá indo pro baile... Aí se encontra com alguém, eu não sei dizer muito, tá? [Não se preocupe... A história é sua, pode ser do jeito que você quiser] Depois você conheceu alguém... Tu fica simpática... Aí depois vai embora para casa, aí depois se encontra com ele de novo... Aí depois você ficava e aí namorava... (Valentim, 7 anos e 1 mês, Desenho-Estória 2)

Isso aqui que eu fiz é uma cartinha, pra ti... Uma cartinha que eu fiz... [E que história essa carta conta?] Não tem história nenhuma não... Não sei... Eu sou muito criança para entender essas coisas... (Valentim, 7 anos e 1 mês, Desenho-Estória 2)

Ela gosta mais de flor... Quer ficar perto da flor ... (Júlia, 7 anos e 9 meses, Desenho-Estória 1)

Outras pessoas... Não foram só eles [que trancaram o portão]... (André, 10 anos e 1 mês, Desenho-Estória 2) 


\subsubsection{Percepção de restrição}

Aqui morava uma linda princesa, que o pai não deixa sair de casa, mas também não é hora de sair... Tá chovendo muito e ela iria molhar o vestido, né? Mas nem eu saio daqui, fico só nesse quarto de hospital, sem videogame... Continuando... Ela não saía por nada, ela gostava de ficar no castelo, tinha lindas flores uma de cada cor da natureza... [E como ela se sente?] Triste, é uma tortura! (Gabriel, 10 anos, Desenho-Estória 2)

Ai depois que costurou o pé fica de repouso... Ai depois quando sarou, ele e pode brincar... [E a dor?] Passou... [E o que ele achou de ficar de repouso?] Nada bom... Não podia se mexer, não podia nada! Foi assim que eu fiquei... (Valentim, 7 anos e 1 mês, Desenho-Estória 4)

\subsubsection{Perdas ao longo da vida}

Nem sei, já tá de dentadura! (Pablo, 7 anos e 6 meses, Desenho-Estória 1)

[E quantos anos tem esses pés?] Uns 1030... [Eles são mais velhos, então...] Não é bom isso, porque dai os pés viram fantasmas! (Valentim, 7 anos e 1 mês, Desenho-Estória 4)

Agora vou desenhar o carro da minha avó... [desenha carro, detalhes, escapamento e fumaças] Mas o motor do carro dela às vezes não pega... Porque fica muito tempo parado o carro... Ai não liga... Precisa trocar a bateria, mas é longe o lugar que troca, aí ela não conseguiu ir lá ainda... (José, 10 anos e 8 meses, Desenho-Estória 3)

\subsubsection{Autoestima}

Ele está olhando o lindo trabalho que acabou de fazer, a linda galinha, as quatro ovelhas, o porquinho e o lindo cavalo... (Gabriel, 10 anos, Desenho-Estória 1)

Deu pra fazer uma princesinha bem humilde... Não é aquela de artista, mas também eles são muito exagerados... (Gabriel, 10 anos, Desenho-Estória 2)

Quando não é muito bonito por fora, é muito bonito por dentro, grande, grande... (Gabriel, 10 anos, Desenho-Estória 2)

Pensando em como tá o desenho, preocupado... (Gabriel, 10 anos, Desenho-Estória 3)

Eu gosto de contornar primeiro, para não borrar... (André, 10 anos e 1 mês, Desenho-Estória 2)

\subsubsection{Percepção de recursos de enfrentamento}

[Pega os lápis de cor e constrói uma casa sobre o papel] Pronto! Deu certo! [Agora eles estão protegidos?] Agora sim. (Pablo, 7 anos e 6 meses, Desenho-Estória 1)

Ela é amiga dele e ele é amigo dele [peixe espada] e ele é amigo dele [pato]. Esse é outro peixe... Ele é amigo deles e fica amigo do tubarão... Ai todos ficam felizes para sempre... (Renata, 5 anos e 2 meses, Desenho-Estória 1)

Ele não gosta de ficar sozinho... Com os amigos fica bem melhor... (Gabriel, 10 anos, DesenhoEstória 3) 
Não se preocupa não... [Desenha um guarda-chuva] Porque eles têm um guarda-chuva... (Valentim, 7 anos e 1 mês, Desenho-Estória 5)

Mas tem jeito de costurar... Já fez cirurgia? [Não] É fácil, eu já fiz cirurgia ... Eles abrem o pé, por exemplo aqui... A pessoa tem um tumor, né? Ai eles pegam, abrem o corpo da pessoa, aí tira aquele bichinho lá e joga fora ... Aí eles veem naquele binóculo lá, como é? [Microscópio?] $E$ É o bichinho que tem... Ai eles pegam e costuram com agulha o que eles fizeram e aqui fica costurado... Ai tem que ficar de repouso um tempão de dias... [E depois, o que acontece?] Depois quando sara, some aquela cirurgia, ai pode brincar o tanto que você quiser... (Valentim, 7 anos e 1 mês, Desenho-Estória 4)

Ele corta a árvore com um machado, para não deixar o gigante descer. (Igor, 9 anos e 3 meses, Desenho-Estória 1)

Eles arrumam a casa e com a galinha, eles nunca mais passaram fome... Ele fica feliz... (Igor, 9 anos e 3 meses, Desenho-Estória 1)

Eu tô indo no Mercado comprar coisas para eu fazer arroz... (Júlia, 7 anos e 9 meses, Desenho-Estória 1)

Ele tá correndo muito, é muito rápido... E tem uma corrida... E ele tem esse fogo, né, de tão rápido, então ele ganha a corrida... (José, 10 anos e 8 meses, Desenho-Estória 2)

\subsubsection{Projeção de situações de crescimento e conforto emocional}

Ele tá trabalhando na fazenda. Ele tá cuidando do gado. [E o que ele acha disso?] Legal. E tá pescando também. Ele gosta... (Pablo, 7 anos e 6 meses, Desenho-Estória 1)

Vamos dizer que as ovelhas gostam muito de comer capim e mato... Esse porquinho tá se divertindo na lama... O galo tá cantando... O cavalo deu uma volta, mas tá cansado e parou para comer o feno que seu dono colocou... (Gabriel, 10 anos, Desenho-Estória 1)

Ai todos ficam felizes para sempre... (Renata, 5 anos e 2 meses, Desenho-Estória 1)

Ai nasce o sol, o sol atinge a semente, a semente nasce uma plantinha e vai crescendo, crescendo... Quanto mais fazer isso, vira uma flor, ai vai nascendo frutos e a flor vai crescendo, crescendo até virar uma árvore... [E o que ela precisa para isso?] Regar, molhar, deixar no sol, ai ela vai crescer devagar... (Valentim, 7 anos e 1 mês, Desenho-Estória 5)

Eu fiz uma flor, que a menina fica muito feliz com ela... (...) E essa é a rosinha que vai crescer... (Júlia, 7 anos e 9 meses, Desenho-Estória 3)

7.2 Os encontros com as crianças e seus cuidadores familiares

Considerando o momento da saturação teórica, foi definida a realização de estudos de caso com quatro díades criança-cuidador, conforme indicado na Tabela 6. 
Tabela 6

Características clínicas das crianças selecionadas para os estudos de caso

\begin{tabular}{|c|c|c|c|c|c|c|c|}
\hline Criança $^{4}$ & Idade & Diagnóstico & $\begin{array}{l}\text { Caso } \\
\text { novo }\end{array}$ & $\begin{array}{l}\text { Tratamento } \\
\text { realizado }\end{array}$ & $\begin{array}{l}\text { Período } \\
\text { fora de } \\
\text { terapia }\end{array}$ & Recidiva & $\begin{array}{l}\text { Etapa de } \\
\text { tratamento }\end{array}$ \\
\hline Pablo & $7 \mathrm{a} 6 \mathrm{~m}$ & $\begin{array}{l}\text { Neuroblastoma } \\
\text { IV }\end{array}$ & $\operatorname{Jan} / 2009$ & $\begin{array}{l}\text { Cirurgia, } \\
\text { quimioterapia e } \\
\text { radioterapia }\end{array}$ & 11 meses & $\mathrm{Fev} / 2011$ & $\begin{array}{l}\text { Internação } \\
\text { após } 1^{\circ} \text { ciclo } \\
\text { de } \\
\text { quimioterapia }\end{array}$ \\
\hline Gabriel & $10 \mathrm{a} 0 \mathrm{~m}$ & $\begin{array}{l}\text { LLA Pré-B - } \\
\text { AR }\end{array}$ & Set/2008 & Quimioterapia & $\begin{array}{l}0 \text { meses } \\
\text { (fase de } \\
\text { manutenção) }\end{array}$ & Out/2010 & $\begin{array}{l}\text { Internação } \\
\text { após } 6^{\circ} \text { ciclo } \\
\text { de } \\
\text { quimioterapia }\end{array}$ \\
\hline Renata & $5 \mathrm{a} 2 \mathrm{~m}$ & $\begin{array}{l}\text { Neuroblastoma } \\
\text { IV }\end{array}$ & Out/2009 & $\begin{array}{l}\text { Quimioterapia, } \\
\text { cirurgia e } \\
\text { Transplante de } \\
\text { Medula Óssea } \\
\text { autólogo }\end{array}$ & 2 meses & Jun/2011 & Radioterapia \\
\hline Valentim & $7 \mathrm{a} 1 \mathrm{~m}$ & LLA & Mar/2011 & $\begin{array}{l}1^{\circ} \text { tratamento: } \\
\text { Quimioterapia } \\
1^{\mathrm{a}} \text { recidiva: } \\
\text { Cirurgia }\end{array}$ & $\begin{array}{l}1 \text { ano e } 7 \\
\text { meses }\end{array}$ & $\begin{array}{l}\text { Mar/2011 } \\
\left(2^{\mathrm{a}}\right. \\
\text { recidiva })\end{array}$ & $\begin{array}{l}\text { Internação } \\
\text { após } 1^{\circ} \text { ciclo } \\
\text { de } \\
\text { quimioterapia }\end{array}$ \\
\hline
\end{tabular}

\subsubsection{O encontro com Pablo e seus pais}

Pablo tinha 7 anos e 6 meses, no momento da coleta de dados. É o filho mais novo do casal (Paulo, 47 anos e Paula, 39 anos) e tem uma irmã (Patrícia, 12 anos), também fruto desta relação, provenientes da região Centro-Oeste brasileira.

Com o início do tratamento, a família mudou-se para Campinas, o que trouxe consequências para a rotina familiar. Paulo e Paula, ambos com Ensino Superior Completo e empregos fixos, interromperam suas atividades profissionais e contam com a renda de suas propriedades e apoio financeiro da família materna, em alguns momentos, para sustento familiar. O convívio familiar foi ampliado e ambos revezam os cuidados dos filhos, principalmente nos períodos de internação. Patrícia foi matriculada em um novo colégio, já Pablo interrompeu a frequência escolar devido ao início de tratamento e, novamente, com o diagnóstico da recidiva, realizando atividades enviadas pelas professoras, a distância.

Em janeiro de 2009, foi diagnosticado Neuroblastoma, estadio clínico IV, com metástases em medula óssea, ossos e linfonodos. Iniciou o tratamento pelo protocolo CCG 3891 que envolveu uma cirurgia para ressecção tumoral, quimioterapia e radioterapia

\footnotetext{
${ }^{4}$ Foram utilizados nomes fictícios para preservação da identidade das crianças.
} 
abdominal, com término da terapia em março de 2010. A realização do Transplante de Medula Óssea autólogo foi contraindicada por infecção fúngica. A recidiva foi evidenciada em fevereiro de 2011, em exames de acompanhamento, sendo reiniciado o tratamento quimioterápico no mesmo mês.

O primeiro encontro com a família aconteceu na enfermaria do hospital, em internação por neutropenia febril após o primeiro ciclo de quimioterapia de Pablo, por intermédio da psicóloga responsável pelo atendimento da família. Explica-se ao pai sobre a pesquisa, objetivos e procedimentos, ressaltando os cuidados éticos envolvidos. Nesse momento, Paulo explicou que optaram por não comunicar ao filho sobre a ocorrência da recidiva da doença e solicitou que tal informação não fosse abordada no contato com seu filho. Consente a participação no estudo e valoriza o espaço oferecido, enquanto possibilidade de ajuda nesse momento. Em seguida, com o pai e a psicóloga, foi realizado contato com Pablo para conhecê-lo. Paulo atuou como facilitador do contato e apresentação da proposta de estudo ao filho. Pablo é receptivo e comunicativo, mostrando-se familiarizado com a atividade gráfica e interessado pela tarefa.

Considerando o compartilhar dos cuidados parentais, o pai questiona sobre quem poderia participar da entrevista. Explica-se sobre o critério de cuidador-familiar e se reforça a possibilidade de escolha entre eles. Posteriormente, Paula informou que, em decisão conjunta, definiram que ela responderia à entrevista.

No momento da entrevista, é lido o Termo de Consentimento Livre e Esclarecido e a mãe faz uma pontuação quanto à frase "Estou ciente de que essas descobertas poderão ser utilizadas no futuro e que talvez meu filho(a) não se beneficie delas", sugerindo sua alteração, por conta do caráter terapêutico que percebia na intervenção. Explicam-se os motivos da frase e se agradece a confiança. Concorda em iniciar a entrevista, porém, recusou a gravação do áudio, justificando que ficaria mais à vontade sem o gravador. Permitiu as anotações no decorrer da entrevista e não se mostrou apreensiva no contato permeado pela escrita.

\subsubsection{A entrevista e suas categorias temáticas}

7.2.1.1.1 Repercussões psicológicas do diagnóstico oncológico

Ao abordar a questão do diagnóstico oncológico, a mãe expressou reações acerca da comunicação inicial e frustrações diante da temporalidade de tratamento. 
Ele teve o primeiro diagnóstico dia 13/01/2009... Foi horrivel! A gente nunca imaginou que o Pablo pudesse ter câncer... E a gente achou que tratava e ia embora! E a gente tá aqui até hoje...

Diante do senso de vulnerabilidade e ausência de controle que parecia vivenciar diante do adoecimento, Paula recuperou a história de vida infantil, destacando o planejamento e o desejo que permeavam a gestação, assim como eventos estressantes experimentados, parecendo buscar explicações para a ocorrência do câncer em seu filho.

Ai, o Pablo foi planejado até último dia da gravidez... A Patrícia já tava com 4 anos e eu queria ter outro filho, pra fazer companhia para ela... Eu sempre quis ter mais de um... Eu sabia o dia da ovulação e programei tudo para a fecundação. Ele foi muito bem-vindo e aguardado pela família toda... E é isso que me faz perguntar "Da onde um câncer?" Nunca imaginei que uma criança tão desejada fosse ter tanto problema... Já a Patrícia escapou... Não foi planejada, engravidei antes do que eu queria e correu tudo bem...

Então, na gravidez do Pablo eu bati o carro, quando tava com 2 meses... Eu chorei muito, fiquei com muito medo de perder o Pablo do tanto que eu chorava... (...) Mas o susto foi muito grande... Eu fiquei tensa com medo de perdê-lo. E ai, com 10 dias, ele fez xixi alaranjado. Imagina, né? O maior susto!

\subsection{Dificuldades advindas do tratamento}

O percurso de tratamento pareceu ser significado com intenso sofrimento, desgaste e privações à criança.

O tratamento judia demais, é muito desgastante, muito sofrimento... E o TMO [transplante de medula óssea] é muito arriscado para o Pablo, porque ele teve fungo, é complicado...

Mas ele sente a diferença, sente isso do "não pode"... Vou privar ele das outras comidas também? Eu tomo cuidado, mas acho que um pouquinho não vai fazer mal...

No relato, Paula demonstrou compreensão acerca dos cuidados necessários à saúde do filho, o que pareceu trazer sentimentos conflituosos em relação aos riscos envolvidos ao tratamento e seu desejo de controle da situação ameaçadora. Apegando-se à questão da alimentação, evidenciou um senso de potência, enquanto possibilidade de afeto e atenuação da perda experimentada.

\subsection{Experiências compartilhadas com outras crianças em tratamento}

A questão do relacionamento com outros pacientes e seus familiares, ao longo da convivência hospitalar, foi recorrente em sua fala. Valorizou o apoio mútuo percebido e a 
empatia estabelecida, apesar do alto custo emocional vivenciado em situações de piora clínica que parecem remetê-la à possibilidade da morte.

A gente conheceu outras crianças que faziam o tratamento junto com o Pablo, que começaram junto com ele, mas morreram... E é duro, porque a gente fica muito próximo aqui... Um sabe do que tá acontecendo com o outro, fica na torcida, mas sofre junto também...

E acho que a experiência com o Igor [paciente falecido há 2 semanas] influencia... Eu tento separar as experiências, mas é diferente, porque quando se fala de câncer tudo é possivvel...

Eu não tinha medo quando vinha para a consulta como amiga... O Paulo sim, se questionava se não ia acontecer com a gente [a recidiva, como com a outra criança], e eu dizia que ele era homem de pouca fé... Mas, no fim, minha fé que era tola...

7.2.1.1.4 Recidiva: ressignificações e a relação com a morte

O diagnóstico da recidiva oncológica pareceu ser vivenciado como uma ruptura das projeções maternas para a temporalidade da cura e reorganização familiar, parecendo remetêla à posição de um novo início do tratamento.

Ai, a hora que a gente acha que vai, que ia voltar pra casa e se reorganizar, vem outra cacetada. Você acha que a gente dá conta? Ele ficou 5 meses fora de terapia e agora a gente vai recomeçar...

Nesse momento, a incerteza diante do sucesso do tratamento ficou marcante, proporcionando sentimentos de desesperança e de impotência, ao refletir sobre as possibilidades do cuidar na posição de mãe.

Porque eu posso cuidar o tempo todo dai e fico perto... Vamos dar tudo para ele, fazer tudo, mas no fundo eu sei que não adianta...

Faço bem feita a minha parte, porque eu não quero ter culpa depois... Quero ter certeza de que fiz tudo que estava ao meu alcance e eu sei que estou fazendo...

A ameaça da perda mostrou-se intensa, vivenciada ora com temor, ora enquanto possibilidade de alívio do sofrimento que experimenta e para o qual se projeta em um futuro próximo. Cabe atentar para a emergência da reflexão sobre a morte enquanto escolha, o que faz pensar sobre o conflito onipotente experimentado, por vezes depositado na confiança para com a equipe de saúde.

Prefiro que ele morra do que tenha uma terceira vez... O tratamento judia demais, é muito desgastante, muito sofrimento... (...) É dificil lidar com isso, de que é melhor que morra, mas é a verdade...

Mas eu prefiro que ele morra do que ter que passar por isso outra vez... Não que eu queira, pelo contrário, mas eu sei da dificuldade de tratar... Não quero que ele sofra, que fique muito 
mal... É uma ameaça muito grande... Como vão fazer o TMO com o fungo, se antes não podia? Vão matar o guri! Não vão! Mas eu sei que eles sabem o que estão fazendo...

Diante da experiência antecipatória da temporalidade da perda, Paula refletiu sobre valores e formas de relacionar-se com seu filho e o processo de cuidar. Abordou a questão do tempo incerto e a valorização da vivência do atual, perpassando a necessidade de organizar-se para tal experiência.

No primeiro diagnóstico, eu protegia ele demais... Ninguém podia tocar no Pablo... Ele ficava no quarto dele e a gente evitava o toque ao máximo... Beijá-lo, então, de jeito nenhum, porque a médica orientou que podia contaminar... Ai agora, no segundo tratamento, eu tenho vontade de fazer tudo hoje, como se não fosse dar tempo se deixar pra depois...

Eu falo para o Paulo se preparar... A gente precisa estar preparado...

7.2.1.1.5 Comunicação com a criança sobre diagnóstico e tratamento

A temática da comunicação infantil surgiu já no contato inicial com a família e esteve presente também na entrevista. $\mathrm{O}$ velamento pareceu relacionar-se à experiência do primeiro tratamento, à compreensão da recidiva como frustrante e à desesperança frente ao tratamento, buscando omitir as informações enquanto tentativa de proteção e atenuação do sofrimento.

A gente não contou porque ela [irmã] não vai conseguir guardar segredo para o Pablo... A gente não quer contar, porque ele sofre por antecipação só por saber que é "quimioterapia" $e$ a gente acha que ele sofreria muito de saber que a doença voltou, "vou tratar para quê se não deu certo na primeira vez?"... A gente disse que ele tem uma pancreatite e que tem que tomar um remédio muito forte... E foi o que a gente disse pra ela também... Mas ela [irmã] é mais velha, não sei se vai acreditar... Mas enquanto não perguntar, a gente vai deixar assim... $\boldsymbol{E}^{\prime}$ melhor...

Para proteger meu filho... Ele já sofre muito, não precisa sofrer mais, à toa...

Foi interessante notar o movimento psicológico presente em seu discurso, inicialmente colocando o velamento como afirmativa, perpassando a situação da dúvida, buscando a opinião da pesquisadora e profissionais da equipe, finalizando com o contato com a percepção de suas próprias dificuldades em relação à aceitação da recidiva e ao desvelar ao filho, buscando uma maneira própria de enfrentar a situação conflituosa.

Ele vomitou, mas não sofreu nem um décimo do que sofria nas outras quimioterapias... Claro que é outro remédio, mas só de não ter o peso da "quimio" acho que já faz muita diferença... É o melhor mesmo, você não acha?

E não tem porque contar... O difícil é que o cabelo tá começando a cair e ele não é bobo...

A médica e a psicóloga falaram que ele já sabe que tem alguma coisa diferente acontecendo e que era melhor falar a verdade... 
Eu não conseguiria contar que a doença voltou... O Paulo também acha... É muito sofrimento desnecessário... Ele tá comendo, Marina... Quantas vezes fiquei insistindo para o Pablo comer nas épocas de quimio e nada... Ele não come a comida do hospital, mas come o que eu trago para ele... Pra mim, essa é a melhor resposta...

A gente achou melhor lidar com os problemas conforme eles aparecem, um de cada vez... É melhor...

7.2.1.1.6 Repercussões familiares: organização, relação conjugal e aspectos emocionais da irmã saudável

A família é compreendida por Paula como fonte de suporte, porém pareceu colocar atenção às repercussões psicológicas percebidas nas relações estabelecidas diante do adoecimento e do processo de tratamento do filho.

Desde isso de não trabalhar, ter que vir no hospital e se desdobrar, até a presença do Paulo mesmo... Antes ele saía 5 h30 para trabalhar e voltava às $20 \mathrm{~h}$... Agora a gente fica $24 \mathrm{~h}$ junto... Por um lado é bom, mas é estranho também... A convivência é maior, os atritos também...

Mas acho que depois que você vive com essa ameaça do câncer do seu filho, a gente muda a maneira de ver as coisas... Dá mais valor pras coisas mais simples, a gente vê tudo com outros olhos...

Apontou para dificuldades enfrentadas, no âmbito afetivo e financeiro, depositando expectativas de ganhos no manejo de tais questões, a partir do processo de aprendizagem da experiência anterior de tratamento.

O dinheiro pesa, mas o que mais pesa é o relacionamento, porque se um não apoiar o outro, não tem jeito... A gente não conseguiu na primeira vez, mas a gente sabe que desta vez tem que ser diferente se a gente quiser ficar junto... Eu falo "É isso que você quer?" Então vamos tentar... Hoje a gente tá dando muito mais apoio um para o outro... A gente reveza, cada um fica um pouco aqui...

Na primeira vez, eu e o Paulo nos distanciamos muito... A gente se conhece muito bem, no olhar, sabe? Não precisa falar nada... Mas saber do câncer do P abalou muito a gente... Diminuiu demais nossas relações sexuais, os momentos de namorar, do toque mais carinhoso... A gente não tinha tempo para isso... Nem disposição, muitas vezes... A gente buscou o padre, porque somos muito religiosos... E o padre disse que tinha que pegar na mão, sair um pouco de casa e de tudo isso, deixar as crianças com os avós ou em casa... Eu falava isso pro Paulo, que era dificil pra mim, mas ele não entendia... Precisou o padre falar pra gente ter nosso tempo e se aproximar...

Mas a parte sexual tá difícil... Ele tem que me entender como mãe... Não dá pra ter desejo vendo seu filho sofrer... E eu não consigo ficar longe do Pablo... Mas ele não aceita e vai para o quarto dele... De vez em quando o Pablo fala "Pai, a mãe precisa de uma massagem", risos, eu devo estar azeda! Risos 
Destacou, ainda, as implicações no compartilhamento de cuidados entre os filhos, o que pareceu colocá-la em contato com as reações da filha sadia diante dos cuidados com a saúde do irmão e das ausências dos pais.

É dificil dividir o tempo e os cuidados entre os dois... A Patrícia tem ciúmes, também quer a gente perto e acaba não tendo muito... Porque esse é um tratamento que exige muito cuidado, atenção redobrada, cuidados de limpeza, alimentação... Ela acaba ficando sem a gente... A gente tenta, mas não tem jeito... Aí, ela começou a ter dificuldade na escola, a professora falou que pode ser pra chamar atenção... Então tenho estudado mais com ela... Porque ela estuda, vai melhor e tem esse tempo só nós duas... Não sei se vai resolver, mas tô tentando...

Perceber as consequências sentidas por Patrícia na esfera escolar pareceu trazer vivências conflituosas à Paula, com sentimentos de culpa e questionamentos sobre seu senso de potência, principalmente pelo fato da mãe ter o magistério como atividade profissional.

\subsection{Estratégias de enfrentamento}

Ao longo da entrevista, destacaram-se várias estratégias de enfrentamento que pareceram auxiliar Paula no sentido de fortalecer-se para a lida. A preocupação com o seguimento das orientações médicas, desde o nascimento infantil, perpassando a situação do tratamento, pareceu proporcionar sentimento de potência e valorização do cuidar materno, mesmo diante do imponderável do tratamento.

Segui todas as orientações médicas à risca, tudo nos mínimos detalhes... Mas conseguimos controlar... Às custas de muita preocupação, sabe...

Investi muito na amamentação, porque sabia dos benefícios do leite materno... Ele mamava a cada 1 hora, até os 8 meses de idade... Só o peito! Eu sempre fiz tudo que diziam ser bom pro bebê...

No entanto, em alguns momentos, a percepção de privação experimentada pelo filho com os cuidados parece favorecer questionamentos quanto aos benefícios em situações com risco conhecido, apontando para aspectos afetivos presentes nas relações.

Dá um desespero ver seu filho sem comer o dia todo! Quando ele diz que tem vontade de alguma coisa, eu dou mesmo! Trouxe lanche do Mc Donalds esse final de semana... Eu sei que não pode, que tem risco, mas ele já não pode tanta coisa!

A fé revelou-se como importante fonte de apoio diante da ameaça percebida, atenuando o senso de impotência diante do tratamento. Foi interessante notar que ela pareceu reconhecer seu valor para dar conta do acompanhar do tratamento de Pablo, mesmo em face de situações em que se questionava sobre a adequação de suas crenças à realidade.

Eu penso "Meu Deus, ele teve fungo, mas ele tem o Senhor"... 
O Paulo sim, se questionava se não ia acontecer com a gente [a recidiva, como com a outra criança], e eu dizia que ele era homem de pouca fé... Mas, no fim, minha fé que era tola... [Tola?] É... Mas era importante para eu dar conta de vir e seguir o tratamento...

7.2.1.2 As sessões do procedimento de Desenhos-Estórias e temas emergentes

Antes de se iniciar a primeira aplicação do procedimento, Pablo mostrou as tarefas que o colégio havia enviado para ele fazer durante a hospitalização. Sinalizou sua percepção quanto à alopecia, demonstrando incômodo com a situação. Apesar de reconhecer com estranhamento a repetição dos efeitos colaterais, repetiu discurso familiar sobre o uso da medicação para o tratamento de pancreatite.

Olha meu travesseiro, tá cheio de cabelo! Esse remédio deve ser muito forte! [Forte, Pablo? Faz que sim com a cabeça e aponta o travesseiro] $E$ que eu tô com pancreatite, então preciso tomar remédio pra sarar...

\subsection{A fazenda}

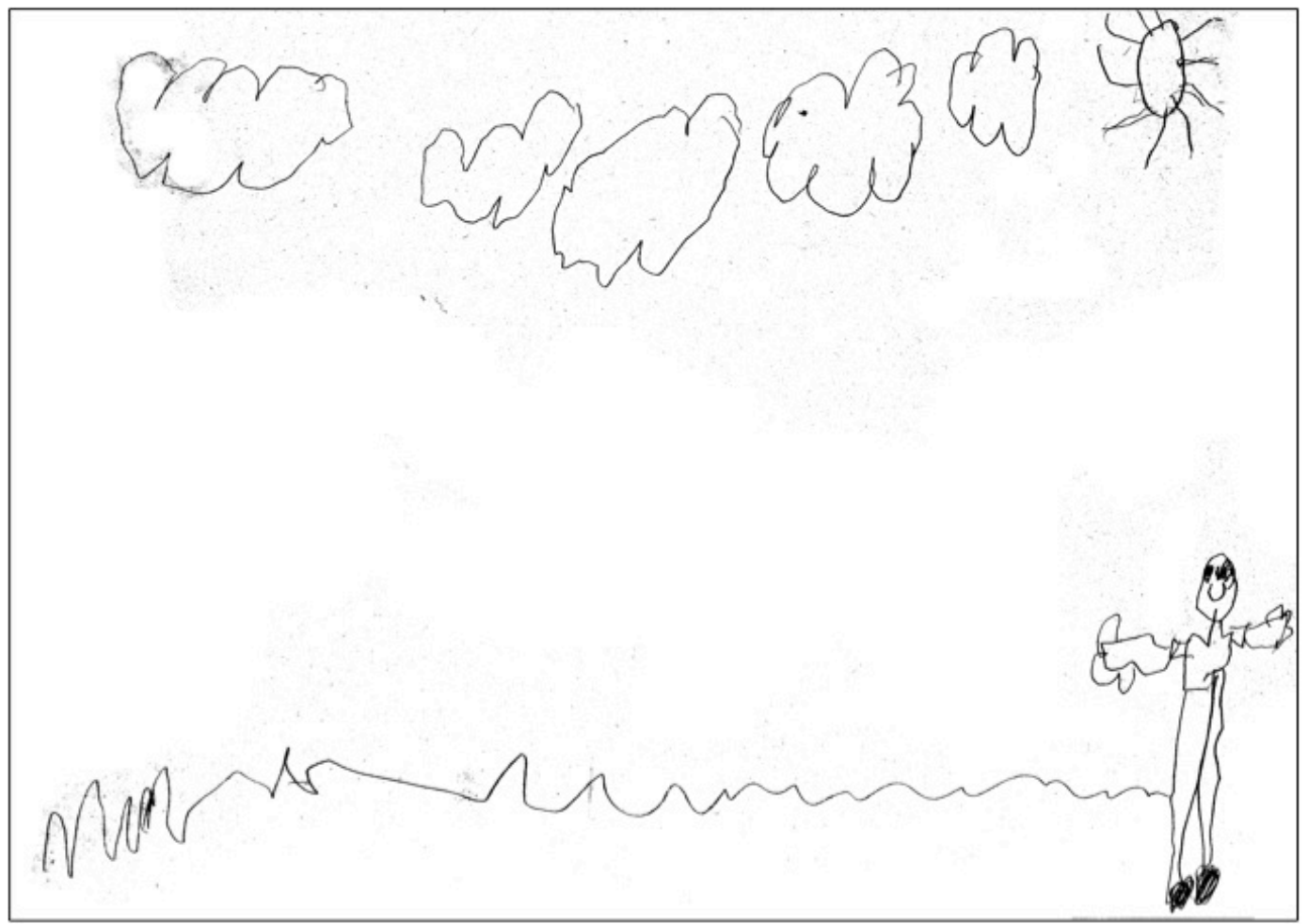

Quadro 1. A fazenda

Esse é meu avô [Seu avô?] Pai da minha mãe. Ele tá trabalhando na fazenda. Ele tá cuidando do gado. [E o que ele acha disso?] Legal. E tá pescando também. Ele gosta... [E como está o dia?] Legal, tem sol e ele tá morrendo de calor. [E quantos anos ele tem?] Nem sei, já tá de 
dentadura! É legal isso, ele morde a gente e nem deixa marca do dente, não tem, né? Risos [E como continua a história?] Já acabou.

Título: A fazenda

Na primeira unidade de produção, Pablo apresentou um desenho com adequação no tamanho e na disposição no papel, com traçado leve e poucos detalhes. Inicialmente, demonstrou alguma dificuldade no contar da estória, porém o contexto familiar pareceu favorecer o senso de segurança e o seu desenrolar. Evidenciou uma identificação positiva ao avô, com tendência de busca de proteção e afeto. Sugeriu certa dificuldade no contato direto com a realidade e própria situação de saúde, depositando no outro a fragilidade e a vivência de perdas, ao abordar questões relacionadas ao processo da morte e morrer.

A sessão foi interrompida por uma voluntária da instituição hospitalar que veio, a pedido de Pablo, raspar seu cabelo. Após o término do corte, porém, a criança demonstrou maior interesse em realizar as tarefas da escola. Permaneci ao seu lado por algum tempo, enquanto desenvolvia a atividade e combinamos novo encontro.

\subsection{A chuva}

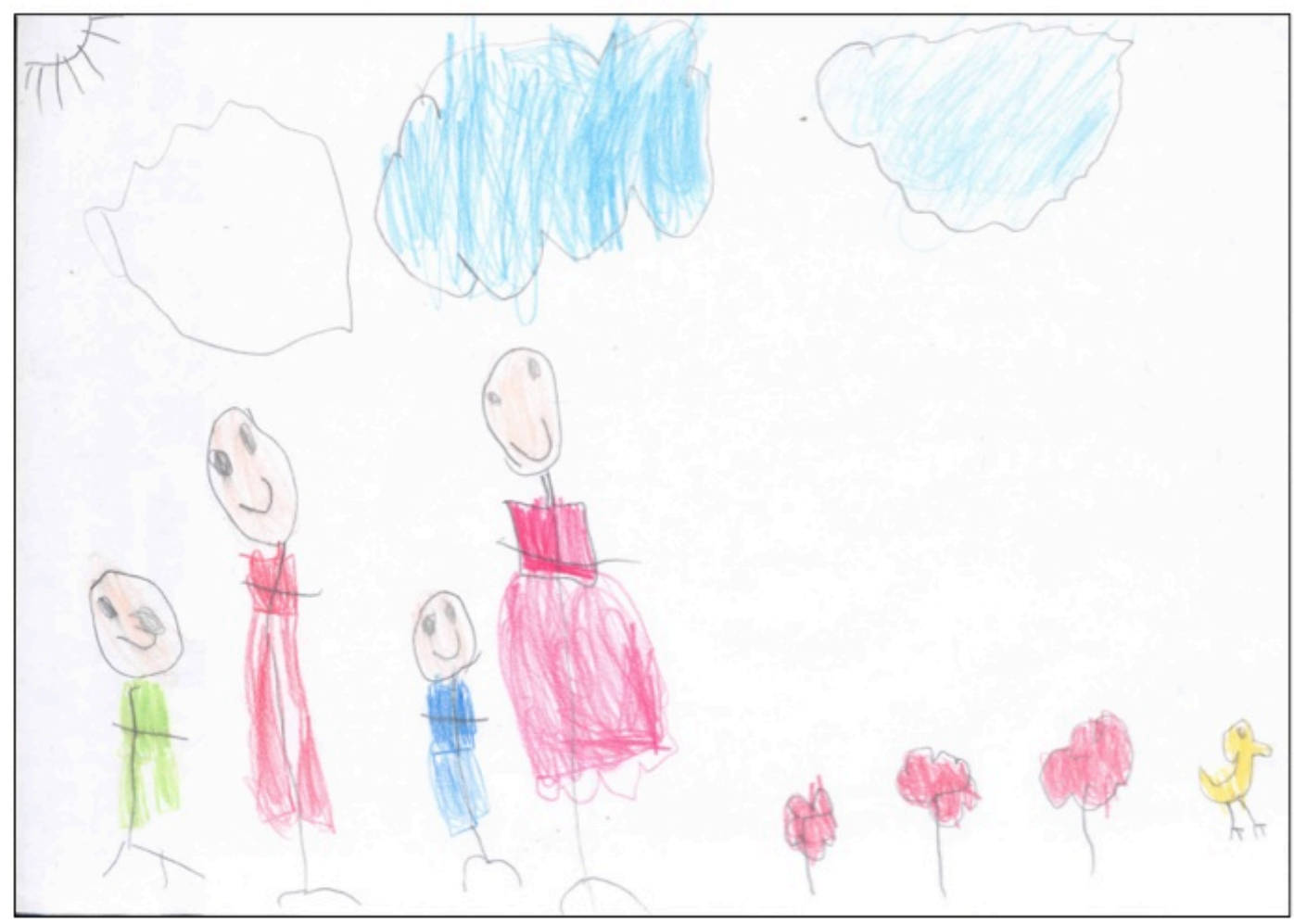

Quadro 2. Chuva 
Hoje eu vou desenhar de palitinho [Palitinho?] É... Assim ó... Essa é minha irmã, essa é minha mãe, sou eu e esse é meu pai. [E o que eles estão fazendo?] Não tão fazendo nada, nada, nada! [E sentindo?] Calor, tá um dia bem quente. Acabei desenhando um pato e essas são flores... Vou deixar uma branca (nuvem), se não eu canso muito de pintar... [E esse lugar?] É o jardim lá da minha casa... É gostoso brincar lá, é grande. Aqui tá todo mundo junto, a família inteira. Agora eu vou mudar! Essa [antes: pai] é a minha mãe! [Mudou...] É... risos É legal... [E a nuvem branca?] Tá sentindo que vai chover. [E o que acontece?] Todo mundo vai se esconder em casa, o pato vai também, ele não vai ficar aqui fora sozinho! [Pega os lápis de cor e constrói uma casa sobre o papel] Pronto! Deu certo! [Agora eles estão protegidos?] Agora sim.

Título: Chuva

No dia seguinte, enquanto o pai resolvia questões burocráticas referentes à alta hospitalar e à continuidade dos cuidados domiciliares, foi realizada uma nova sessão individual com a criança.

Na segunda unidade de produção, Pablo realizou um desenho de estrutura simples, apesar da riqueza das cores e de simbolismo. No entanto, deixou propositalmente alguns elementos em branco (sol e nuvem), com a justificativa de economia de energia, sugerindo sobre sua fragilidade e disponibilidade para a tarefa.

Representou a temática da família, caracterizando-na pela união e fragilidade de seus membros, contrapondo sentimentos de felicidade diante do familiar, à presença de sentimentos próprios da vivência do conflito, como a desproteção e o medo do abandono e da solidão. A confusão dos papéis na dinâmica familiar exprimiu sua percepção da desorganização familiar diante da ameaça, além de sugerir sobre a busca pela proximidade da mãe no momento da ameaça, inclusive enquanto possibilidade de abertura à mudança na realidade de ser doente.

Apresentou uma atitude básica de insegurança, demonstrando percepção da ameaça e evidenciando necessidades de proteção e abrigo, utilizando recursos concretos (objeto "lápis de cor”) nesse sentido, para além da representação gráfica e verbal. No entanto, tal proteção pareceu ilusória e temporária, rementendo à questão da vulnerabilidade da vida e do processo de adoecimento, marcado pela dúvida quanto à sua efetividade e projeção ao futuro. 


\subsubsection{Síntese compreensiva da díade}

O diagnóstico inicial de Pablo foi acompanhado por intensos sentimentos de vulnerabilidade e ausência de controle que pareceram potencializados pela notícia da recidiva. Apesar das dificuldades evidenciadas no processo de aceitação, a família pareceu se organizar para o período de tratamento e de enfrentamento dos aspectos emocionais envolvidos.

O contato com a realidade da fase de adoecimento e a compreensão sobre eventos pertinentes à temporalidade de tratamento, assim como as experiências compartilhadas com outros pacientes e familiares, pareceram favorecer a construção da compreensão sobre o mundo da recidiva oncológica e sobre si mesmos (Forghieri, 1993). A vivência de ameaça esteve presente no discurso da mãe e na expressão infantil, apesar do velamento da comunicação familiar, de forma semelhante aos achados de Hockenberry-Eaton et al. (1995). O não dito, verbalmente, pareceu trazer implicações para as vivências dos pais, preocupados com a preservação do segredo, e para Pablo, com déficits no contato com a realidade e em sua elaboração, com sentimentos de insegurança e desproteção. O contato com o real foi dificultado pelo adulto intermediário desta relação, enquanto justificativa de proteção à criança, mas principalmente como permissão de afastar o contato com suas próprias vivências, equilibrando o desejo de cura interrompido e o medo da morte, advindos com a notícia da recidiva.

A questão da morte surgiu com sentimentos de impotência, situando a criança na busca por proteção e amparo afetivo. Porém, em alguns momentos, Paula trouxe a compreensão desta concretização contraposta ao alívio pelo término do sofrimento que pareceu se reiniciar com a etapa atual de adoecimento, oscilando entre o desejo de exercer controle sobre a doença de seu filho e a vivência do luto antecipatório, em consonância aos estudos de Al-Gamal e Long (2010).

Considerando a situação de crise, mãe e criança abordaram sua percepção das relações entre o adoecimento e as repercussões na dinâmica familiar, ficando notória, no discurso materno, a preocupação com o desenvolvimento da irmã saudável e com a relação conjugal. A família pareceu em processo de elaboração inicial da comunicação da recidiva e em busca por se reoganizar para o enfrentamento do recomeço do tratamento e tomadas de decisão, como discutido no trabalho de Hinds et al. (1996), utilizando a proximidade afetiva e o fortalecimento da união como fontes de suporte e segurança para a adaptação à nova situação familiar. 
É interessante notar que, em um retorno ambulatorial subsequente, Paula buscou a pesquisadora com interesse na devolutiva da avaliação, preocupada com a questão da comunicação com o filho, dando sequência ao processo de reflexão e elaboração. Foram clarificadas as estratégias utilizadas pela família para se organizar e enfrentar o momento de crise e incerteza que vivenciavam. Em seguida, refletiu-se sobre a percepção infantil sobre os eventos relativos ao processo de adoecimento, desde os sintomas concretos que identificava como conhecidos, até no âmbito emocional, na vivência de ameaças e busca de proteção. A mãe resgatou suas inseguranças na comunicação com o filho, trazidas também no momento da entrevista, porém destacou as semelhanças com a avaliação de outros profissionais da equipe e a própria percepção sobre Pablo, o que pareceu favorecer o processo de reflexão sobre tal possibilidade. Ao final, foi reforçada a importância do seguimento psicológico à família naquele momento de tratamento e das possibilidades de auxílio nesta decisão e na estruturação da comunicação, considerando aspectos do desenvolvimento infantil e questões da organização familiar.

\subsubsection{O encontro com Gabriel e sua mãe}

Gabriel tinha 10 anos, no momento da coleta de dados. Mora com os pais (Gustavo, 32 anos e Giovana, 34 anos), irmão (Guilherme, 9 anos) e avô materno (Germano, 57 anos), em uma cidade a $30 \mathrm{Km}$ de Campinas. A mãe é dona de casa e dedica-se ao cuidado de saúde de Gabriel. O pai possui emprego fixo, com renda média de dois salários-mínimos, e o avô atua como profissional liberal, com renda variável, e também contribui para o sustento familiar. Guilherme cursa o Ensino Fundamental e apresenta repercussões emocionais com o adoecimento do irmão. Já Gabriel interrompeu a frequência escolar devido ao início do tratamento oncológico.

Gabriel foi diagnosticado com Leucemia Linfoide Aguda pré-B de alto risco, em setembro de 2008, quando iniciou o tratamento quimioterápico, pelo protocolo GBTLI LLA 99. Ainda na fase de manutenção de tratamento, em outubro de 2010, foi identificada recidiva isolada em medula óssea, classificada como muito precoce, e iniciado o novo tratamento quimioterápico, pelo protocolo ALL REZ BFM 2002. Após o terceiro ciclo de tratamento, a doença entrou em remissão.

A psicóloga de referência para seguimento da família mediou o primeiro contato com Gabriel e sua mãe, em internação por celulite no polegar direito, após completar o sexto ciclo de quimioterapia. Foram explanados os objetivos e procedimentos do estudo, perpassando 
pelas considerações éticas. Giovana mostrou-se receosa, porém concordou com a participação apegando-se à crença de, assim, contribuir com outras pessoas que enfrentam fase semelhante de tratamento. Gabriel foi bastante receptivo, afirmando adorar desenhar. Demonstrou preocupação com a veia puncionada no braço com dominância lateral, sendo acordado o início da coleta de dados pela entrevista com a mãe, e feita a realização das atividades com a criança após alternância do membro puncionado, a fim de minimizar interferências no grafismo.

7.2.2.1 A entrevista e suas categorias temáticas

No momento da entrevista, a mãe não permitiu gravação de áudio, justificando timidez ao gravador. Inicialmente, permaneceu atenta às anotações e, com o caminhar da entrevista, pareceu ficar mais à vontade.

7.2.2.1.1 Vivências emocionais no percurso diagnóstico e repercussões psicológicas do diagnóstico oncológico

$\mathrm{Na}$ entrevista, a mãe recuperou a história de vida infantil, permeada pelo processo saúde-doença.

Foi uma criança programada, a gente queria ter um filho e achou que era um bom momento... Mas ele deu trabalho desde que nasceu... Ele não pegava o peito de jeito nenhum! Parecia que ele tinha nojo, sabe? E isso me deixava muito triste... Além disso, ele teve refluxo desde pequenininho e também alergia ao leite de vaca... Foi superdifícil no começo, mas com uns 10 meses, tudo melhorou...

A suspeita de um novo adoecimento veio a partir de sintomas percebidos no filho. $\mathrm{O}$ diagnóstico, porém, perpassou diferentes hipóteses e tratamentos até culminar no câncer, o que pareceu trazer implicações para as vivências emocionais da mãe.

Ele sempre foi uma criança magra, mas sempre teve saúde... (...) Quando adoeceu, ele tava vomitando muito... Levei ele no postinho e disseram que ele tava com virose... Passou um mês e ele não melhorava... Teve febre e levei no hospital que eu trabalhava, disseram que ele tava com pneumonia e receitaram um monte de antibióticos, mas a febre não passou... Ele foi ficando pálido, a barriga inchou e essas glândulas do pescoço também... Pensaram que podia ser leptospirose e pediram uns exames para confirmar... Quando eu voltei pra buscar o exame percebi diferença no tratamento da equipe comigo, estavam mais carinhosos, cuidadosos, sabe? A médica chegou e disse que tinha uma alteração no exame e encaminhou pro Boldrini... Eu chorei até, porque fiquei muito assustada, eu já tinha ouvido falar do hospital e do que tratava aqui... Ela disse que era cedo pra falar alguma coisa, que ele precisava ser avaliado aqui no Boldrini primeiro... Na hora ela já chamou uma ambulância, que trouxe ele pro Boldrini, direto pra UTI! 
Nossa, foi muito difícil, eu não esperava que isso fosse acontecer... Nunca... Lá no hospital eu trabalhava na farmácia e fechava a conta de pacientes que faziam quimioterapia... Morria de dó de ver os pacientes, o sofrimento deles e das famílias... Nunca imaginava que ia passar por isso também...

Nas últimas falas, a mãe evidenciou também os significados atribuídos à instituição hospitalar e ao paciente oncológico, apegando-se a experiências anteriores à própria vivência diante do tratamento e do acompanhar seu filho, que pareceram influenciar sua maneira de se posicionar na situação, no momento inicial.

\subsection{Dificuldades advindas do tratamento}

No que se referiu ao tratamento, a mãe trouxe com maior ênfase as experiências de puncionar veia e realizar quimioterapias, com consequentes queda do sistema imunológico e hospitalização infantil, vivenciadas com nervosismo e tristeza.

O Gabriel ora todo dia antes de dormir, pede pra Deus ajudar para ele não perder a veia e não ter que ser furado de novo... Isso deixa ele muito nervoso, ele odeia e sofre muito!

Depois de fazer a quimioterapia, a defesa cai e sempre acontece alguma coisa: já teve boca em carne viva, dedo infeccionado, febre, e aí, tem que internar... Ele chora porque não quer ficar internado, é menino, né? Quer brincar com os amigos, ficar em casa... Eu tento falar dos beneficios de internar, do cuidado mais rápido e de perto, mas ele sempre tenta não internar...

Tento ajudar ele a não sofrer... Mas eu não gosto de hospital também... Quando eu tinha 8 anos, perdi minha mãe com câncer de útero e eu sempre visitava ela no hospital, quando tava internada... É dificil pra mim fica aqui... Mas tenho preparado meu psicológico para isso... Penso que duas vezes por mês, ele vai ficar internado e pronto... $O$ duro é quando tem intercorrência... A surpresa é ruim...

Notou-se a preocupação da mãe com as ressonâncias de sua forma de significar o contexto hospitalar na compreensão e enfrentamento do filho. Nesse sentido, Giovana buscou organizar-se para os períodos pré-programados de internação, porém as situações que rompiam o previsto revelavam a ausência de controle e pareceram trazer desconforto emocional.

7.2.2.1.3 Recidiva: frustração de expectativas e repercussões emocionais

A confirmação da recidiva oncológica surgiu para a família em meio a muitas expectativas com a aproximação do término do tratamento.

Ia terminar em dezembro o tratamento, mas em outubro voltou a doença... Foi outro baque, bem pior do que na primeira vez, porque a gente tava contando os dias para acabar com aquilo tudo! (...) Nossa, quando veio a notícia, ele ficou tão triste! Foi um período horrível... 
A gente tinha que esquecer da gente, para dar força para ele... Tentava esmagar meus sentimentos e todo o sofrimento para não passar para ele, mas quando eu não conseguia, saía de perto dele para chorar... Eu não gosto de fazer isso na frente dele...

Evidenciou a necessidade de entrar em contato com novos sentimentos seus, do filho e da família, buscando formas de lidar e de elaborar as emoções, com vistas à organização para o recomeço.

7.2.2.1.4 Comunicação com a criança sobre diagnóstico e tratamento

A comunicação inicial sobre o diagnóstico oncológico e, depois, sobre a recidiva, pareceu ocorrer de forma natural para a família.

A gente não esconde nada dele, sabe? Até tentamos, risos, mas não dá... Ele é um menino muito esperto...

A gente estranhou porque, em um retorno, a médica pediu um mielo para ter certeza do estado dele... E o Gabriel estava junto, ele sabia que se internasse era porque a doença tinha voltado...

A preocupação com a proteção de conteúdos difíceis pareceu ser vencida pelos recursos que percebiam em Gabriel para o enfrentamento e pela compreensão e participação ativa infantil em seu tratamento.

7.2.2.1.5 Repercussões familiares: organização e aspectos emocionais do irmão saudável

Ao abordar questões da relação familiar diante do adoecimento, a mãe evidenciou a percepção de ganhos na união e proximidade, principalmente em relação à família do esposo.

Acho que o adoecimento do Gabriel aproximou ela [sogra] da gente... Aliás, a família toda dele era distante... A minha não, sempre foram muito presentes e continuam assim... Eles choraram bastante quando souberam da recidiva e tentam nos apoiar de alguma forma, mas tá todo mundo abalado... Mas vai passar, a gente sabe que uma hora tudo acaba...

A percepção das repercussões emocionais nos familiares pareceu sensibilizá-la à compreensão dos limites individuais e valorização das tentativas de apoio por parte deles, aparentemente insuficiente para aliviar sua dor, apegando-se à esperança do fím do sofrimento vivenciado.

A mãe também apontou para as ressonâncias do tratamento de Gabriel para as vivências emocionais do filho mais novo. 
O Guilherme é dificil... Fica sempre sem a gente, sem o irmão, sem mim... tá terrível, desobediente, dando muito trabalho... Percebo que ele fica triste quando o Gabriel interna... É dificil... Tento ter mais paciência, mas não é fácil... Ele anda desobedecendo o tempo todo, respondão, sabe? Acha que a atenção é só para o Gabriel... Eu explico que o Gabriel precisa de cuidado agora, diferente dele, mas ele não gosta muito... Em casa, os jogos são só pra ele e ele briga comigo quando quero mediar a situação ou defender o Gabriel... Mas eu não vou fazer nada? Ele não pode jogar quando tá no hospital, né? Quero que ele aproveite o tempo em casa... Mas não sei se faço do jeito certo...

Apesar da percepção emocional de Gabriel, para além do concreto expresso em suas mudanças comportamentais, a mãe revelou a vivência do conflito entre o respeito ao filho saudável e ao desejo de suprir, no contexto domiciliar e familiar, as restrições experimentadas por Gabriel durante o tratamento.

\subsection{Estratégias de enfrentamento}

A fé se mostrou como principal recurso de enfrentamento da família, com significados de fortalecimento, fonte de sabedoria, conforto e esperança.

Só a fé mesmo ajudou a gente a superar esse momento e continuar firme...

Eu peço que Deus me dê forças e mostre o caminho...

Aí, nessas horas, ele gosta de cantar os hinos da igreja, deixam ele mais calmo... Ele não tá podendo ir à igreja por causa da imunidade dele, mas a gente sempre vai à igreja, ouvimos as palavras de força e passamos tudo para ele depois... Os irmãos e congregados oram sempre por ele e fazem visitas quando ele está melhor... Se a gente não tiver fé, se apegar a Deus, não tem apoio... A gente precisa ter alguma coisa para se apegar e Deus tá sempre presente nos momentos da nossa vida, principalmente nesses mais difíceis... Ele que nos dá força para seguir e acreditar que vai dar certo...

"Continuar" e "seguir" se revelaram como desafios importantes diante de todo o processo de adoecimento oncológico e tratamento infantil. Nesse sentido, para a família de Gabriel, a fé ocupou posição de destaque, auxiliando-os na manutenção da esperança e lida.

7.2.2.2 As sessões do procedimento de Desenhos-Estórias e temas emergentes

As duas sessões foram realizadas durante a internação de Gabriel. Habituada ao atendimento psicológico do filho, Giovana deixou-nos sozinhos espontaneamente, e a criança se mostrou bastante à vontade. 


\subsection{A fazenda de Carlos}

No primeiro encontro, inicialmente Gabriel expressou sua dificuldade em realizar o desenho livre:

Sem falar o que é pra desenhar fica muito mais difícil! Tem um monte de coisas que eu posso desenhar... Uhm... Vou pensar em uma coisa para fazer... Hospital não! Nada de hospital! Vou tentar fazer aquela coisa de fazenda, tipo chiqueiro, sabe? Nunca desenhei isso aqui...

Demonstrou preocupação com a escolha do tema, ponderando sobre a dificuldade da tarefa, suas habilidades e desempenho. Além disso, deixa clara sua recusa em desenhar o contexto hospitalar, sugerindo sobre as vivências emocionais naquele contexto. Conforme desenhava, descrevia os componentes e características, como se desse vida à produção, tecendo também a autocrítica sobre sua produção.

Fiz um lugar que fica o feno dos cavalos, como chama? Ah... É mais ou menos isso, uma casa para guardar feno... Vai ter cavalo e ovelha... Eles são os mais espaçosos... Todo mundo circulando! Risos... Quatro ovelhas, essa aqui vai ser conhecida como "A comilona", olha o tamanho dela, ela só come... Olha quanto espaço! Vou fazer uma casinha para os porquinhos se protegerem da chuva e vai ter lama, chiqueiro tem que ter lama! Beleza, um porquinho na área! Aqui vou fazer um galinheiro... Vixi, é a galinha ou avestruz? Risos Um galo... Chique, tem cabelo vermelho, risos... Cavalo vai ser difícil, tem pouco espaço... Esqueci o cabelo dele... Todo mundo sabe que cavalo tem cabelo... Esse cavalo tá mais pra filhotinho de cavalo, é... um filhotinho... E o feno... Vamos ver se falta alguma coisa... Falta sim! [Desenha frutas nas árvores] Pronto!

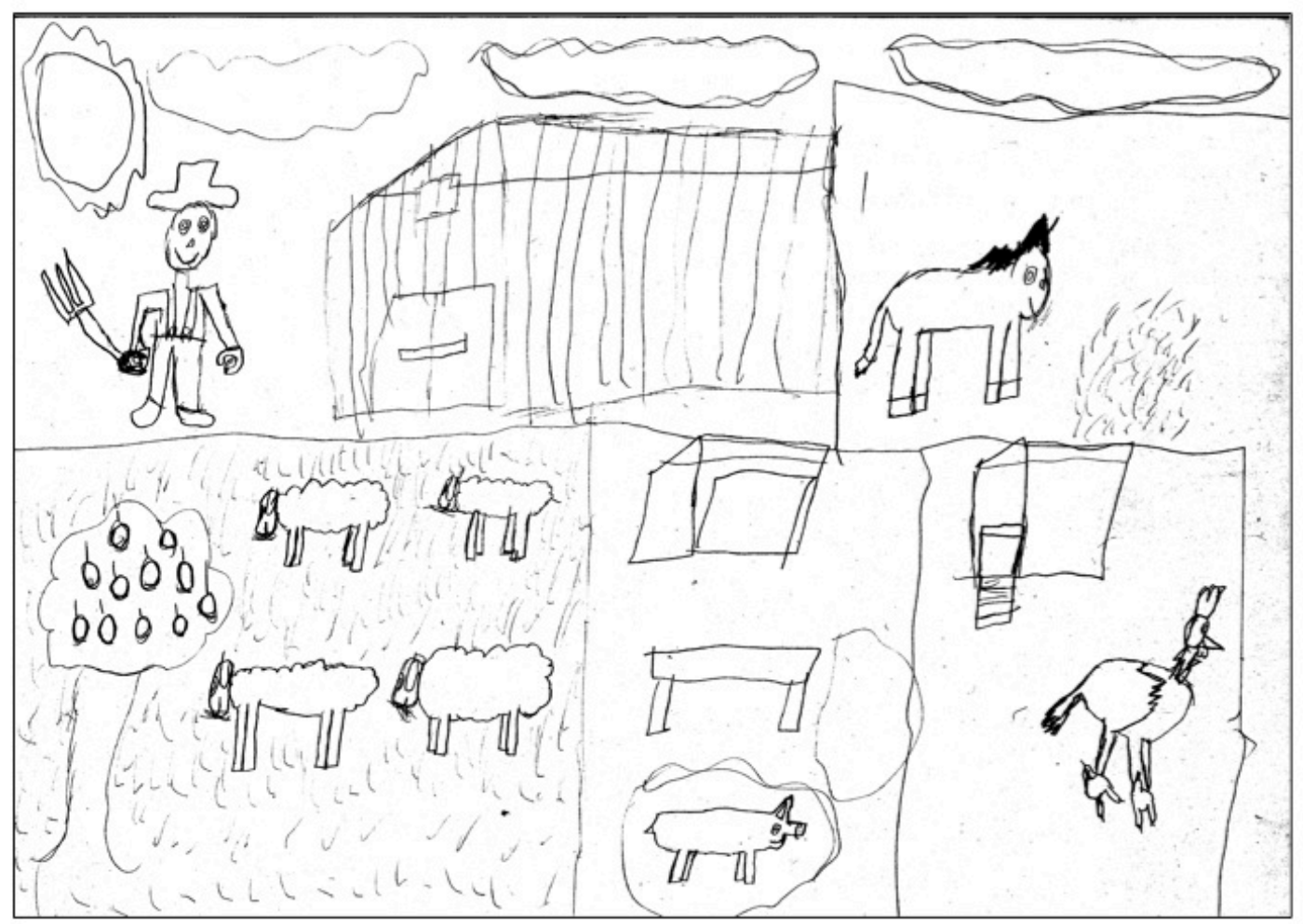

Quadro 3. A fazenda de Carlos 
Vamos dizer que as ovelhas gostam muito de comer capim e mato... Esse porquinho tá se divertindo na lama... O galo tá cantando... O cavalo deu uma volta, mas tá cansado e parou para comer o feno que seu dono colocou... Esse é o dono dessa fazenda toda, que cuida da galinha, da ovelha, do porquinho e do cavalo... Ele está olhando o lindo trabalho que acabou de fazer, a linda galinha, as quatro ovelhas, o porquinho e o lindo cavalo... [E como está o dia?] tá um sol de rachar! [E o que ele acha disso?] É bom, porque se chove, a lama vai aumentar muito e onde a galinha está vai alagar... É um solzinho bom, e só tem essas nuvens no céu... Tá um dia bom... [Você quer falar mais alguma coisa?] Eles são bichinhos felizes...

Titulo: A fazenda de Carlos.

O desenho de Gabriel apresentou traços fortes e riqueza de detalhes, com boa distribuição no papel. Destacou-se o desenho da árvore, repleta de frutos, porém sem raízes, sugerindo sobre a fragilidade e a questão da sustentação. Gabriel demonstrou satisfação e tranquilidade em relação ao contexto representado e clima tranquilo de "sua" natureza. Valorizou as demonstrações de cuidado do dono da fazenda em relação aos animais, em termos de afeto e alimento, e a proteção dos espaços separados de cada um deles, sugerindo o desejo de suprir tais necessidades, além de certo senso de isolamento e solidão. Tal desejo pode ser verificado, ainda, diante da percepção de ameaça, ao apresentar o conflito entre o bom e o mau, mediados pela intensidade dos fatos. A percepção do risco e da indefinição pareceu direcioná-lo à busca de proteção e afeto.

\subsection{O castelo de Sabrina}

Em sua segunda produção, Gabriel manteve o padrão comunicativo ao longo da atividade, pontuando sobre suas escolhas no processo de desenhar.

Vou fazer um lindo castelo! Vamos rabiscar! Essa não vai ter ponte levadiça não... Vou colocar uma barra de proteção, vai saber se um ladrão vai querer entrar, num castelo desses, né? Se desse para apagar, dava para fazer um castelo da Rapunzel, que todo mundo sabe que não tinha ponte, tinha que subir pela parede [Ofereço nova folha, mas nega] Mas dá pra fingir que aqui mora uma linda princesa... Aqui vou colocar chovendo, porque como a planta vai sobreviver sem chuva? Ela precisa de um pouco de sol e um pouco de chuva...

No momento que antecedia a elaboração da estória, pontuou sobre sua percepção do processo criativo, novamente questionando valores e potenciais.

Essa vai ser muito mais criativa... Quer dizer, eu achei que a da fazenda tá mais criativo, minha imaginação tá cansada... Deu pra fazer uma princesinha bem humilde... Não é aquela de artista, mas também eles são muito exagerados... Vou colocar uma bandeirinha aqui, mas tá bem melhor... 
Nessa produção, o castelo ocupou grande extensão da folha, sendo possível notar diferenças na proporção (como, por exemplo, as flores e as gotas da chuva) e locais com reforço do traçado, sugerindo sobre o valor atribuído aos elementos em sua vivência e aspectos do conflito em questão. Demonstrou identificação com o sexo oposto, relacionando a vivência da protagonista com sua própria internação, destacando sentimentos de restrição e aprisionamento, apesar da valorização da proteção percebida. A vivência de sentimentos conflituosos também se verificou em relação ao elemento chuva (permite crescimento da planta, porém impede saída da princesa) e à permanência no local (gosta de ficar no castelo, porém sente-se triste e torturada), possivelmente relacionados aos sentimentos experimentados nesta relação na situação de incerteza do adoecimento e tentativa de integração do bem e do mal, pertinentes à situação de tratamento.

Gabriel explicitou a percepção de ameaça e sentimentos de desproteção, reforçando sua necessidade de proteção e provisão de segurança, sugerindo sobre sua fragilidade e apreensão diante da morte e solidão. A percepção de ameaça, novamente, se revelou em relação à intensidade, sendo o excesso significado como perigoso, enquanto sua ocorrência em menor escala, benéfica. Abordou, ainda, aspectos da autoimagem, capacidade e menos-valia, colocando a beleza exterior como passageira, ao passo que a interior permaneceria, o que fez pensar sobre o movimento em busca ao amor por si próprio e pela vitalidade.

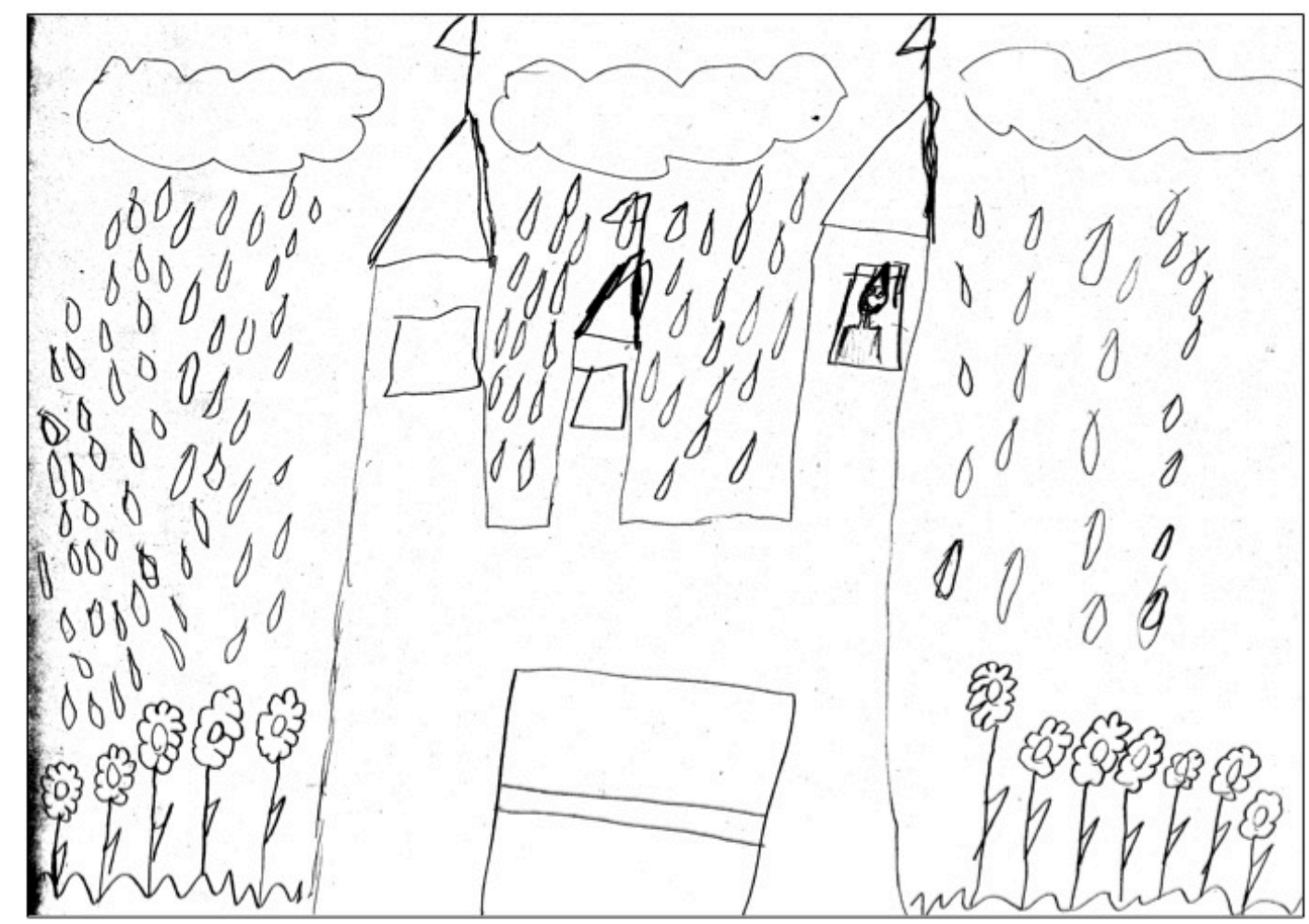

Quadro 4. O castelo de Sabrina 
Aqui morava uma linda princesa, que o pai não deixa sair de casa, mas também não é hora de sair... Tá chovendo muito e ela iria molhar o vestido, né? Mas nem eu saio daqui, fíco só nesse quarto de hospital, sem videogame... Continuando... Ela não saía por nada, ela gostava de ficar no castelo, tinha lindas flores uma de cada cor da natureza... [E como ela se sente?] Triste, é uma tortura! [E quem mora nessa casa?] Ela, o pai e a mãe [E como é o castelo?] Muito lindo! Quando não é muito bonito por fora, é muito bonito por dentro, grande, grande... [Você quer falar mais alguma coisa?] Acho que não...

Título: O castelo de Sabrina.

\subsection{O cowboy Woody}

No dia combinado para o segundo encontro, encontrei Gabriel e sua mãe jogando no leito. Prontamente interromperam a atividade lúdica e permitiram minha entrada, e Gabriel aceitou realizar nova sessão de D-E.

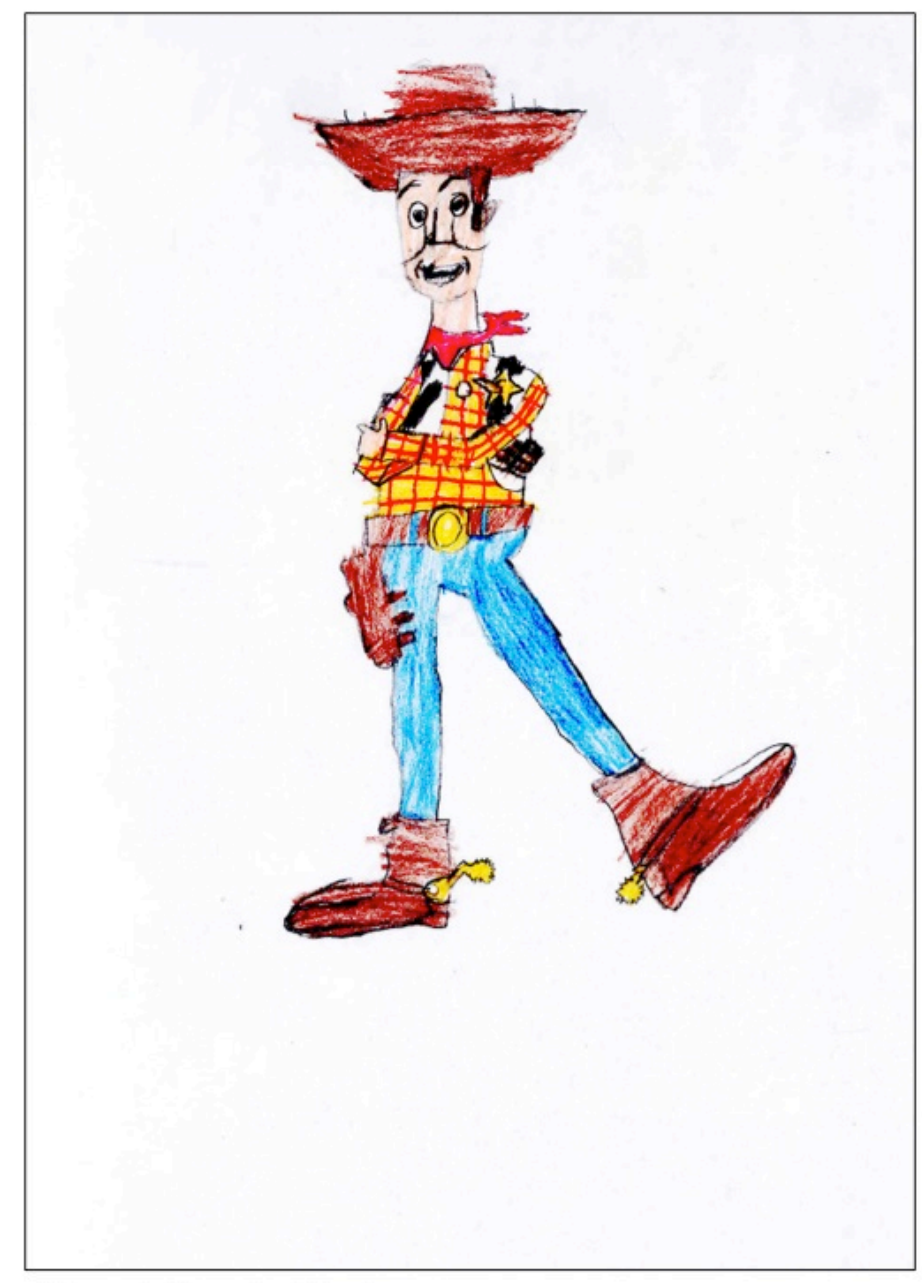

Figura 5. O cowboy Woody 
Ele é só o personagem... Se você quer saber da vida desse cowboy, ele é Woody Irrá. Ele só tá fazendo pose para ser fotografado, mas foi desenhado em vez de fotografado... [E o que ele achou?] Pelo visto, muito bom! Porque ele tá todo sorridente! [E o que ele está sentindo?] Pensando em como tá o desenho, preocupado... [E qual seria a idade dele?] Ele é um boneco! [Mas se fosse uma pessoa, quantos anos teria?] Uns 20 anos, eu acho... [E o que ele tá fazendo?] Ele vai ficar ao lado do seu parceiro e melhor amigo... Do Rex, Buss, Porquinho, soldadinho, Lemy, Slink e da sua namorada Jetty. Ele gosta de ficar com os amigos, brincar com seu dono... [E do que ele mais precisa?] Precisa dos amigos, de atenção e nunca ficar solitário. [Solitário?] É... Ele não gosta de ficar sozinho... Com os amigos fica bem melhor... [Você quer falar mais alguma coisa?] Não...

Título: O cowboy Woody

Após a distribuição dos materiais, solicitou que eu pegasse a revista do Toy Store que possuía no quarto e informou que desenharia o cowboy Woody.

Vou fazer isso pra dar a sensação de que ele tá gordinho, risos, eu nunca tinha feito isso, isso é novo... Depois eu posso pintar? Vai ficar bem legal se eu pintar... [Você pode fazer como preferir]

O personagem ocupou a região central da folha, com riqueza de detalhes e adequação das cores. No que se referiu ao relacionamento com pares, manteve certa ambivalência afetiva, expressando sentimentos de alegria e afeto, em oposição ao receio da solidão e desproteção. Valorizou o potencial desses outros significativos, na oferta de segurança e proteção, que podem abranger amigos, familiares e mesmo a equipe, de forma a amenizar a solidão no tratamento, na internação e no adoecimento. Interessante notar que o desenho expressou senso de potência, no entanto, representado em um boneco. Na vida real, diante da vivência ameaçadora e da angústia de separação, as trocas afetivas com o outro pareceram favorecer seu fortalecimento psíquico.

\subsubsection{Síntese compreensiva da díade}

O processo diagnóstico de Gabriel mostrou-se permeado por dificuldades em sua definição, trazendo implicações para o atraso do início do tratamento, seus fatores prognósticos (Ministério da Saúde, 2008), bem como um importante desgaste emocional.

A comunicação da recidiva foi acompanhada por sentimentos de frustração diante da expectativa do término da terapia e da necessidade de organização para o recomeço do 
tratamento, sendo a participação da criança ativa em todo o processo de cuidado. Cabe ressaltar a valorização familiar dos recursos de enfrentamento da criança nesse sentido, o que pareceu favorecer a comunicação aberta, assim como a apropriação infantil das informações e dos cuidados do tratamento. Em sua produção, a criança explicitou a ameaça percebida em relação ao mundo e sua busca por proteção e segurança, porém, reafirmando a percepção familiar, evidenciou recursos para elaboração das vivências que pareceram auxiliá-lo nessa etapa do tratamento.

Em relação às dificuldades da temporalidade do tratamento, destacaram-se as vivências de internação hospitalar, de forma semelhande ao estudo de Bruce et al. (2011). Para Giovana, remetendo-a a vivências anteriores com situações de adoecimento e perda, atenta às ressonâncias de sua significação do período para o enfrentamento de seu filho. Para Gabriel, tal vivência pareceu trazer importante restrição, com sentimentos de tristeza diante das perdas e das ameaças percebidas. Com intuito de atenuar tais sentimentos, a mãe revelou tentativas compensatórias em contexto domiciliar, que ao mesmo tempo em que contribuíram para seu senso de cuidado no papel materno, geraram reflexões sobre as implicações para as vivências do filho saudável. Os sentimentos conflituosos foram abordados pela mãe e pela criança, evidenciando a dificuldade em integrar tais vivências e estabelecer uma harmonia. No entanto, buscaram se organizar para enfrentar as surpresas e emoções pertinentes ao período de tratamento, apegando-se à busca de controle, à fé e ao apoio familiar e social neste sentido.

A devolutiva foi realizada com a mãe, ainda no período de internação de Gabriel. Inicialmente, foi abordada a percepção das estratégias utilizadas pela díade para lidar com o diagnóstico da recaída e as dificuldades pertinentes ao tratamento, reconhecidas pela mãe, com certa timidez. Demonstrou preocupação com as vivências do filho diante desta fase de tratamento, sendo pontuada a percepção de ameaça em relação ao mundo e a evidência de recursos de enfrentamento, conforme percepção materna já declarada. Antes do encerramento, foram reforçados os benefícios do acompanhamento psicológico para fortalecimento interno e enfrentamento do período.

\subsubsection{O encontro com Renata e seu pai}

Renata tinha 5 anos e 2 meses, no momento da coleta de dados. Os pais (Ricardo, 32 anos e Rita, 29 anos) não tiveram relacionamento duradouro, e a criança, desde o nascimento, vivia no interior da região Norte do país com a avó paterna (Rosa, 52 anos) e seu companheiro (Rene, 70 anos), aposentado, com renda de dois salários-mínimos. Possui uma 
irmã (Roberta, 3 anos), fruto do relacionamento atual do pai e irmãos por parte de mãe, os quais o pai não soube precisar quantos e suas idades, devido ao contato familiar restrito. Diante do diagnóstico e encaminhamento para tratamento nesta instituição, Renata ficou sob os cuidados de Ricardo, em casa de apoio vinculada ao contexto de tratamento, na cidade de Campinas. Atualmente, ele está desempregado, contando com auxílio financeiro da família e amigos. A rede social de apoio construída no período de tratamento também se mostra importante fonte de suporte para adaptação inicial e enfrentamento do processo de tratamento.

Em outubro de 2009, foi diagnosticado Neuroblastoma, estadio clínico IV, com metástase em medula óssea e em múltiplos ossos. Realizou tratamento pelo protocolo CCG 3891, com quimioterapia, cirurgia para ressecção tumoral e Transplante de Medula Óssea autólogo, com término da terapia em abril de 2011. A recidiva foi identificada em junho de 2011, sendo interrogada a possibilidade de tratamento quimioterápico e iniciada radioterapia, em região abdominal e em membro inferior.

O contato com o pai foi realizado por intermédio da psicóloga de referência para o atendimento, no setor de Radioterapia. Apresentaram-se a pesquisa, seus objetivos, procedimentos e cuidados éticos. Ricardo teceu comentários sobre o comportamento da filha e dificuldades enfrentadas na educação da menina, considerando benefícios do contato nesse momento. Auxiliou no contato com Renata, que se mostrou receptiva e comunicativa. Concordou em conhecer a sala da psicologia no setor de Radiologia, local combinado para a aplicação dos procedimentos de coleta de dados. Demonstrou interesse por outras atividades disponíveis na sala, porém envolveu-se na proposta gráfica, comunicativa e criativa.

\subsubsection{A entrevista e suas categorias temáticas}

7.2.3.1.1 Vivências emocionais no percurso diagnóstico e repercussões psicológicas do diagnóstico oncológico

A percepção dos sinais do adoecimento se iniciou em sua concretude, nas atividades diárias em que a criança se empenhava.

Mas ai com três anos quando ia subir a ladeira ela começou a sentir fraqueza nas pernas... E com uns três anos e meio começou a sentir dores, a não comer... Ai que eu levei ela no médico pra ver o que tava acontecendo e começou a tratar infecção de urina, anemia...

O período entre a percepção inicial dos sintomas e o diagnóstico foi permeado por tratamentos para outras patologias, exames e a percepção de piora clínica. 
E eu já tinha comprado um monte de antibiótico pra ela e nada, assim, de ficar boa... Aí quando foi um dia, eu pedi pra ele internar, porque já tava avançando, né, pedi pra ele internar... Ele falou que internava, mas que não era pra gente tirar, né, pra nós deixar ela um tempo lá... Ai eu fui trabalhar e quando eu voltei pra visitar no outro dia ela já não estava mais lá, tava num outro hospital, que é uma fundação hospitalar, que é tipo o Boldrini, né? Ai eu cheguei lá e perguntei e ele disse "Não, ela foi pra outro hospital", dai eu falei "mas tinha deixado internada aqui"... Ai ele mandou chamar a Dra., que era daqui do Boldrini também, ela falou que a Renata tava lá... Ela mandou bater um Raio X e depois eles mandaram eu fazer um monte de exames... Esses exames foi até pago... Mas tinha que fazer...

Apesar do contexto sociocultural e da fragilidade da relação pai e filha até o período, Ricardo mostrou participação em momentos cruciais, oferecendo possibilidade de diagnóstico e tratamento à criança.

Eles levaram ela lá pra fundação e quando foi 10 dias, minha mãe falou que eles queriam conversar comigo e com a mãe da Renata (...) Aí, estranhei, né? Querer falar com os dois...

Ai quando a Dra. descobriu já mandou vir direto para cá... Foi isso que ela falou na conversa, da doença de vir pra cá pra Campinas, do tratamento... Ela falou que era quase igual, mas que lá não tinha lugar pra fazer a cirurgia e que era bom ela vir pra Campinas passar uns 3 meses e voltava...

A sugestão da gravidade pela solicitação de presença dos pais trouxe à tona a questão do relacionamento entre eles, exigindo uma reorganização para a oferta dos cuidados em saúde e afetivos a Renata.

Até, inclusive, quando a Renata veio pra cá, eu tava trabalhando e pedi pra minha mãe perguntar se ela não podia vir. Aí a irmã dela disse que ela não poderia vir porque ela não sabia de nada, né, é burra, mas falei que isso não era problema não, porque a pessoa aprende... $O$ que que a pessoa não aprende? A pessoa aprende a estudar, aprende outras coisas, eu também não sabia de nada não, aqui que eu tô aprendendo... A pessoa aprende, $o$ mundo ensina...

Assim... A mãe dela não quis vir, né, a minha mãe é senhora já e não podia vir, até porque ela tem nervoso, né? E minha mãe não ia aguentar, porque não é todo mundo que aguenta... Inclusive, acho que nem a mãe da Renata ia aguentar... A médica até falou que normalmente quem vai é a mãe, mas eu disse que não é o caso da Renata.

Ao mesmo tempo em que evidenciou a fragilidade do vínculo com a mãe, utilizando outras pessoas na mediação da comunicação e demonstrando pouco apreço a sua postura diante da filha, Ricardo pareceu valorizar suas capacidades de aprendizagem e superação dos desafios do tratamento, na condição de cuidador principal. 


\subsection{Dificuldades advindas do tratamento}

O período de tratamento de Renata foi descrito pelo pai como um período de "batalha", marcado por momentos tranquilos e outros de ameaça.

Desde 2009 que nós tamo aqui, eu mais a Renata... Na batalha, né? A Renata já passou por poucas e boas já...

... o tratamento da Renata foi bom, mas teve uma vez que ela pegou uma infecção e ficou 40 dias internada, inclusive na UTI... Então, teve tempos tranquilos, mas teve vez de eu achar que não ia levar a Renata pra casa... Porque de cada 8, só um escapa dessa infecção que ela teve.... A hospitalar, sabe? Até a médica falou "Pai, eu pensei que o Sr. ia sem a Renata... Foi grave, gravissimo"...

A compreensão da gravidade de algumas situações clínicas de Renata foi mediada pela equipe, na comunicação realizada e nas condutas tomadas que pareciam auxiliar o pai na apropriação sobre questões do cuidar, ao mesmo tempo em que se abriam possibilidades da morte.

Outra dificuldade enfrentada foi a questão do ser-pai, na posição de acompanhante no tratamento, com exigências de apropriação acerca do tratamento e, também, do cuidado domiciliar infantil, atribuído, socialmente e na realidade infantil, à figura feminina.

Algumas coisas eu já sabia, mas aprendi mais... Assim, tive dificuldades nisso de dar banho... O pai é sempre mais complicado dar banho... Eu não dou banho... Você sabe como é... Ainda mais agora, que tá tendo um monte de notícia de pai fazendo besteira com filho... A gente fica mais preocupado das pessoas falarem... Besteira, bobagem... Porque a gente tá no tratamento, mas não é a mãe, né? A gente preocupa das pessoas falarem... (...) Eu nem ligo, sabe, mas falo pra ela que tem que ser independente, que tem que aprender as coisas pra caso a gente fique longe... É bom pra ela também, né? E ela aprende, é esperta...

Nesse sentido, Ricardo valorizou o processo de aprendizagem no qual se encontrava, buscando estratégias dentro de seus conhecimentos para favorecer a independência infantil e, assim, minimizar possíveis desconfortos por ser pai em um lugar tipicamente feminino.

\subsection{Recidiva: do impacto à incerteza}

Ao abordar a comunicação da recidiva, o pai recuperou situações em que a suspeita fora descartada. Expressou sua tristeza diante da confirmação e depositou esperança nas possibilidades de tratamento para o enfrentamento da situação de ameaça.

Já levei uns 3 sustos já sobre essa doença já... Porque há uns 8 meses atrás achavam que a doença tinha voltado, ai foram fazer exame e viram que era só um alarme... E agora de novo... Daquela vez era alarme falso, mas agora deu nas perninhas, né? Mas isso não quer dizer... Quem é que sabe o que vai acontecer... 
Ainda que a Dra. me deixou um pouco triste porque ela falou que a Renata ia fazer só quatro rádio e ia voltar pra casa... Isso me deixou um pouco triste, porque fiquei pensando que não tinha mais jeito... (...) Mas ai eu cheguei aqui, tomei coragem e perguntei quantas rádio ia fazer, esperava que ela me respondesse a mesma coisa, só quatro rádio, mas não ela me disse "Pai, na soma, vão ser 37 rádio que ela vai fazer", que vai ser na perninha, que é onde tem um restinho, e no abdome, que tem também... Ai deu mais esperança de lutar... Que a rádio vai ajudar bastante e tô pensando que no próximo exame não vai dar mais nada...

Foi uma conversa nada agradável, né? Mas não tem outro jeito... Primeiro a gente fica triste, tem que ficar mesmo... Fiquei uns três, quatro dias triste... Mas depois não adianta, né? Igual lá em Rio Branco, fiquei triste, mas depois fiquei alegre de pensar que ia tratar... E aqui a gente fica mais triste porque tá só eu e ela, né? Sozinho, sem saber o que vai acontecer...

A incerteza sobre o futuro parece imperar em suas vivências diante da notícia da recidiva, principalmente na situação atual de tratamento da filha, em que pareceu depositar na continuidade das realizações da radioterapia a esperança de obter resposta clínica curativa, em meio à compreensão das restrições de possibilidades terapêuticas. Evidenciou, ainda, sentimento de desamparo por estar só e distante da cidade de origem, fontes de apoio e suporte diante das adversidades.

7.2.3.1.4 Comunicação com a criança sobre diagnóstico e tratamento

A questão da comunicação infantil sobre a recidiva oncológica foi tratada com naturalidade pelo pai, apesar de se questionar sobre a compreensão da filha, apoiando-se na comunicação médica e buscando favorecer a colaboração de Renata, ao colocar o tratamento como condicional para a realização dos desejos familiares de retorno à vivência domiciliar.

A médica explicou que voltou... Não sei se ela entende direito, mas falo que tem que fazer a rádio pra poder ir pra casa e ela colabora muito...

A comunicação com a família, mesmo que distante, também se mostrou importante.

Conto pro pai, digo "Oh, pai, a doença tá aí ainda”... Igual dessa última vez, falei "Oh, pai, eu tô indo embora, aqui não tem mais tratamento pra Renata" Ele pergunta, como assim, se aqui não era melhor, mas eu falo que já fizeram tudo e que eles acham que o melhor é fazer o tratamento lá mesmo, que ela vai fazer essas rádio e vamos voltar... (...) Ah, é dificil, né, fica um pouco triste, mas ai ele falou que ia ser bom pra nós, que a gente teria apoio da família, que aqui a gente não tá tendo... Apoio da família, dos amigos... Não tem nada melhor que isso, né?

No contato telefônico com o pai, pareceu compartilhar expectativas frustradas com relação ao tratamento e validar sentimentos experimentados, de forma a fortalecer a esperança depositada no apoio familiar. 
7.2.3.1.5 Repercussões familiares: organização e relação conjugal

Ao abordar as repercussões nas relações familiares, Ricardo expressou suas preocupações em relação ao distanciamento da esposa, filha e círculo social em virtude de acompanhar o tratamento de Renata.

Foi difícil né? Você imagina, largar mulher, filha, trabalho, amigos, tudo lá no Acre e vir? Mas eu deixei bem claro pra ela "Olha, eu tô indo, mas pra cuidar da outra filha" e o importante é que ela tá bem e a outra também, ficou com a mãe...

A gente aprende viu... E ela me apoia de tá aqui, ela que me deu força de vir pra cá... Se fosse outra, não tava nem aí, mas ela graças a Deus entende e me dá força... E quando eu fui pra lá a última vez, que eu passei de 10 a 15 dias, as pessoas não falaram mal dela não... Falaram que ela não saía de casa...

Buscou clarificar os objetivos de sua viagem, evidenciando o receio com más interpretações de sua ausência e margens à infidelidade conjugal. Perceber o apoio da companheira e lealdade pareceu fortalecê-lo no retorno ao acompanhamento da filha e persistência nesta posição.

\subsection{Estratégias de enfrentamento}

Para o pai, estar distante da cidade de origem e da família foram situações desafiadoras ao longo do tratamento. Nesse sentido, Ricardo destacou o valor das amizades estabelecidas no convívio hospitalar.

Não foi fácil não... O primeiro mês, segundo mês, terceiro mês foi muito difícil... Mas aí a pessoa vai fazendo amigos e vai dando um jeito de levar...

Apegou-se também a Deus, enquanto companhia e apoio diante dos momentos de solidão e desamparo.

Graças a Deus, Deus nunca abandonou a gente... Por mais que a gente esteja só, a gente nunca tá sozinho, Ele sempre tá com a gente, tem que ter fé... Mesmo a gente não sendo nenhum santinho, né, porque eu não sou... Peço a Deus pra dar força pra gente, saúde pra ela, não só pra nós dois, mas pra todas as crianças que eu vejo...

Atribuiu à fé significados de fonte de fortalecimento e de restituição de saúde, apegando-se à permanência da vida, enquanto sinal do desejo de Deus, como instilar de esperança.

Eu digo, se Deus não quisesse que a Renata ficasse comigo, tinha levado ela naquela época, né? E ela tá aí, firme e forte... 
Enquanto a fé parece fortalecer o pai em sua lida, é ele quem demonstra buscar auxiliar Renata nos momentos de dificuldades enfrentados no tratamento.

Eu não vejo a minha filha doente... Claro que às vezes ela fica mais amuada, dá uma angústia, depois de exames, da rádio, mas eu digo a ela "Que que é isso? Bola pra frente" e a gente dá risada e segue...

E eu sei que tem muitos casos piores que o dela, vejo muita criança na cadeira de rodas, outros intubados, na máquina... Por isso tudo, eu vejo que ela tá boa, tá brincando, pulando, então tá bem, né?

Ricardo demonstrou percepção sobre o estado de saúde frágil da filha, assim como suas respostas reacionais ao tratamento. No entanto, valorizou as formas de ser de Renata, próprias da infância, e o parecer saudável, o que pareceu contribuir para a preservação da esperança e seu enfrentamento.

7.2.3.2 As sessões do procedimento de Desenhos-Estórias e temas emergentes

Encontrei Renata no setor de Radioterapia, antes de sua sessão diária. Aceitou prontamente a ida à sala da Psicologia, mostrou-se animada diante do espaço e, sem que fosse solicitado, sentou-se para desenhar.

\subsection{A história do peixe}

Em sua produção, Renata apresentou desenhos em estágio apropriado a sua fase de desenvolvimento, dotados de significação e simbolismo. Utilizou traços leves e cores, mostrando-se criativa ao buscar dar sentido a sua produção. Ao abordar a disputa entre o bem e o mal, expressou o reconhecimento da ameaça e destacou a possibilidade de cada um lançar mão de recursos internos e externos para enfrentamento. A união e a relação entre os peixes surgiram enquanto tentativa de neutralizar a ameaça à destruição, valorizando a amizade como possibilidade de proteção e resolução do conflito, contraposta à incerteza de sua concretização.

Ao final do procedimento, levantou-se e explorou a sala. Utilizando a lousa branca disponível, recontou a história, desenhando e apagando cada personagem, conforme sua aparição na estória. Diante da proposta de nova realização do D-E, recusou e questionou sobre a possibilidade de olhar os brinquedos. Explorou a sala, sem se ater a nenhum brinquedo, e depois a gente se dirigiu à sala de espera para a sessão de radioterapia. 


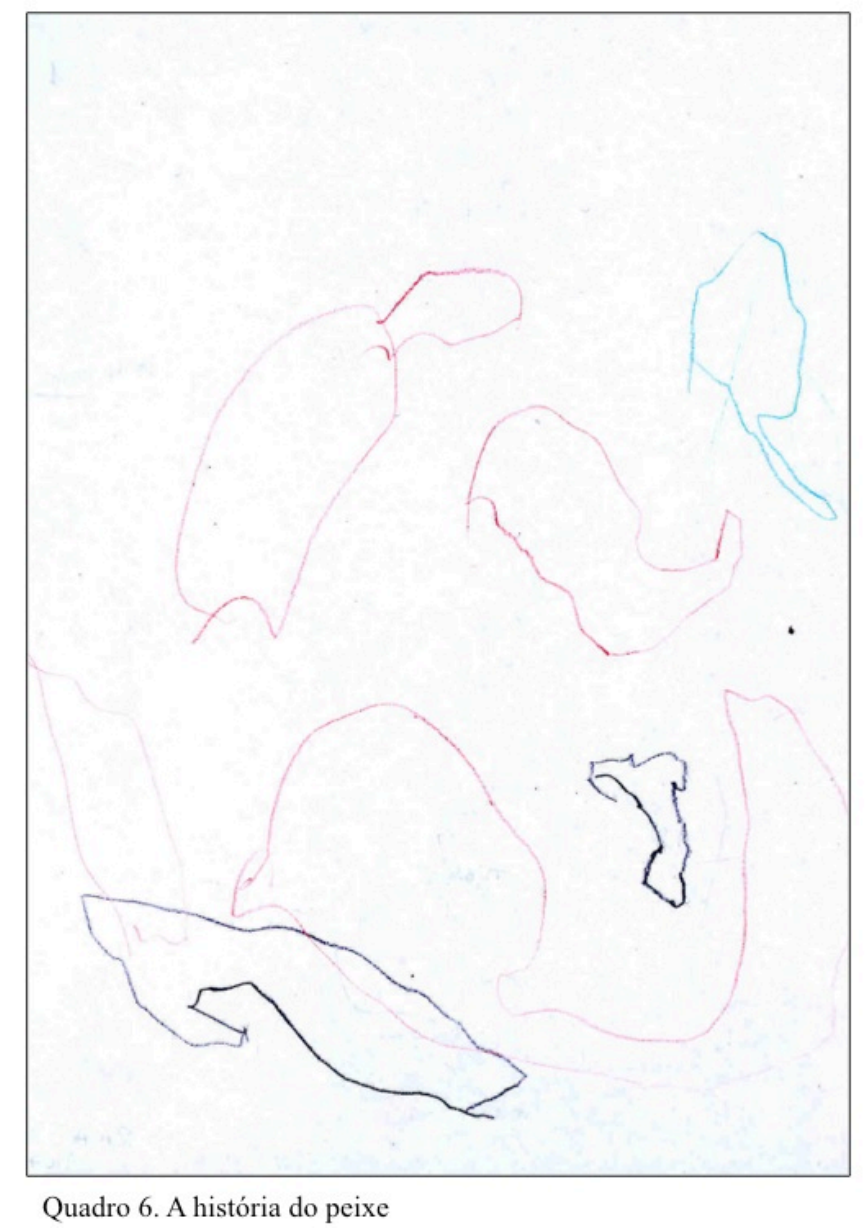

Olha o barco... Esse aqui é o tubarão... E esse é o pato... O tubarão tá atrás do pato [E o que vai acontecer?] Não sei... Esse é o peixe, o peixe-espada... Olha o bico dele... [E o que ele faz com esse bico?] Ele fura... Esse (peixe-espada) é amigo desse (pato) e aí ele vai picar o tubarão, porque o tubarão é mau... [Ele é mau? E o que faz dele mau?] Ele quer pegar o pato... Esse é o peixe, e essa é a baleia... Ela é amiga dele e ele é amigo dele (peixe-espada) e ele é amigo dele (pato). Esse é outro peixe... Ele é amigo deles e fica amigo do tubarão... Aí todos ficam felizes para sempre...

Titulo: A história do peixe.

\subsection{Sem título}

No encontro seguinte, Renata se atentou ao baú de brinquedos, porém aceitou realizar, primeiramente, a atividade proposta.

A segunda unidade de produção de Renata pareceu representar, novamente, a desproteção do mundo e os riscos para a preservação da vida, evidenciando o medo de destruição e senso de impotência diante da ameaça. A figura paterna surgiu como protetora, 
oferecendo amparo e afeto, de forma a permitir o contato com a ameaça. A figura da vovozinha pareceu preservar aspectos da bondade, no entanto, ficou evidente sua desproteção. $\mathrm{Na}$ descrição inicial do conjunto D-E, surgiu a temática da transformação dos animais, diante das perdas e diferenças anatômicas percebidas, que sugeriu sobre a dificuldade de sobreviver com as faltas, impondo a perda de identidade e a busca de alternativas à vivência do adoecimento, à vulnerabilidade e à questão da morte.

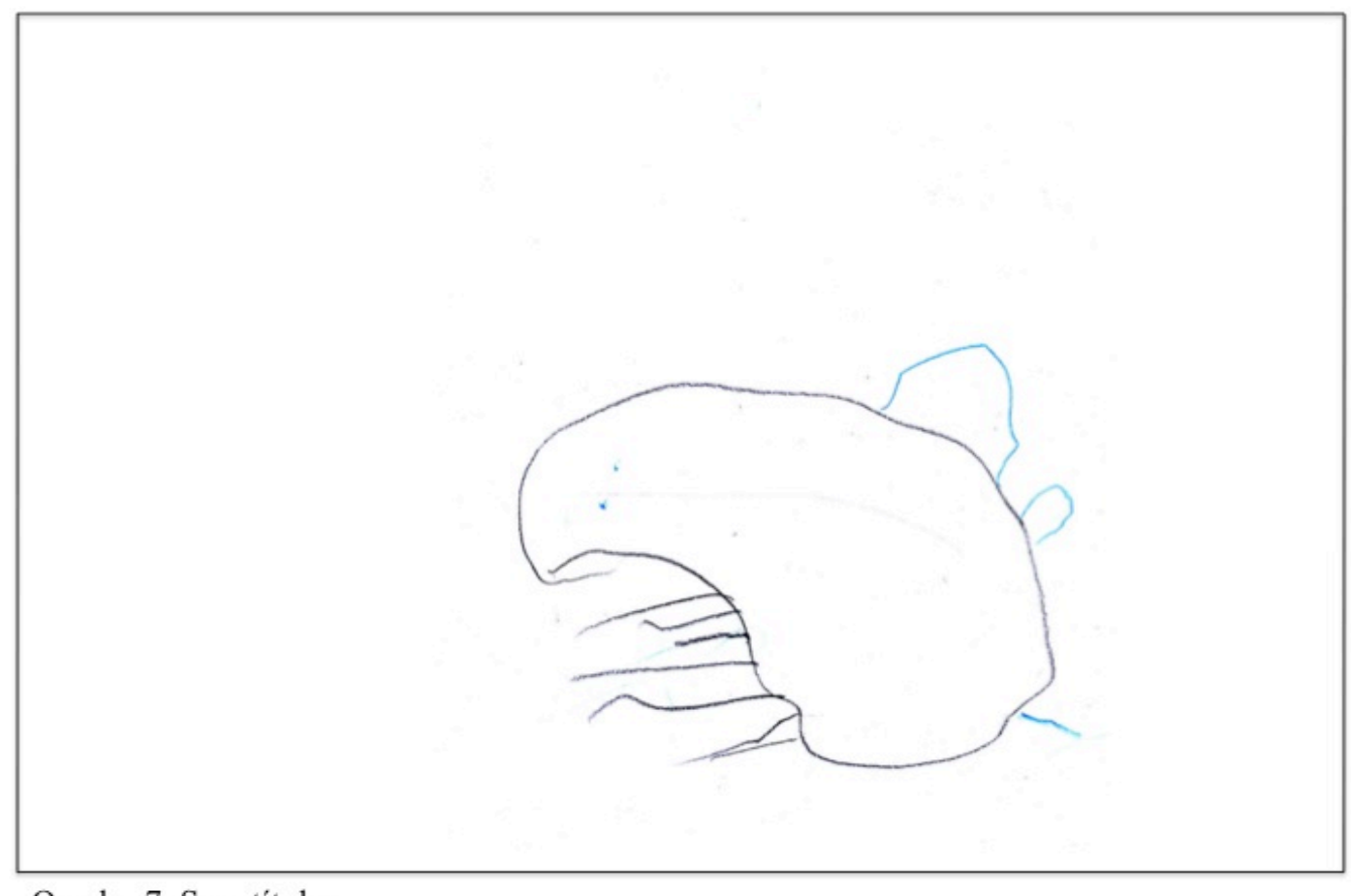

Quadro 7. Sem título

Aqui tem uma baleia... Vira uma formiga bem grandona, tá vendo? [Essa é a formiga?] É! E agora eu vou colorir ela com esse (lápis azul) [E o que é isso que você tá desenhando agora?] É a perna dela... Ela tem 6 pernas... E tá vendo esse furinho bem pequenininho? É o olho dela... E eu vou desenhar o rabo... Olha o rabo... O rabo dela não encaixou direito, olha... [Não encaixou direito? E aí?] Aí vai virar uma abelha! Ela tem essa asa pequenininha e essa asa grandona... [Olha, uma asa é maior que a outra... E o que vai acontecer?] Ela vai voar! [Vai voar?] É, lá pra floresta! [E o que tem nessa floresta?] Tem o lobo mau... Aí ela foi lá no lobo mau... Ela foi visitar a vovozinha... Aí quando o lobo pede para ela pegar uma flor, ele chega rápido e aí come a vovozinha... [Ele come a vovozinha? E o que ela sente?] Ela fica com medo... Vamos brincar? [Ela fica com medo...] Aí o pai da chapéu vermelho tem um negócio assim e o lobo mau fica com muito medo do pai da chapéu vermelho... Aí abelha é amiga da chapéu vermelho... [E o que elas fazem juntas?] Elas brincam... Vamos brincar?

Sem título: "Eu não sei..." 
Mostrou-se pouco receptiva para a investigação do procedimento de DesenhosEstórias, levantando-se antes de sua conclusão para acessar os brinquedos. Renata demonstrou dificuldade em concluir a elaboração da estória e nomeá-la, evidenciando sinais de ansiedade e buscando no brincar possivelmente uma forma alternativa de expressão emocional. Estimulei o retorno à atividade, porém respeitei sua reação e busca lúdica, por avaliar importante naquele momento o espaço de expressão, em vista da mobilização emocional da criança. Assim, foi interrompido o procedimento de coleta de dados, julgando o material coletado rico e a prioridade do bem-estar infantil.

\subsubsection{Síntese compreensiva da díade}

O processo diagnóstico de Renata pareceu prolongado, com lenta identificação de sinais e início do tratamento, com consequente piora clínica e implicações para o prognóstico (Ministério da Saúde, 2008). Evidenciou questões da dinâmica familiar, exigindo sua reorganização e superação de dificuldades na alternância de papéis e construção da identidade paterna no cuidar para atender às novas necessidades da criança, no mundo do câncer pediátrico.

A transição do cuidado pela figura materna para uma maior inserção do homem tem sido abordada na literatura, como consequência das mudanças socioculturais no que tange o papel da mulher na sociedade e suas implicações para a instituição familiar (Amazonas \& Braga, 2006; Gilligan, 1982; Romanelli, 2003). Apesar de a literatura apontar para níveis semelhantes de estresse entre os gêneros no desempenho do cuidado e discreto aumento dos sintomas depressivos nos homens (Bonner, Hardy, Willard, \& Hutchinson, 2007), Ricardo pareceu valorizar seus recursos para a lida com situações novas e aprendizagem, ao refletir sobre as dificuldades enfrentadas neste lugar, tanto no que se refere aos cuidados em saúde da filha, como com preocupações sociais deste exercício. Renata trouxe sinais de segurança e amparo na relação com o pai, sugerindo sobre a qualidade do vínculo estabelecido e sua função diante do momento de tratamento.

A recidiva foi sentida com tristeza e esperança, apesar da compreensão de gravidade e contato com a possibilidade da morte. Ricardo expressou sentimentos diante das más notícias e confronto com os limites terapêuticos. De forma semelhante, a criança evidenciou o reconhecimento da ameaça e dos riscos para a preservação da vida na vivência do adoecimento, com sentimentos de desproteção e vulnerabilidade. Diante da magnitude da ameaça e da incerteza experimentadas, as relações interpessoais pareceram importantes 
recursos de suporte no período para a díade. Para Ricardo, foi marcante o sentimento de desamparo pela distância da rede de apoio familiar. Destacou-se, para a criança, a relação afetiva com o pai, enquanto fonte de segurança e proteção, sugerindo sobre a qualidade do vínculo estabelecido e seu significado neste contexto de adoecer.

Em uma sessão de radioterapia de Renata, foi realizada uma devolutiva ao pai. Foram abordadas as mudanças na dinâmica familiar e sua organização para a oferta do cuidado pertinente em saúde infantil. O pai recuperou as dificuldades do ser pai neste contexto, demonstrando satisfação com seu processo de aprendizagem e por perceber os recursos de Renata para a lida. Além disso, reforçou suas dificuldades em assumir a educação da fillha, reconhecendo o auxílio do setor de saúde mental nas orientações de manejo, sendo reforçados o valor do acompanhamento e a possibilidade de auxílio também no âmbito do desenvolvimento infantil e da própria relação afetiva.

\subsubsection{O encontro com Valentim e sua mãe}

Valentim tinha 7 anos e 1 mês no momento da coleta de dados. Morava com os pais (Vinícius, 32 anos e Vera, 33 anos) e o irmão (Victório, 1 ano e 8 meses), em capital da região Norte do país. Com 1 ano e 7 meses, Valentim recebeu o diagnóstico de Leucemia Linfoide Aguda, tendo realizado o tratamento na cidade de origem. Após 1 ano e 6 meses fora de terapia, foi diagnosticada a recidiva em testículo, quando a criança passou por uma cirurgia de ressecção completa. Em meados de agosto de 2009, a família optou por interromper o tratamento, porém, com o retorno dos sintomas, buscaram novamente avaliação médica. $\mathrm{O}$ encaminhamento para o novo tratamento em Campinas envolveu importante esforço materno, em virtude das experiências nos tratamentos anteriores e crenças religiosas.

Em março de 2011, Valentim iniciou o protocolo ALL-REZ BFM 2002, com programação de quimioterapia e radioterapia, sendo considerada a indicação de Transplante de Medula Óssea autólogo conforme avaliação da resposta ao tratamento em curso. Inicialmente, a criança permaneceu com os pais em casa de apoio vinculada à instituição de saúde e, após 2 meses, o pai trouxe o irmão da cidade natal e alugaram uma residência em região próxima ao hospital. Os pais se alternam entre os cuidados dos filhos, principalmente nas internações. Possuem um comércio familiar na cidade de origem, usufruindo a renda variável para o sustento familiar.

O contato inicial foi realizado com a mãe, por intermédio da psicóloga responsável, durante uma internação hospitalar. Após apresentação dos objetivos, procedimentos e 
aspectos éticos da investigação, Vera mostrou-se receptiva à proposta e concordou com a participação. Em seguida, foi realizado o contato com a criança, com a presença da mãe e da psicóloga responsável. Valentim foi bastante receptivo ao contato, recebendo a proposta de atividade gráfica com entusiasmo. Com a concordância de ambos, foram organizados os períodos de coleta de dados.

7.2.4.1 A entrevista e suas categorias temáticas

7.2.4.1.1 Repercussões psicológicas do diagnóstico oncológico e dificuldades advindas do tratamento

Vera iniciou a entrevista espontaneamente, resgatando vivências relativas ao primeiro tratamento oncológico.

No começo para mim foi mais difícil, né? Porque o Valentim, quando eu descobri, tinha 1 ano e 7 meses.

Só que o Valentim amadureceu muito rápido, porque ele entrou no hospital com $1 a 7 m$, então ele mal chorava... Para você ter uma ideia, ele teve 6 internações no começo, era um sofrimento para mim, mas ele colaborava...

Expressou sentimentos experimentados no lugar de mãe, colocando-se, em alguns momentos, como protagonista do período de tratamento, tanto no que se refere ao chamamento ao tratamento, como no âmbito afetivo. No entanto, valorizou a colaboração e ganho na maturidade do filho que pareceram contribuir para o enfrentamento do período e da própria constituição como pessoa.

Com o crescimento de Valentim, as dificuldades relativas ao período de tratamento pareciam também envolvê-lo, principalmente diante do incômodo percebido e aspectos do manejo terapêutico.

No começo, o Valentim tinha pânico, chorava muito que não queria internar. E aí a psicóloga começou a conversar com ele...

Ele gritava muito, gritava, gritava mesmo, de desespero, e muitas vezes me culpava, que eu era a culpada de ele tá lá, tomando isso...

A expressão emocional intensa e, em alguns momentos, direcionada à mãe pareceu proporcionar sentimentos de culpa e responsabilidade diante do sofrimento que ele experimentava.

Fico tranquila, porque acho que tudo vai do nosso tratamento também, como a gente trata ele, da alimentação, tudo isso ajuda muito... E a gente tem que evitar muitas coisas... Eu tenho 
conversado muito com ele, porque ele quer ficar lá fora, quer ficar brincando, então eu digo que tem que ter um limite para tudo... Ele quer comer presunto, quer comer queijo, quer comer salada, que tudo essas coisas eles não podem, né?

O auxílio recebido pela equipe de saúde mental e a valorização do papel materno nos cuidados pareceram auxiliar no estabelecimento de um senso de potência e no enfrentamento das restrições, enquanto estratégia de cuidado.

\subsection{Recidiva: frustração e a escolha pelo tratamento}

A notícia da recidiva pareceu ser recebida com frustração, perpassando o investimento realizado no tratamento inicial, expectativas e esperanças.

Então, ele fez todo o tratamento, tratou, fez todo o processo que era para fazer e, depois de um periodo, a doença voltou. Depois de todo tratamento, a doença voltou.

Diante da decepção, a criança e sua mãe expressaram sentimentos e questionamentos, em relação à aceitação e ao querer do recomeço do tratamento.

(...) no começo ele não aceitava, não queria internar, ele gritava... Ele já sabia que o processo seria de internação, como era o tratamento, a gente já tinha conversado desde a notícia que tinha voltado...

Para mim, quando descobri o problema dele de novo, que tinha voltado, eu também quase entrei em depressão, engordei muito também. Quando a doença volta, a gente não quer acreditar, né? Então a gente cria uma barreira para nós também, de não querer, de não aceitar ou achar que vai perder, nada vai dar certo, então forma uma barreira negativa.

O conhecimento do tratamento pareceu reaproximá-los ao sofrimento e às dificuldades enfrentadas, trazendo o sentimento de incerteza em relação ao sucesso do tratamento e a ameaça da perda. Neste contexto, em um primeiro momento, optaram por interromper o tratamento, decisão pautada na insegurança experimentada e, possivelmente, nos aspectos emocionais pertinentes à notícia da recidiva.

Aí, só que eu não quis continuar lá em Manaus. Queria procurar outro lugar, que tivesse um recurso melhor, porque, querendo ou não, lá não tem como é aqui, da criança fazer raio X, ter outros tipos de exames para fazer.

Eles já estudam aqui, já sabem o que é pra fazer... Eu pedi muito a Deus para me mostrar um lugar melhor.

E aqui não, aqui as pessoas têm um carinho pelos pacientes, se preocupam com os pacientes... Então, tem horas que a gente descobre que os médicos estão fazendo coisas que a gente não imaginava que eles tavam fazendo, cuidando... 
A exploração por outras possibilidades de tratamento, apesar de dificultar a oferta do tratamento oportuno (Ministério da Saúde, 2008), revelou-se como busca de segurança na oferta do que considerava o melhor tratamento ao filho. A valorização dos recursos em saúde, somados à confiança depositada na seriedade com o qual o tratamento era oferecido na instituição, mostraram-se importantes em sua escolha, proporcionando o desenvolvimento do senso de controle e fortalecimento diante da ameaça.

A familia dele ficou toda contra mim, porque achavam que não precisava vir pra cá, que era muito, mas Deus arruma tudo para nós... Ele arrumou tudo para mim...

No começo foi um pouco dificil para trazer e conseguir falar com a médica e tudo, mas depois ela deu a transferência, aí eu peguei e arrumei minha caixa e viemos... Então Deus, colocou pessoas na nossa vida para nos trazer até aqui...

Apesar das dificuldades impostas pela família e pelos trâmites relacionados à transferência, a mãe continuou implicada em seu objetivo, apegando-se à fé religiosa e à esperança da abertura de novas possibilidades com o tratamento.

\subsection{Comunicação com a criança sobre diagnóstico e tratamento}

A questão da comunicação sobre o processo de adoecimento com a criança revelou significados atribuídos à doença e ao tratamento.

Mesmo antes de falar, ele sabia que ele tinha alguma coisa, que não era bom, que era sério, mas eu sempre mostrei pra ele que não era uma doença, uma coisa ruim, eu tentava não abalar ele...

O ímpeto da comunicação aberta com a criança pareceu partir da equipe assistencial, trazendo sentimentos conflituosos na mãe, de confiança na conduta e desejo de proteção ao filho daquela má notícia.

No começo eu tinha um pouco de receio de dizer, assim olha, você tá fazendo um tratamento que você tem que tratar uma doença, então, tudo isso eu resguardava ele. Então a Dra. [psiquiatra] começou a conversar e falar para ele, mas no fundo eu não queria que ele soubesse...

Eu ficava assustada quando ela falava... Pensava assim, meu filho é tão pequeno, ele não vai entender o que é que ele tem... Mas no fundo ele entendeu... Sempre entendeu...

Então, a primeira vez que a médica falou, eu fiquei um pouco triste, porque no fundo eu não queria que ele falasse, que ele soubesse, mas por outra parte foi bom, porque ele não sabe o que é, mas ele sabe que teve um problema... Eu falo para ele que ele tá curado então, como eu já determinei isso, eu não digo que ele tem, eu digo que ele não tem mais, que tá se tratando... A doença já tá em remissão agora...

Mas me abalava ouvir a voz dele falando "Eu faço um tratamento, eu tenho leucemia"... 
A oscilação foi evidenciada também no que se referia à percepção da compreensão do filho acerca do adoecimento. Ao mesmo tempo em que identificava uma percepção a priori da verbalização explícita, apegava-se à ideia de privação do sofrimento pela ausência da compreensão sobre a gravidade em questão. Deparar-se com outra forma de lida pelo filho trouxe questionamentos quanto a sua compreensão e a possibilidade de um novo velamento da realidade ameaçadora. No entanto, Valentim declarava sua percepção das vivências e nomeava a doença que tanto o assustava.

\subsection{Repercussões familiares: organização e relação conjugal}

Diante do processo de adoecimento de Valentim, a mãe percebe uma maior aproximação entre os familiares e com a religião, apoiando-se na dor compartilhada e em características do filho, como merecedor do afeto.

A minha família também, a gente começou a se unir mais... Nós somos irmãos assim: a gente briga, discute, mas na hora do problema a gente se une...

Ele é uma criança de muitas bênçãos, até minha família mudou muito, a gente tem orado muito, tá mais perto de Deus...

... Eu penso que tanto sofrimento talvez tenha tornado ela [avó materna] uma mulher amarga, uma mãe não tão carinhosa, mas conforme o tempo e tudo que aconteceu, minha mãe se tornou minha amiga, minha amigona mesmo...

Quando questionada sobre o esposo, Vera rememorou aspectos conflituosos da relação e divergências na compreensão sobre adoecimento e fontes de suporte.

Porque, para ele, o medo era de perder ele, como eu também tinha medo... (...) ele não acreditava no que o filho dele tinha, surtou, desde o primeiro tratamento... Ele não conseguia ver o Valentim curado, mesmo vendo o Valentim brincando, o Valentim alegre, sempre bonito... Então ele sempre enxergava doença nele, nunca via ele bem...

Então, às vezes, eu o culpava muito também, porque ele sempre enxergou meu filho doente, então a gente não se unia, a gente discutia, a gente brigava muito, ele me acusava, eu acusava ele, então, era uma maneira de acusação... Então eu sempre tive um peso nas costas de ouvir que o Valentim nasceu assim porque eu sou culpada, porque eu tinha uma anemia também, então ele me culpava, sempre tive um peso muito grande nas minhas costas... Uma pessoa que não confia em nada, não acredita em nada, ele tem que ver para ele acreditar, entendeu?

Diante da ameaça da perda instaurada pelo adoecimento, pareciam buscar os responsáveis pelo sofrimento familiar, com situações pouco favorecedoras do encontro e apoio mútuo. Nesse contexto, surgiram sentimentos de culpa e responsabilização, própria e depositada ao outro, que pareciam ampliar a dor. 
E hoje em dia, graças a Deus, eu e meu marido a gente já conversa mais, ele já viu que o que eu fiz, o que Deus me mostrou, é certo, que, como ele mesmo falou, se tivesse lá talvez ele não estivesse como ele tá aqui...

A boa resposta do tratamento de Valentim atual pareceu fortalecer o senso de potência materno e resgatar o vínculo de confiança do casal, com vistas à aproximação familiar para a nova batalha.

A gente vai revezando...Hoje eu vou dormir aqui, ai amanhã quando meu marido vier ele traz o Victório e eu volto com ele... Porque também tem que cuidar da casa, né? Tem que limpar, deixar tudo arrumadinho, para não ficar nada empoeirado... E o Victório fica bem com o pai, ele cuida dele direitinho, dá o mama dele direitinho, ele até gosta de ficar com o pai, então eu fico tranquila...

Com a mudança de cidade, houve a necessidade de uma nova organização familiar. Nesse sentido, as modificações relacionais e o compartilhamento do cuidado com os filhos e das responsabilidades mostraram-se importantes para o equilíbrio emocional.

\subsection{Estratégias de enfrentamento}

Ao longo da entrevista, ficou evidente o suporte encontrado na fé, desde a confiança no fortalecimento para a superação de dificuldades, a revelação de bons caminhos e a oferta de tranquilidade e esperança para a caminhada.

Deus tem me dado muita força... Estou sendo uma mulher de fé que eu nunca imaginei ter a fé que eu tenho hoje... E quem conversa com o meu filho, graças a Deus, sente nele também a fé que ele tem agora, entendeu? Antes eu aconselhava ele, hoje quem me aconselha é ele...

Então, eu falo para ele "Se Deus abriu as portas e mostrou o caminho, é este o caminho" A gente tem sempre que viver o hoje, que o amanhã, só a Ele pertence... E vamos fazendo a nossa parte...

(...) então tive que conversar muito com ele e conversei muito com Deus, para que ele me acalmasse, me tranquilizasse, para que eu continuasse tendo a fé que eu nunca deixei de ter... Para eu passar isso para o meu filho também... Pra ele começar a buscar Deus, para começar acreditar que hoje a gente está aqui, mas amanhã pode voltar para casa...

Tal apreço pareceu ser compartilhado por Valentim, no relato de sua mãe sobre o interesse em tornar-se padre. A vida religiosa pareceu trazer significados de boa criação e certo valor pessoal.

É porque o Valentim já decidiu que ele não quer namorar, ele mesmo já decidiu o propósito da vida dele e ele quer se tornar um padre, mas no começo meu marido achava que eu tivesse incentivado ele a isso, mas eu nunca disse que eu queria que ele fosse alguma coisa ou outra... Eu só queria educar ele na fé, sabendo de Jesus, ouvindo a palavra de Deus, para que ele se tornasse uma criança de bem, uma criança educada, mas com o tempo quem decidiu foi ele... 
Além da fé, a mãe demonstrou valorizar seus próprios recursos para favorecer a resposta ao tratamento do filho.

Eu fiquei sim contente com esse elogio [da médica], porque é uma coisa assim que ela tem visto no Valentim, que meu tratamento e o amor assim que a gente dá para ele, tudo ajuda no tratamento...

Eu percebo que eu aprendi a passar uma segurança para ele, compreendeu?

Eu acho que a gente tem que procurar transmitir para ele uma tranquilidade, mesmo na hora dificil, procurar sempre deixar eles tranquilos...

Somadas às suas contribuições para o bem-estar infantil, destacou ainda a atenção de Valentim para com a mãe e seus sentimentos, oferecendo a Vera momentos de cuidado.

Às vezes a gente tenta esconder alguma coisa dele, mas ele é esperto, observa... Até o meu olhar ele sabe, quando estou bem, quando estou triste... E ele fala pra mim "Mãe o que a senhora tem?", me abraça, canta para mim... risos... Me sinto até mais leve, quando vejo ele passando por tudo isso... Porque na vida da gente é assim: um dia a gente tá bem, outro não tá e a gente vai levando né?

Muitas vezes eu chorei na frente dele, muitas vezes desabafei com ele, mas ele sempre tava ali para me consolar... Eu não tenho só um filho, eu tenho um amigo do meu lado, graças a Deus...

Tem dia que acorda meio assim, mas logo tá dançando como se não tivesse tomado nada que fizesse ele fica mal... Ele me dá essa alegria...

A percepção da forma de enfrentamento no tratamento pelo filho pareceu auxiliá-la a ressignficar as dificuldades e abrir-se às possibilidades desta experiência.

7.2.4.2 As sessões do procedimento de Desenhos-Estórias e temas emergentes

Valentim mostrou-se bastante comunicativo durante as sessões, excitado com a produção criativa. Enquanto desenhava, trazia informações sobre suas inspirações e descrevia o desenho em si.

\subsection{A ponte do amor}

Diante da proposta da atividade, Valentim pouco hesitou, iniciando sua primeira produção.

Já sei [Começa a desenhar] Agora você já sabe, né? [Uhm, o que você desenhou?] Essa a qui é a Rapunzel. [Volta a desenhar] Esse aqui é muito fácil que eu tô desenhando... [pausa] $E$ o jovem cavaleiro. Aqui é a bruxa, querendo que o cavaleiro não pegue a Rapunzel, mas o cavaleiro tentou... E igual a da história da Bela Adormecida, que a Malévola não foi convidada 
pela festa, ai ela entra e no final o cavaleiro tenta passar pela bruxa, mas a bruxa se transforma num dragão. Mas o príncipe ainda consegue matar ela...

O primeiro desenho teve traços fortes, com riqueza de detalhes e pertinência com a estória. No entanto, percebeu-se a ausência de membros nos desenhos de todas as figuras, que sugeriu sobre a passividade, ausência de apoio e sustentação experimentadas. Valentim assumiu uma postura de aceitação na primeira unidade de produção, marcada pela preocupação com o êxito na luta entre o bem e o mal, diante do conflito básico representado pela morte.

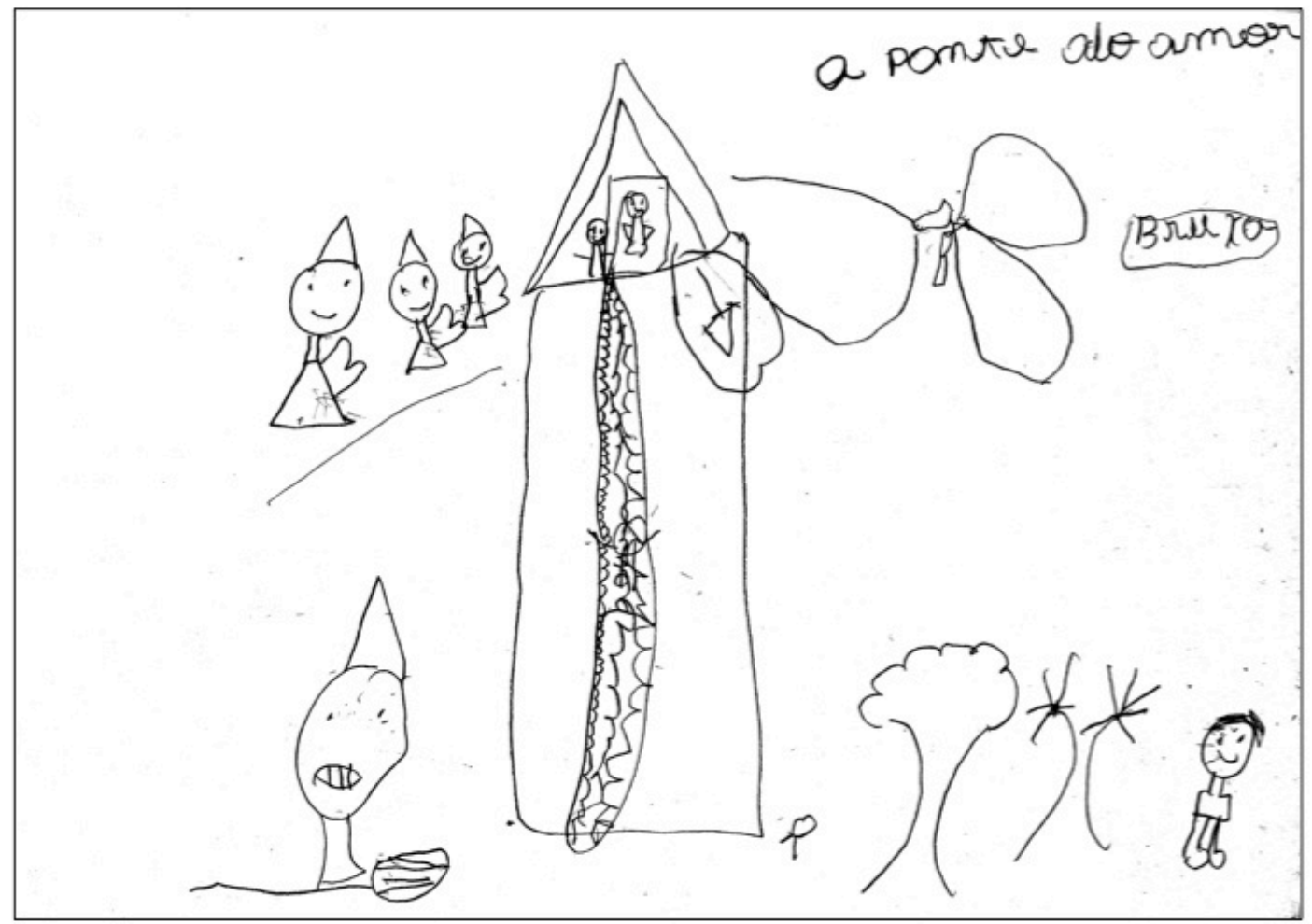

Quadro 8. A ponte do amor

Aqui é assim... Ela [bruxa] vai tentar virar um dragão para não deixar que o príncipe pegue ela [Rapunzel], mas se ele conseguir matar a bruxa, ele consegue pegar a Rapunzel de primeira. [Então ele tem que lutar com a bruxa para tentar pegar a Rapunzel?] É [E o que ele tá sentindo?] Sentindo, como? [De sentimento mesmo] Amor, claro. [É por amor que ele quer pegar a Rapunzel?] Isso. [E na hora de enfrentar a bruxa, como ele se sente?] Sente de maldade. [Como assim?] Ela vira um dragão, ué. E ele consegue matar a bruxa para salvar a Rapunzel. [Ele consegue matar a bruxa, então?] É... É igual à história da Bela Adormecida, vou te contar toda a história então. É bem assim: No começo, ela se encontra com o príncipe, que o nome dele é Felipe. Aí, a bruxa não foi convidada para a festa, aí joga um encanto assim: "Essa menina entrará no castelo, enfiará o dedo numa roca e morrerá". Aí, mas a bruxa 
azul consegue tirar o encanto, assim "Ela não morrerá, mas dormirá num sono profundo até que um beijo a acordará”. Aí o príncipe vai e passa por todos os lugares, mas a bruxa se transforma num dragão, aí ele pega, não tem a faca? Ele pega e joga no coração do dragão. Aí o dragão some de primeira, some! Aí ele vai subindo pelas escadas, aí dá um beijo nela e eles se casam... Eles se apaixonam... Eu também sei a da Bela e a Fera... No começo, é assim, o pai dela vai pra bem longe, mas ó que ele encontra um castelo, ele fica perdido... Aí ele encontra o castelo da Fera, aí depois a Bela vai lá no castelo da Fera, não sabe que a Fera é um príncipe encantado por uma bruxa. Não tem aqueles desenhos lá, que tem uma vela tudinho? Também são humanos. As cadeiras, tudinho são humanos. Aí se a Bela beijasse a Fera o encanto sairia de todos, aí todos viraram humanos. Mas só que tinha um problema, eles primeiro tavam se conhecendo e ficava toda a torcida pra ela se apaixonar por ele... (Entra enfermeiro para administrar medicação, V. acrescenta desenho) Não é princesa, viu? Essa aqui é a chefona, mas aí no final da história, as fadas levam a Bela Adormecida para elas e ela dá outro nome para a Bela, dá Rosa. Mas a Bela não sabe que ela é princesa, ninguém conta pra ela, só conta quando ela chega em casa. Aí quando ela chega em casa, as fadas contam que ela é uma princesa, aí ela fica desesperada, vai para o quarto e vai chorando para o quarto. Aí ela ficou com o Felipe e no final ficam felizes para sempre, aí é engraçado no final, que ela pega a varinha, aí uma bota vermelha e a outra azul... [Troca a cor... E aqui, neste desenho, o que as fadas vão fazer?] Elas vão dar o dom. Essa daqui dá a beleza, essa daqui dá o amor... A Malévola vem, né? E essa daqui tira o encanto da bruxa... Era um encanto assim: ela botava o dedo na roca e morrerá, mas só que essa fada tirou o encanto, disse: "Ela não morrerá, mas só que dormirá num sono profundo até que um beijo de amor acorde ela"... [E o que acontece depois?] Aí a fada fica azul, vermelho, azul, vermelho... Por exemplo, essa daqui é azul e essa daqui vermelha, dai essa daqui acha que o azul fica mais bonito e essa acha que o vermelho que fica, aí fica azul, vermelho, azul, vermelho... [E como é que termina essa história?] No final eles ficam dançando no baile, felizes...

Título: "A ponte do amor"

A realização do seu desejo de crescimento, desenvolvimento e sexualidade surgiu interditada pela figura da bruxa, fazendo-se necessária a luta em busca de um amor que salva e que tudo supera. A ameaça de morte foi atenuada por um "sono profundo", com abertura à possibilidade de resolução do conflito por meio do amor, em alusão a questões da recuperação da saúde e vida. Além disso, valorizou a proteção oferecida pelos outros no cuidado da protagonista, assim como suas próprias ferramentas nesse sentido. Enfrentar a situação de 
adoecimento pareceu difícil e perigoso, porém aos poucos, o clima afetivo inicial de tensão foi substituído pelo sentimento de gratificação e conquista no desfecho.

Ao final da estória, questiona-se sobre algo a acrescentar e Valentim diz que tinha muitas estórias para contar.

\subsection{O mundo encantado de Marina}

Valentim iniciou sua segunda produção, buscando criar certo ar de suspense e sedução afetiva.

Fica parada... Aqui não é ninguém não, é tu... Tá ansiosa? [Estou curiosa] Oh pra ficar bonito, eu vou desenhar uma coisa aqui. Adivinha o que é! [O que é?] Uma bolsa! Seu nome qual é? [Marina] Espera aí... [O que você escreveu aí?] Marina De amor Valentim.

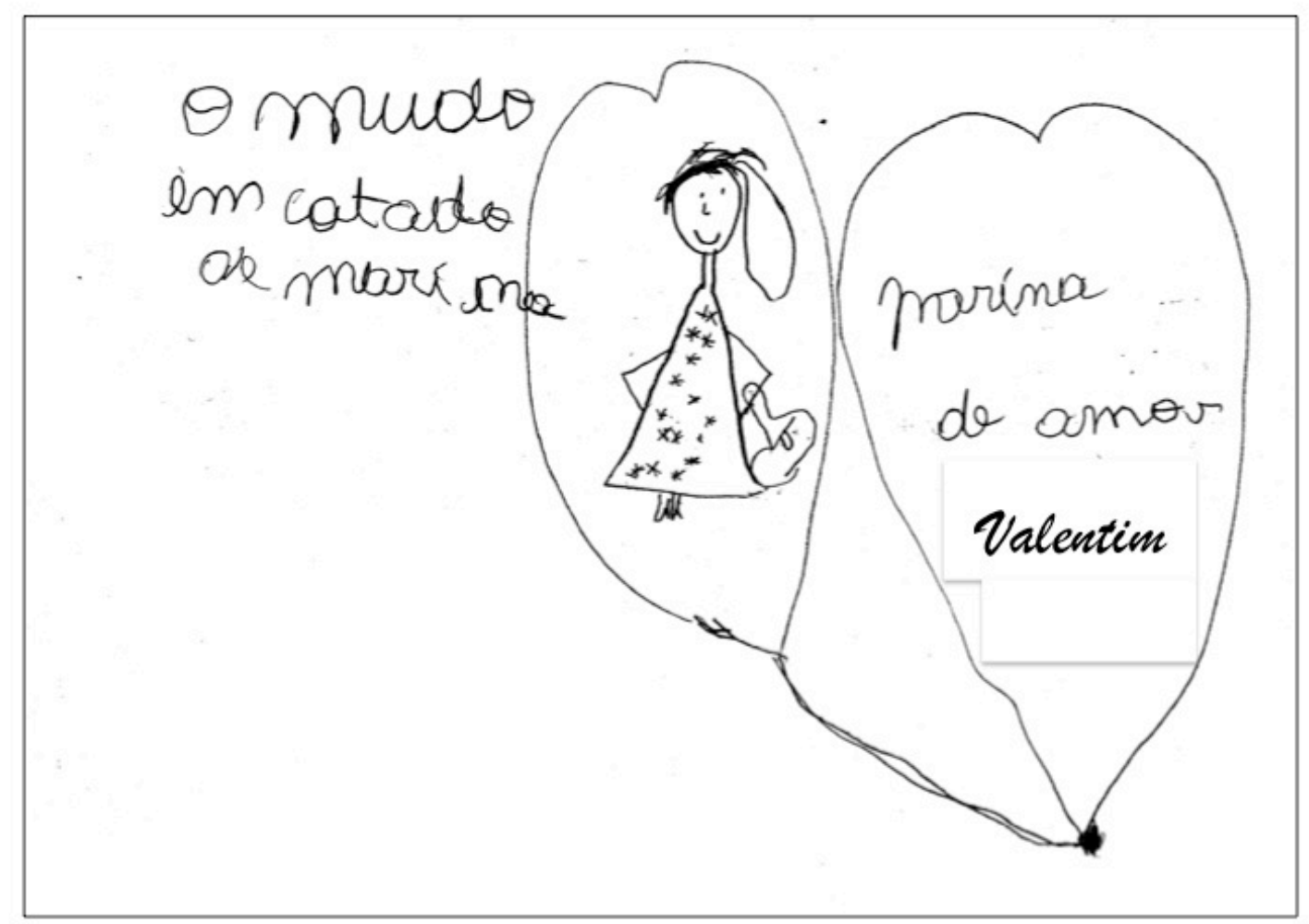

Quadro 9. O mundo encantado de Marina

É assim, primeiro tu tá indo pro baile... Aí se encontra com alguém, eu não sei dizer muito, tá? [Não se preocupe... A história é sua, pode ser do jeito que você quiser] Depois você conheceu alguém... Tu fica simpática... Aí depois vai embora para casa, aí depois se encontra com ele de novo... Aí depois você ficava e aí namorava... [É uma história de amor?] É... Eu tenho um filme, de "Ponte para Terabítia, já assistiu?" [Não, como é?] É assim, ele tem uma irmã, aí pega, né, ela vai atravessar o rio numa corda... Primeiro ela atravessa, 
depois ele... Aí depois, eles vão voltar para o outro caminho, que vai ter outra corda para atravessar, aí quando ela vai atravessar, a corda cai, aí ela se afoga e ela morre... Aí vai ter que enterrar ela, todo mundo fica desesperado... É um filme ennnnnnnncantável! Aí, ele pega e fala assim para uma garotinha "Feche os olhos" Ela fecha e aparece um mundo todo encantado assim... Todo com brilho, castelo... E a menininha vai ser coroada... Quando eu falar com o meu pai, eu vou te mostrar... Ela morre porque a corda cai, aí quando a corda caiu, ele tentou encontrar ela, mas ele não conseguiu encontrar... Aí ele pensou que ela fícou perdida na mata, mas só que ela morreu... Aí quando soube que ela morreu, foram enterrar ela e ficou só ele... É assim, tem a ponte, né? Que ele já tá te dizendo: "Ponte para Terabítia", aí tem uma ponte assim que vai, aí eles atravessam a ponte todinha e aí ele fala: "Fecha os olhos", que aparece um gigante, mas é do mal não, é do bem... Aí ele junta ela e quando ela vê, ela fica toda assutada com o mundo, que era todo encantado... Eles vão até lá, até o mundo... [E aí?] Aí, no final, eles ficam lá nesse mundo, da ponte para Terabítia... [E como ela se sente quando chega lá?] Mas não é a irmã dele não... [Não, é a outra garotinha, certo?] Certo... Aí eles constroem uma casa na árvore, por exemplo, vem um ladrão, aí eles sobem para a casa na árvore... Eu sempre quis construir uma casa na árvore... Ainda mais que vou ser padre... Mas aí eles encontram um monte de bichinhos, só que é besouro do mal, besouro falante, aí eles enfrentam a águia, enfrentam o porco-espinho, os besouros e enfrentam o gavião. [E como é a luta?] A luta é assim: eles lutam sem nada, mas só que o cara tem escudo e uma arma. Assim, a arma de espada, assim, eles vão lutar com os bichos... Aí, depois que eles lutam, eles se perdem na mata, vão para outro lugar, se perdem na mata, aí não tem cobra, aí pega, ele mostra também para a irmã dela, aí depois eles vão embora... Aí quando a irmã dele morre, aí pega e mostra o mundo encantado para a outra menina... Aí ela fíca assustada... [E como ele se sente quando a irmã morre?] Ele fica triste... [E essa história do desenho?] Eu vou te contar... Isso aqui que eu fiz é uma cartinha, pra ti... Uma cartinha que eu fiz... [E que história essa carta conta?] Não tem história nenhuma não... Não sei... Eu sou muito criança para entender essas coisas...

Título: O mundo encantado de Marina

Em sua segunda unidade de produção, Valentim trouxe vivências conflituosas em relação à sexualidade (como em "vou ser padre", "sou muito criança para entender essas coisas", "não tem história nenhuma") que pareceram remetê-lo à lembrança de aventura, suspense e riscos disponíveis no contato com o outro e com o mundo, sugerindo sobre sua vivência ambivalente diante das relações amorosas e das incertezas na projeção ao futuro. 
Trouxe sua percepção do filme "Ponte para Terabítia" que relata a história de amizade entre duas crianças que, utilizando da fantasia e da criatividade, descobrem um mundo encantado, no qual conseguem enfrentar todos os medos e as dificuldades encontradas no mundo real. Valentim abordou a luta e as dificuldades percorridas para chegar até o mundo encantado, onde encontraria tranquilidade e a beleza da vida que parecem semelhantes às questões pertinentes ao percurso de adoecimento e suas ameaças. No entanto, colocou esse mundo encantado como da pesquisadora, sugerindo o desejo de estar em uma relação afetiva e viver situações que, neste momento, não se revelam disponíveis para sua experiência. $\mathrm{O}$ amor é para Marina, cada qual está em um coração, apesar do elo reforçado que os une, sugerindo sobre a importância do vínculo e relacionamento afetivo.

No filme, a morte da amiga trouxe ao protagonista a vivência de sentimentos de culpa, tristeza e impotência, retratando aspectos de seu processo de elaboração do luto. Nesta unidade de produção, Valentim evidencia certa confusão diante da temática da morte, com idas e vindas no relato da história, pontuando sobre as dúvidas sobre sua concretização e de como se seria aquela realidade. O contato com a morte de alguém muito próximo pareceu remetê-lo às vivências e aos questionamentos de sua própria morte, a qual o contato direto seria muito ameaçador. As relações com as figuras fraternas proporcionaram sentimento de desproteção e ameaça, contrapostos ao suprimento afetivo e senso de potência que vislumbra na temporalidade do futuro, mesmo que incerto.

\subsection{A gosma preguiçosa}

Valentim realizou sua terceira produção em silêncio. Em seguida, teceu comentários a respeito de seu personagem e elencou outras possibilidades de produção, resgatando situações vivenciadas no ambiente hospitalar.

Essa gosma é preguiçosa, só gosta de assistir desenho, não faz mais nada... Eu queria desenhar uma cartinha para a mamãe... Uma vez eu desenhei uma cartinha para a mamãe e levaram a pastinha embora...

Cabe esclarecer que, na instituição hospitalar em questão, cada criança internada recebe uma pasta com materiais gráficos, repostos regularmente. Acolhi seu desejo de realizar a carta e propus que esta fosse realizada após a elaboração da estória do material.

O desenho apresentou-se com traçado forte, mais primitivo e com menor riqueza de detalhes, se comparado às produções anteriores. A cor lilás, símbolo da espiritualidade e trancendência, surgiu apenas no corpo da protagonista, enquanto foco de expressão emocional 
e necessidade de proteção. Emergiu, na terceira unidade de produção, a temática da despersonalização e da postura passiva diante da vida, o que indicou sobre sua vivência diante do adoecimento, no qual se estabelece uma relação de confiança e de dependência ao outro. As reações de medo e desespero se mostraram ínfimas se comparadas à ameaça de desintegração e de morte experimentadas. As dificuldades enfrentadas no mundo real e a fragilidade emocional pareceram direcioná-lo ao mundo da fantasia, representado pelo filme “O mundo das fadas", enquanto alusão a aspectos de tranquilidade e equilíbrio que remete aos significados atribuídos à fantasia no Desenho-Estória anterior.

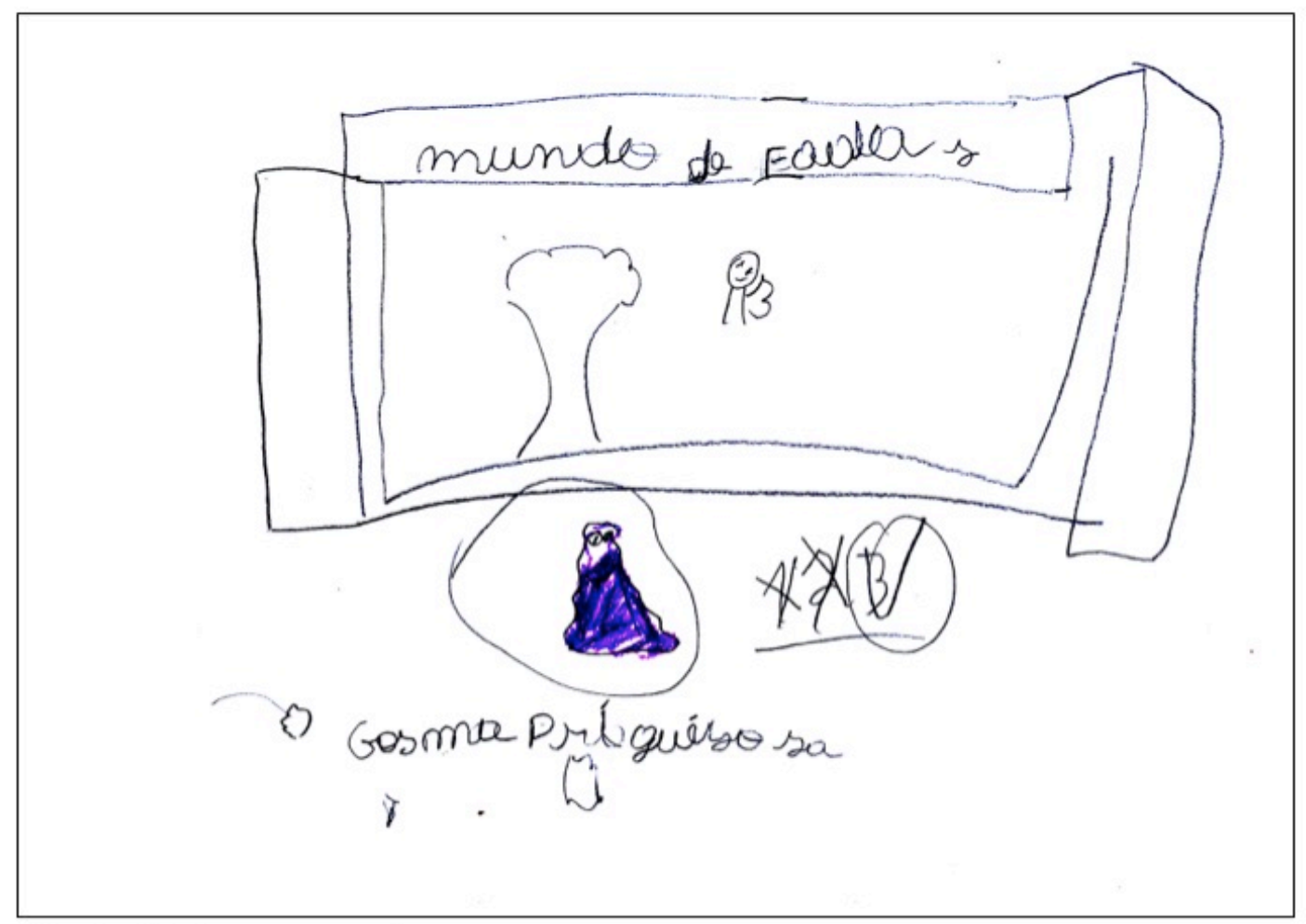

Quadro 10. A gosma preguiçosa

É assim, a gosma tá no cinema... Aí foi e o filme acabou... Aí pegou e colocou outra fita de filme, ligou e assistiu outro sozinha... Foi pegando, foi pegando, foi pegando até cansar... Quando cansou, ela foi embora, espreguiçou e deitou no sofá... [E aí?] Isso que a gente fala, se chama preguiça... Preguiça, eu sei um bom remédio para tirar isso aí dela... Um banho, gelado... Mas se ela tomar banho, ela derrete... [Derrete?] E vai pro esgoto... [E o que acontece?] Ela fica em pedacinho... [E o que ela sente?] Não sei... Vamos ver assim: pergunta 1. Você vai ter que adivinhar, porque eu sei... Será que ela tem medo de água? Pergunta 2: Será que ela fica apavorada? Pergunta 3: Será que ela desmancha em pedaços? [O que você acha, Valentim? Você me disse que já sabe...] Tem que adivinhar... Eu vou 
repetir... Pergunta 1: Será que ela tem medo de água? Pergunta 2: Será que ela não tem medo? Pergunta 3: Será que ela desmancha, desaparece? [Você não vai me ajudar? - Faz que não com a cabeça - Então vou começar pela primeira: Acho que ela tem medo de água... Usa onomatopeia para resposta errada. Ela não tem medo de água?] Não... Pergunta 2: Será que ela fica apavorada? [Eu acho que não... - Usa onomatopeia novamente para questão errada] E a 3 é certa, porque ela desaparece! [E aí?] Aí ela desaparece e não aparece mais... Porque ela é uma gosma... Gosma é assim: a água desce e limpa a gosma... Por exemplo assim, a casa tá suja, cheia de gosma, aí vamos jogar água na casa, que a gosma sai... Aí, quando joga água na casa, a gosma desaparece totalmente, porque a água foi derramada... Aí a gosma desaparece e não aparece nunca mais... [E aí?] Aí ela vai para o esgoto e fíca lá com os ratos... [E o que ela acha de ir para o esgoto?] Eu não sei da vida da gosma [Como ela se sente?] Eu não sei da vida da gosma [Consegue imaginar?] Não... [E como termina essa história?] Ok. A 3 é a correta, eu vou até desenhar... A água vai ser derramada para lá, aí quando a água foi derramada para lá, sabe o que acontece? A gosma fica assim: um pedaço para cá, outro pedaço para lá... Porque a água foi derramada... Aí ela desaparece totalmente... Ela fica assim, igual geleia... Ela fica mole... Aí a água derrama, ela fica mole e desaparece totalmente... Eu estudei, risos...

Título: A gosma preguiçosa

\subsection{O pé doente}

Na segunda sessão, Valentim demonstrou o mesmo entusiasmo. Inicialmente, fez o desenho de um avião, simulando um jogo dos erros.

Sabe o que eu sei desenhar? Avião [E você tem vontade de desenhar um avião?] Vou desenhar para você ver... Isso aqui é um avião, mas só que é diferente que esse... Esse tá com janela e esse tá? [Sem janela] Igual jogo do erro... Esse tá com esse piloto e esse tá sem? [uhm] Piloto! Agora, o que que tá faltando nesse avião? Tá fácil, você sabe... [O que tá faltando?] A asa! Agora eu vou fazer outro jogo do erro... [Você quer me contar uma história desse desenho primeiro?] Não tem história, risos... [Será?] Tá bom... Tá decolando! [Então ele vai voar?] Vai... Você não trouxe tinta? [Não trouxe...] Ah, que esquecida! [A gente combinou que esses desenhos seriam com lápis de cor e você disse que gosta] Eu gosto, mas, às vezes, é bom variar...

Demonstrou dificuldade em elaborar uma estória, apesar de interagir com sua produção por meio do lúdico. Percebeu-se uma continuidade da temática das perdas pela situação de ameaça e de morte, contrapondo o saudável/doente, a vida/morte e avião inteiro/com ausências. As partes faltantes pareceram relacionar-se a condições básicas da vida 
e de possibilidade de escolha, como protagonista da própria vida. Diante da mobilização emocional, buscou outros assuntos e emendou na realização de um novo desenho.

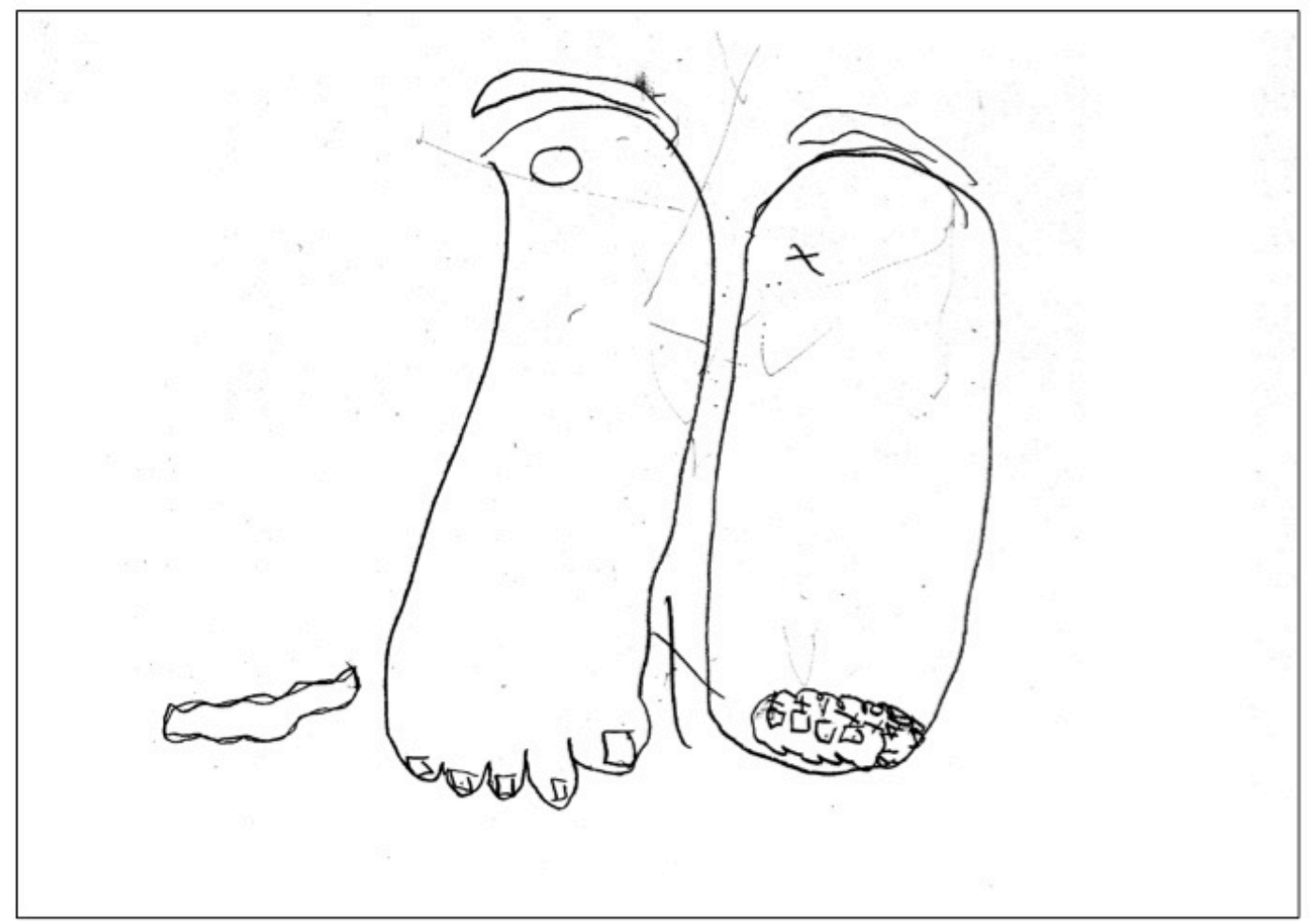

Quadro 11. O pé doente

Eu vou desenhar um pé... risos A unha tá encravada... Parece pé de bruxa... Você sabe o erro? [Que erro?] Você sabe sim... Aqui tem um tornozelo e aqui não tem... Já te ajudei um, qual é o outro erro? [Falta o contorno desse pé?] Acertou... Faltou um dedo na hora de fazer o contorno... O dedo vai ser tudo aberto, risos [Vai ficar aberto? E o que acontece?] Aparece o osso do pé... [E aí, V?] Fica vazando sangue pela casa... Aí a pessoa morre! Mas tem jeito de costurar... Já fez cirurgia? [Não] É fácil, eu já fiz cirurgia... Eles abrem o pé, por exemplo aqui... A pessoa tem um tumor, né? Aí eles pegam, abrem o corpo da pessoa, aí tira aquele bichinho lá e joga fora... Aí eles veem naquele binóculo lá, como é? [Microscópio?] É, o bichinho que tem... Aí eles pegam e costuram com agulha o que eles fizeram e aqui fica costurado... Aí tem que ficar de repouso um tempão de dias... [E depois, o que acontece?] Depois quando sara, some aquela cirurgia, aí pode brincar o tanto que você quiser... [E com esse pé, o que vai acontecer?] Não sei! Risos Vai ter que ficar de repouso... [E quem é o dono desse pé?] Ihh Já sei o que falta nesse pé... [O que é?] Aqui tem um chulé... E aqui não tem... É um pé de cada dono! Esse pé [com chulé] é do papai... [E esse outro?] O que tá aberto? É o meu... Claro, porque eu já fiz cirurgia... [E onde esses pés estão indo?] Na casa 
do Chico [Chico?] Nem sei, eu não conheço... risos [Eles vão juntos?] É... [E quantos anos têm esses pés?] Uns 1.030... [Eles são mais velhos, então...] Não é bom isso, porque daí os pés viram fantasmas! [E o que acontece?] Não sei... Eu não sei da vida dos fantasmas... Primeiro eles estão indo pra casa do Chico, daí esse pé sente uma dor enorme! Aí eles vão no médico, aí eles abrem o pé e costuram o pé... Aí depois que costurou o pé fica de repouso... Aí depois quando sarou, ele e pode brincar... [E a dor?] Passou... [E o que ele achou de ficar de repouso?] Nada bom... Não podia se mexer, não podia nada! Foi assim que eu fiquei...

Título: O pé doente

7.2.4.2.5 O encontro do amor

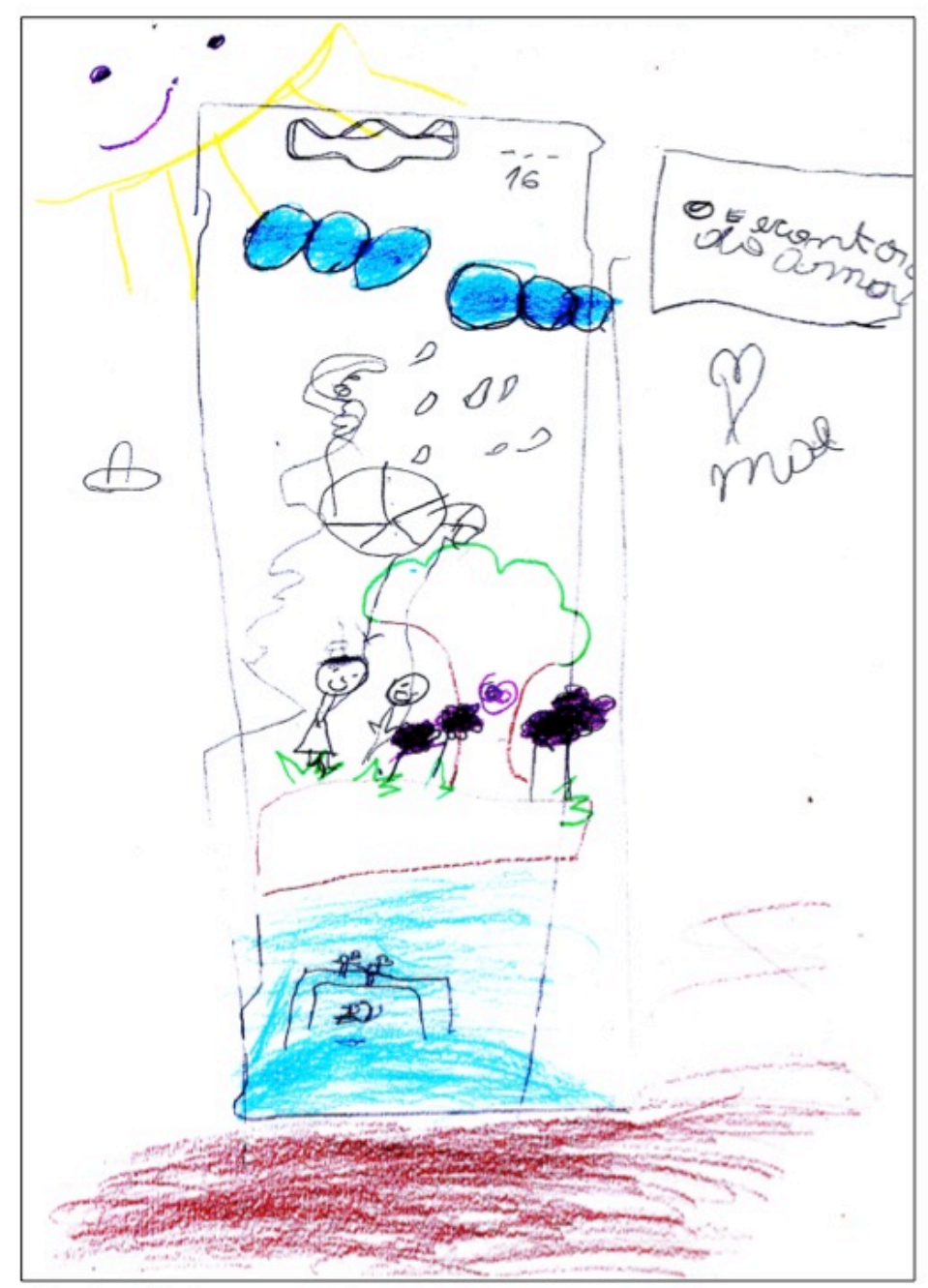

Quadro 12. O encontro do amor

Adivinha o que eu desenhei? [Uhm não sou muito boa de adivinhação... O que você desenhou?] Aqui é uma cachoeira e aqui uma ponte... [E aqui?] Minha mãe e meu pai... [E o 
que tá acontecendo?] Não sei, risos... Adivinhou? [Eles estão se beijando?] Acertou! Em cima da ponte... Esse tronco vai na cachoeira... Já pensou se tivesse um furacão de água? [O que iria acontecer?] Ia afogar todo mundo! [E aí? Como eles iam ficar?] Afogados, eles iam morrer... [E iam sentir o que?] Não sei... [Continua o desenho] Aqui é a mamãe e o papai, eles estão numa floresta... Aí eles marcaram um encontro aí... Vou te mostrar tudo... Aqui é o mar, aqui é o sol, aqui são as nuvens, aí a floresta no mato... Aí eles pegaram... Não sei contar história direito... Aí marcaram encontro e foram para casa... Aí na manhã seguinte eles se casaram... Aí a mamãe teve eu e depois o meu irmão e eles formaram uma família... A minha família é assim: a minha avó, meu tio, minha tia, meu irmão... Em casa, ele queria ficar nu, pelado! E deixaram! Eu não achei nada bom! A pessoa pelada, dançando e pulando em cima da cama, ainda ouvindo o CD da Aline Barros... Nada bom... [E aqui, o que eles estão sentindo?] Amor... Aqui você sabe que é terra, né? [Ah... E o que eles vão fazer depois daí, desse passeio na floresta?] Vão para casa! [E a árvore? Quantos anos ela tem?] 70. [E se ela fosse uma pessoa, o que você acha que ela ia sentir?] Não ia sentir nada, igual o mágico de Oz... O homem de lata, ele viveu, mas só que ele queria ter coração para sentir... O espantalho queria ter cérebro e a menininha queria ir de volta para casa... Adivinha o que é isso? Vai espalhar por toda a Terra... [O que é isso?] Chuva! Aqui é o raio atingindo! [O raio atinge eles?] Não, atinge a Terra... [Ah... E o que acontece?] Depois ele some... [E a chuva?] Não se preocupa não... [Desenha um guarda-chuva] Porque eles têm um guardachuva... [Uhm Então não precisa se preocupar porque eles têm proteção] É... E aí [Desenha flores] Nasceu... Mas não tem a cor que eu quero, rosa escuro... Acho que vou ter que usar o roxo... [E como eles se sentiram quando viram as flores nascendo?] Acharam bom... [E elas, o que aconteceu?] Cresceram e viraram um... Tá desenhado aí... (Aponta a árvore) [Ah Uma árvore... E aí?] É assim, uma semente, a gente coloca na árvore e rega... Aí nasce o sol, o sol atinge a semente, a semente nasce uma plantinha e vai crescendo, crescendo... Quanto mais fazer isso, vira uma flor, aí vai nascendo frutos e a flor vai crescendo, crescendo até virar uma árvore... [E o que ela precisa para isso?] Regar, molhar, deixar no sol, aí ela vai crescer devagar... [E do que você acha que essa flor mais precisa?] Do sol e da água... [E quantos anos elas têm?] A flor não tem idade, só as árvores... [E como termina?] Aí nasceram as flores, aí eles vão para casa, se casam e vivem felizes para sempre...

Título: "O encontro do Amor"

Durante sua quinta produção, Valentim abordou superficialmente a decisão de tornarse padre, conforme discurso prévio da mãe e terceira unidade de produção de D-E. 
Marina, você é casada? Tem filho? [Não. E você?] Eu não, eu vou ser padre. [E como você se decidiu?] Fiquei falando, falando, falando até que decidi...

$\mathrm{Na}$ quinta unidade de produção, os desenhos apareceram com cores fortes e riqueza nos detalhes, favorecendo a expressão emocional. Abordou a história da relação afetiva dos pais e a construção da família, demonstrando curiosidade em relação à vida a dois e à sexualidade, ao mesmo tempo em que expressava medos e preocupações associadas. Além disso, evidenciou o sentimento de exclusão desta relação, trazendo o questionamento sobre o lugar ocupado por esse filho na vida familiar. Em um segundo momento, após a família constituída, vivenciam novo clima de ameaça, porém a percepção de recursos de enfrentamento e do amor pareceu auxiliar no alívio das ameaças, favorecimento do crescimento e do sentimento de felicidade.

\subsubsection{Síntese compreensiva da díade}

A busca pelo tratamento em centro de excelência de atenção a doenças oncohematológicas revelou aspectos das dificuldades enfrentadas no primeiro tratamento, no âmbito técnico e emocional, assim como sobre o movimento materno em busca de maior segurança (e esperança) diante das incertezas advindas com a comunicação da recidiva. Além disso, a fé assumiu papel importante no enfrentamento dos momentos de crise e incerteza, parecendo favorecer posturas de segurança e persistência.

A mãe pareceu implicar-se no tratamento, colocando-se também enquanto protagonista, de forma a reforçar a questão das ressonâncias emocionais do período para a família como unidade de cuidar e pertinência da assistência psicológica estendida aos familiares (Araujo, 2006; Campos et al., 2007; Hinds et al., 2002; Lopes \& Valle, 2001; Oliveira et al., 2005). Nesse sentido, a hesitação quanto à comunicação aberta com seu filho também pareceu permeada por seu próprio sofrimento emocional e dificuldades na aceitação da realidade da doença, sendo as reações do filho, de compreensão e de coragem, fonte de surpresa e inspiração à mãe.

A incerteza do prognóstico do segundo tratamento e a ameaça da morte pareceram trazer implicações às vivências emocionais da díade. Valentim expressou a percepção do clima de tensão emocional e ameaça de desintegração, contrapostos ao desejo de crescimento e vitalidade. Perceberam-se importantes repercussões psicológicas nas relações familiares, notadamente na relação parental, com predomínio de relações de desconfiança e culpabilização que, com o passar do tratamento e do processo de reorganização, pareceram 
ceder lugar ao apoio e à união. No entanto, emergiram na expressão infantil questionamentos sobre o lugar da criança na unidade familiar, fazendo pensar sobre questões do vínculo e estabilidade nas relações. A confiança na equipe de referência e na apropriação das possibilidades terapêuticas pareceu auxiliar a lida da família com a situação conflituosa, favorecendo a projeção para a temporalidade da cura, assim como a abertura a novas temáticas e conflitos próprios da etapa de desenvolvimento da criança, reforçando sobre o papel da equipe na mediação do enfrentamento familiar (Espíndula \& Valle, 2002; Hockenberry-Eaton et al., 1995; Mu et al., 2001).

A devolutiva foi realizada com a mãe que esteve bastante comunicativa. Foram abordados a percepção das estratégias de enfrentamento, utilizadas pela díade diante da situação de recidiva, e o investimento na busca por tratamento e por um maior senso de segurança. Isa enalteceu a força percebida em seu filho e o valor desta postura para seu próprio enfrentamento, permeado por um sentimento de satisfação também de sua função de mãe nesse sentido. Ao final do contato, foi resgatada a referência ao setor de saúde mental e seguimento já estabelecido, considerando as ameaças presentes nas vivências de ambos e os recursos simbólicos da criança.

7.3 Reflexões sobre a experiência familiar e infantil diante da recidiva em Oncologia Pediátrica

Ao final da apresentação dos dados, torna-se importante a tentativa de integração dos cuidadores e das crianças diante da experiência da recidiva, a fim de possibilitar um olhar global acerca do fenômeno estudado. Nesse sentido, serão discutidas temáticas emergentes nos contatos com os cuidadores-familiares e com as crianças e, por fim, a atenção voltada à relação estabelecida entre as díades.

7.3.1 Aproximação com as vivências dos cuidadores-familiares

A vivência dos cuidadores-familiares diante da recidiva oncológica de seus filhos se revelou a partir de três temáticas fundamentais: (1) Senso de ausência de controle, (2) Percepção de ameaças e (3) Ressignificando as possibilidades de cuidado. 
7.3.1.1 Senso de ausência de controle

A literatura especializada defende o diagnóstico precoce e o tratamento oportuno como fatores prognósticos (Ministério da Saúde, 2008). No entanto, Gabriel e Renata perpassaram um período de idas e vindas, com diferentes hipóteses diagnósticas e tratamentos ineficazes, o que pareceu atrasar o início do tratamento e trazer implicações emocionais às suas cuidadoras.

Quando adoeceu, ele tava vomitando muito... Levei ele no postinho e disseram que ele tava com virose... Passou um mês e ele não melhorava... Teve febre e levei no hospital que eu trabalhava, disseram que ele tava com pneumonia e receitaram um monte de antibióticos, mas a febre não passou... Ele foi ficando pálido, a barriga inchou e essas glândulas do pescoço também... Pensaram que podia ser leptospirose e pediram uns exames para confirmar... Quando eu voltei pra buscar o exame percebi diferença no tratamento da equipe comigo, estavam mais carinhosos, cuidadosos, sabe? A médica chegou e disse que tinha uma alteração no exame e encaminhou pro Boldrini... Eu chorei até, porque fiquei muito assustada, eu já tinha ouvido falar do hospital e do que tratava aqui... Ela disse que era cedo pra falar alguma coisa, que ele precisava ser avaliado aqui no Boldrini primeiro... (Giovana, 34 anos, mãe do Gabriel)

Mas ai com três anos quando ia subir a ladeira ela começou a sentir fraqueza nas pernas... E com uns três anos e meio começou a sentir dores, a não comer... Ai que eu levei ela no médico pra ver o que tava acontecendo e começou a tratar infecção de urina, anemia... (Ricardo, 32 anos, pai da Renata)

E eu já tinha comprado um monte de antibiótico pra ela e nada, assim, de ficar boa... Ai quando foi um dia, eu pedi pra ele internar, porque já tava avançando, né, pedi pra ele internar... (Ricardo, 32 anos, pai da Renata)

No caso de Valentim, questões relacionadas à percepção maternal sobre os aspectos técnicos do tratamento disponível na região de origem e dificuldades no encaminhamento também prejudicaram a oferta do tratamento oportuno.

Ai, só que eu não quis continuar lá em Manaus. Queria procurar outro lugar, que tivesse um recurso melhor, porque, querendo ou não, lá não tem como é aqui, da criança fazer raio $X$, ter outros tipos de exames para fazer. (Vera, 33 anos, mãe do Valentim)

Eles já estudam aqui, já sabem o que é pra fazer... Eu pedi muito a Deus para me mostrar um lugar melhor. (Vera, 33 anos, mãe do Valentim)

Cabe ressaltar que as dificuldades encontradas na rede assistencial implicaram no deslocamento territorial dos participantes, em âmbito regional e interestadual, a fim de possibilitar o tratamento. Com isso, uma reorganização psicossocial foi exigida dos familiares, o que envolveu questões relacionadas ao trabalho dos pais e renda, frequência escolar dos pacientes e irmãos, além da adaptação ao novo contexto sociocultural e do adoecimento, em sintonia com estudos de Lopes e Valle (2001). No caso de Renata, tais 
aspectos implicaram em alterações nos papéis familiares, tendo o pai assumido seu cuidado principal, até então garantido pela avó paterna.

Assim... A mãe dela não quis vir, né, a minha mãe é senhora já e não podia vir, até porque ela tem nervoso, né? E minha mãe não ia aguentar, porque não é todo mundo que aguenta... Inclusive, acho que nem a mãe da Renata ia aguentar... A médica até falou que normalmente quem vai é a mãe, mas eu disse que não é o caso da Renata. (Ricardo, 32 anos, pai da Renata)

Assim, além do estresse descrito na literatura acerca do diagnóstico e tratamento oncológicos (Bruce et al., 2011; Dunn et al., 2012; Hockenberry-Eaton et al., 1995; Mu et al., 2001), essas famílias tiveram essa outra tarefa, não menos exigente, para a organização do cuidado.

Diante do diagnóstico de recidiva oncológica, perceberam-se sentimentos de tristeza e frustração de expectativas de cura, promovendo importante senso de vulnerabilidade e ausência de controle, além da ruptura em suas projeções para a vivência familiar na temporalidade de cura.

Ai, a hora que a gente acha que vai, que ia voltar pra casa e se reorganizar, vem outra cacetada. Você acha que a gente dá conta? Ele ficou 5 meses fora de terapia e agora a gente vai recomeçar... (Paula, 39 anos, mãe do Pablo)

Ia terminar em dezembro o tratamento, mas em outubro voltou a doença... Foi outro baque, bem pior do que na primeira vez, porque a gente tava contando os dias para acabar com aquilo tudo! (Giovana, 34 anos, mãe do Gabriel)

Foi uma conversa nada agradável, né? Mas não tem outro jeito... Primeiro a gente fica triste, tem que ficar mesmo... Fiquei uns três, quatro dias triste... Mas depois não adianta, né? Igual lá em Rio Branco, fiquei triste, mas depois fiquei alegre de pensar que ia tratar... E aqui a gente fica mais triste porque tá só eu e ela, né? Sozinho, sem saber o que vai acontecer... (Ricardo, 32 anos, pai da Renata)

Para mim, quando descobri o problema dele de novo, que tinha voltado, eu também quase entrei em depressão, engordei muito também. (Vera, 33 anos, mãe do Valentim)

A ausência de controle sobre a saúde do filho e sobre o itinerário terapêutico surgiu na reflexão dos motivos da doença e seu retorno, contrapostos ao desejo pela criança e à percepção de saúde e alegria dos filhos.

Ele foi muito bem-vindo e aguardado pela família toda... E é isso que me faz perguntar "Da onde um câncer?" Nunca imaginei que uma criança tão desejada fosse ter tanto problema... (Paula, 39 anos, mãe do Pablo)

Então eu sempre tive um peso nas costas de ouvir que o Valentim nasceu assim porque eu sou culpada, porque eu tinha uma anemia também, então ele me culpava, sempre tive um peso muito grande nas minhas costas... Uma pessoa que não confia em nada, não acredita em nada, ele tem que ver para ele acreditar, entendeu? (Vera, 33 anos, mãe do Valentim)

Associado a esses questionamentos, percebeu-se que os cuidadores assumiram para si a responsabilidade de proteger seus filhos e, com o insucesso de barrar o adoecimento, 
evidenciaram sentimentos de culpa. Forghieri (1993) situou a culpa como inerente à existência humana. A autora explicitou sua emergência em decorrência da percepção do homem quanto à impossibilidade de realizar todas as suas potencialidades, dando espaço para a falta.

\subsubsection{Percepção de ameaças}

Da mesma forma que no estudo de De Graves e Aranda (2008), perceberam-se nos cuidadores-familiares a oscilação entre a esperança de cura, com ações direcionadas ao tratamento e superação das adversidades, e a ameaça existencial imposta pela possibilidade da morte, fortalecida pela experiência de insucesso no primeiro tratamento, consciência dos riscos pertinentes ao tratamento e as incertezas relativas ao prognóstico. A impossibilidade de escolha e orientação para o futuro trazidas pela doença grave pareceram amplificar nos pais o sentimento de impotência e fracasso, dificultando a oferta de sentido à existência (Valle, 1997).

Porque eu posso cuidar o tempo todo dai e fico perto... Vamos dar tudo para ele, fazer tudo, mas no fundo eu sei que não adianta... (Paula, 39 anos, mãe do Pablo)

Faço bem feita a minha parte, porque eu não quero ter culpa depois... Quero ter certeza de que fiz tudo que estava ao meu alcance e eu sei que estou fazendo... (Paula, 39 anos, mãe do Pablo)

A gente precisa ter alguma coisa para se apegar e Deus tá sempre presente nos momentos da nossa vida, principalmente nesses mais dificeis... Ele que nos dá força para seguir e acreditar que vai dar certo... (Giovana, 34 anos, mãe do Gabriel)

A morte, apesar de ser a única certeza da existência humana, surgiu como a grande ameaça para esses pais, com significados de fracasso e impotência, dificultando sua ressignificação e aceitação. Como lembrou Forghieri (1993), em algumas situações, o homem obtém um senso de controle, mesmo que momentâneo, em relação ao mundo circundante, porém, não se sustenta diante da morte.

Mas eu prefiro que ele morra do que ter que passar por isso outra vez... Não que eu queira, pelo contrário, mas eu sei da dificuldade de tratar... (Paula, 39 anos, mãe do Pablo)

Então, teve tempos tranquilos, mas teve vez de eu achar que não ia levar a Renata pra casa... Porque de cada 8, só um escapa dessa infecção que ela teve... A hospitalar, sabe? Até a médica falou "Pai, eu pensei que o Sr. ia sem a Renata... Foi grave, gravíssimo"... (Ricardo, 32 anos, pai da Renata)

Quando a doença volta, a gente não quer acreditar, né? Então a gente cria uma barreira para nós também, de não querer, de não aceitar ou achar que vai perder, nada vai dar certo, então forma uma barreira negativa. (Vera, 33 anos, mãe do Valentim) 
A experiência da morte de outras crianças em tratamento pareceu concretizar a possibilidade da perda do próprio filho, em fase delicada do tratamento, trazendo a vivência de luto antecipatório.

E acho que a experiência com o Igor [paciente falecido há 2 semanas] influencia... Eu tento separar as experiências, mas é diferente, porque quando se fala de câncer tudo é possivel... (Paula, 39 anos, mãe do Pablo)

Ao estudar evidências do processo de luto em pais de crianças com câncer, Al-Gamal e Long (2010) identificaram tal vivência maior no diagnóstico inicial, do que quando comparada a momentos posteriores do tratamento. O relato dos cuidadores-familiares entrevistados sugeriu que a recidiva se caracterize também como um momento crítico e com potencial de aproximar das vivências de perda, merecendo atenção especializada para o cuidado emocional.

\subsubsection{Recomeço: ressignificando as possibilidades de cuidado}

Outra temática transversal no relato dos cuidadores-familiares foi a imposição de revisão das formas de cuidar, nesse novo contexto de incertezas.

Mas acho que depois que você vive com essa ameaça do câncer do seu filho, a gente muda a maneira de ver as coisas... Dá mais valor pras coisas mais simples, a gente vê tudo com outros olhos... (Paula, 39 anos, mãe do Pablo)

... O que que a pessoa não aprende? A pessoa aprende a estudar, aprende outras coisas, eu também não sabia de nada não, aqui que eu tô aprendendo... A pessoa aprende, o mundo ensina... (Ricardo, 32 anos, pai da Renata)

A preocupação extrema com as orientações médicas pareceram ser balanceadas com o desejo de aproveitar a vivência do momento atual, de forma condizente com os achados de estudos internacionais (De Graves \& Aranda, 2008).

Ai agora, no segundo tratamento, eu tenho vontade de fazer tudo hoje, como se não fosse dar tempo se deixar pra depois... (Paula, 39 anos, mãe do Pablo)

Então, eu falo para ele "Se Deus abriu as portas e mostrou o caminho, é este o caminho" A gente tem sempre que viver o hoje, que o amanhã, só a Ele pertence... E vamos fazendo a nossa parte... (Vera, 33 anos, mãe do Valentim)

Inserido nas preocupações com o cuidado, destacou-se não apenas o cuidado ao filho adoecido, mas também à unidade familiar. A necessidade de reorganização psicossocial para oferecer o tratamento à criança, além de toda a questão relacionada ao processo saúde-doença, 
implicou na mudança de cidade, em questões financeiras e nas relações afetivas, em sintonia com estudos de Lopes e Valle (2001).

Desde isso de não trabalhar, ter que vir no hospital e se desdobrar, até a presença do Paulo mesmo... Antes ele saía 5 h30 para trabalhar e voltava às $20 \mathrm{~h}$... Agora a gente fica $24 \mathrm{~h}$ juntos... Por um lado é bom, mas é estranho também... A convivência é maior, os atritos também... (Paula, 39 anos, mãe do Pablo)

Fica sempre sem a gente, sem o irmão, sem mim... Tá terrivel, desobediente, dando muito trabalho... Percebo que ele fica triste quando o Gabriel interna... É dificil... Tento ter mais paciência, mas não é fácil... (Giovana, 34 anos, mãe do Gabriel)

Foi dificil né? Você imagina, largar mulher, filha, trabalho, amigos, tudo lá no Acre e vir? Mas eu deixei bem claro pra ela "Olha, eu tô indo, mas pra cuidar da outra filha" e o importante é que ela tá bem e a outra também, ficou com a mãe... (Ricardo, 32 anos, pai da Renata)

A gente vai revezando...Hoje eu vou dormir aqui, ai amanhã quando meu marido vier ele traz o Victório e eu volto com ele... Porque também tem que cuidar da casa, né? (Vera, 33 anos, mãe do Valentim)

Os cuidadores relataram seus esforços no sentido do reequilíbrio da dinâmica familiar, ainda que fosse difícil o contato com os sentimentos da criança, dos seus próprios e dos familiares. Reconhecer os limites e sofrimento individuais, diante dessa fase de tratamento, pareceu favorecer a valorização do suporte familiar e social.

O dinheiro pesa, mas o que mais pesa é o relacionamento, porque se um não apoiar o outro, não tem jeito... (Paula, 39 anos, mãe do Pablo)

Eles choraram bastante quando souberam da recidiva e tentam nos apoiar de alguma forma, mas tá todo mundo abalado... Mas vai passar, a gente sabe que uma hora tudo acaba... (Giovana, 34 anos, mãe do Gabriel)

A minha família também, a gente começou a se unir mais... Nós somos irmãos assim: a gente briga, discute, mas na hora do problema a gente se une... (Vera, 33 anos, mãe do Valentim)

Além desses tópicos, a religiosidade emergiu como recurso de fortalecimento e cuidado ao cuidador, em sua busca pela adaptação diante das incertezas do período.

Eu penso “Meu Deus, ele teve fungo, mas ele tem o Senhor"... (Paula, 39 anos, mãe do Pablo)

Eu peço que Deus me dê forças e mostre o caminho... (Giovana, 34 anos, mãe do Gabriel)

Graças a Deus, Deus nunca abandonou a gente... Por mais que a gente esteja só, a gente nunca tá sozinho, Ele sempre tá com a gente, tem que ter fé... Mesmo a gente não sendo nenhum santinho, né, porque eu não sou... Peço a Deus pra dar força pra gente, saúde pra ela, não só pra nós dois, mas pra todas as crianças que eu vejo... (Ricardo, 32 anos, pai da Renata)

Deus tem me dado muita força... Estou sendo uma mulher de fé que eu nunca imaginei ter a fé que eu tenho hoje... (Vera, 33 anos, mãe do Valentim)

Assim, a experiência da recidiva pelos cuidadores-familiares esteve permeada pela mudança no paradigma de cuidado, iniciado pela constatação da ausência de controle sobre o itinerário terapêutico de seu filho, associada à incerteza sobre o futuro e suas ameaças. 
Articular tais temores pareceu favorecer a ressignificação das relações estabelecidas com a doença e com o cuidado em saúde dos seus filhos, ampliando a gama de sentidos disponíveis, de forma a auxiliar na organização para o recomeço.

7.3.2 Aproximação com as vivências das crianças

Na expressão gráfica-verbal infantil, destacaram-se duas vivências principais diante do momento que experimentam: (1) Percepção de ameaças e (2) Busca de proteção e afeto que serão discutidos e articulados a seguir.

\subsubsection{Percepção de ameaças}

A percepção de ameaça esteve presente em todos os participantes, acompanhada pela vivência de fragilidade, desamparo e solidão. Em suas produções, as crianças abordaram sobre sua percepção dos riscos na relação com o mundo e os desafios que enfrentam diariamente, ou nas situações de adoecimento e tratamento ou no âmbito emocional, o que reforça os achados de Hockenberry-Eaton et al. (1995) sobre a apreensão infantil das questões relativas à realidade e à incerteza.

Tá sentindo que vai chover (Pablo, 7 anos e 6 meses, Desenho-Estória 2)

(...) porque se chove a lama vai aumentar muito e onde a galinha está vai alagar... (Gabriel, 10 anos, Desenho-Estória 1)

Esse é o peixe, o peixe-espada... Olha o bico dele... [E o que ele faz com esse bico?] Ele fura... (Renata, 5 anos e 2 meses, Desenho-Estória 1)

Ela vai voar! [Vai voar?] É, lá pra floresta! [E o que tem nessa floresta?] Tem o lobo mau... Aí ela foi lá no lobo mau... Ela foi visitar a vovozinha... Ai quando o lobo pede para ela pegar uma flor, ele chega rápido e aí come a vovozinha... [Ele come a vovozinha? E o que ela sente?] Ela fica com medo... (Renata, 5 anos e 2 meses, Desenho-Estória 2)

Aí, a bruxa não foi convidada para a festa, aí joga um encanto assim: "Essa menina entrará no castelo, enfiará o dedo numa roca e morrerá "(Valentim, 7 anos e 1 mês, Desenho-Estória 1)

É assim, ele tem uma irmã ai pega, né, ela vai atravessar o rio numa corda... Primeiro ela atravessa, depois ele... Aí depois, eles vão voltar para o outro caminho, que vai ter outra corda para atravessar, ai quando ela vai atravessar, a corda cai, ai ela se afoga e ela morre... (Valentim, 7 anos e 1 mês, Desenho-Estória 2)

Preguiça, eu sei um bom remédio para tirar isso aí dela... Um banho, gelado... Mas se ela tomar banho, ela derrete... [Derrete?] E vai pro esgoto... [E o que acontece?] Ela fica em pedacinho... (Valentim, 7 anos e 1 mês, Desenho-Estória 3)

Já pensou se tivesse um furacão de água? [O que iria acontecer?] Ia afogar todo mundo! [E aí? Como eles iam ficar?] Afogados, eles iam morrer... (Valentim, 7 anos e 1 mês, Desenho-Estória 5) 
A experiência do tratamento foi abordada diretamente por Gabriel e Valentim, significada com sentimentos de isolamento e de privações.

Aqui morava uma linda princesa, que o pai não deixa sair de casa, mas também não é hora de sair... Tá chovendo muito e ela iria molhar o vestido, né? Mas nem eu saio daqui, fico só nesse quarto de hospital, sem videogame... Continuando... Ela não saía por nada, ela gostava de ficar no castelo, tinha lindas flores uma de cada cor da natureza... [E como ela se sente?] Triste, é uma tortura! (Gabriel, 10 anos, Desenho-Estória 2)

Ai depois que costurou o pé fica de repouso... Ai depois quando sarou, ele e pode brincar... [E a dor?] Passou... [E o que ele achou de ficar de repouso?] Nada bom... Não podia se mexer, não podia nada! Foi assim que eu fiquei... (Valentim, 7 anos e 1 mês, Desenho-Estória 4)

Apesar de apenas uma das crianças, Valentim, ter feito menção ao adoecimento e a certa etapa de tratamento, percebeu-se nas crianças um movimento de expressão da vivência das perdas e da possibilidade da morte no outro, sugerindo sobre a dificuldade no contato direto com a própria situação de saúde.

Esse é meu avô [Seu avô?] Pai da minha mãe. (...) [E quantos anos ele tem?] Nem sei, já tá de dentadura! (Pablo, 7 anos e 6 meses, Desenho-Estória 1)

Aí quando o lobo pede para ela pegar uma flor, ele chega rápido e aí come a vovozinha... (Renata, 5 anos e 2 meses, Desenho-Estória 2)

Ai depois, eles vão voltar para o outro caminho, que vai ter outra corda para atravessar, aí quando ela vai atravessar, a corda cai, ai ela se afoga e ela morre... Ai vai ter que enterrar ela, todo muito fica desesperado...(Valentim, 7 anos e 1 mês, Desenho-Estória 2)

O dedo vai ser tudo aberto, risos [Vai ficar aberto? E o que acontece?] Aparece o osso do pé... [E aí, Valentim?] Fica vazando sangue pela casa... Aí a pessoa morre! (Valentim, 7 anos e 1 mês, Desenho-Estória 4)

Diante da ameaça percebida, as crianças simbolizaram a necessidade constante da luta entre o bem e o mal, buscando recursos internos e apegando-se às relações com os outros para superar os desafios impostos.

Esse [peixe-espada] é amigo desse [pato] e ai ele vai picar o tubarão, porque o tubarão é mau... [Ele é mau? E o que faz dele mau?] Ele quer pegar o pato... (Renata, 5 anos e 2 meses, Desenho-Estória 1)

Aí o pai da chapéu vermelho tem um negócio assim e o lobo mau fica com muito medo do pai da chapéu vermelho... (Renata, 5 anos e 2 meses, Desenho-Estória 2)

Ela [bruxa] vai tentar virar um dragão para não deixar que o príncipe pegue ela [Rapunzel], mas se ele conseguir matar a bruxa, ele consegue pegar a Rapunzel de primeira. (Valentim, 7 anos e 1 mês, Desenho-Estória 1)

Mas aí eles encontram um monte de bichinhos, só que é besouro do mal, besouro falante, aí eles enfrentam a águia, enfrentam o porco-espinho, os besouros, e enfrentam o gavião. [E como é a luta?] A luta é assim: eles lutam sem nada, mas só que o cara tem escudo e uma arma. Assim, a arma de espada, assim, eles vão lutar com os bichos... (Valentim, 7 anos e 1 mês, Desenho-Estória 2) 
A percepção de conflito não se restringiu às vivências de seu mundo próprio, abrangendo também a vivência da percepção de suas ressonâncias no contexto familiar.

Todo mundo vai se esconder em casa, o pato vai também, ele não vai ficar aqui fora sozinho! (Pablo, 7 anos e 6 meses, Desenho-Estória 2)

Já pensou se tivesse um furacão de água? [O que iria acontecer?] Ia afogar todo mundo! [E aí? Como eles iam ficar?] Afogados, eles iam morrer... (Valentim, 7 anos e 1 mês, DesenhoEstória 5)

Dessa forma, expressaram-se sobre os riscos que assombram as famílias, assim como a desorganização percebida, buscando estratégias para a redução dos danos, ao mesmo tempo em que oferecem sentidos, com vistas à elaboração psíquica.

\subsubsection{Busca por proteção e afeto}

Com a percepção da ameaça, as crianças pareceram envolver-se na exploração de possibilidades de proteção. Empenharam-se em investimentos direcionados à vitalidade, reforçando a disponibilidade de recursos psíquicos para o enfrentamento da situação de ameaça e adaptação ao processo saúde-doença.

[Pega os lápis de cor e constrói uma casa sobre o papel] Pronto! Deu certo! [Agora eles estão protegidos?] Agora sim. (Pablo, 7 anos e 6 meses, Desenho-Estória 2)

Esse é o peixe, o peixe-espada... Olha o bico dele [E o que ele faz com esse bico?] Ele fura...(Renata, 5 anos e 2 meses, Desenho-Estória 1)

Não se preocupa não... [Desenha um guarda-chuva] Porque eles têm um guarda-chuva... (Valentim, 7 anos e 1 mês, Desenho-Estória 5)

Além disso, valorizaram o papel do apoio familiar e social, sugerindo sobre os benefícios da rede de apoio na superação de questões pertinentes ao dia a dia do tratamento, assim como de suas implicações psicológicas. As trocas afetivas e o sentimento de união pareceram favorecer o desenvolvimento do senso de potência nas crianças, permitindo a preservação da esperança e a projeção para a temporalidade de cura e crescimento, em consonância com o estudo de Grootenhuis e Last (2001).

Ela é amiga dele e ele é amigo dele [peixe-espada] e ele é amigo dele [pato]. Esse é outro peixe... Ele é amigo deles e fica amigo do tubarão... Ai todos ficam felizes para sempre... (Renata, 5 anos e 2 meses, Desenho-Estória 1)

Aí o pai da chapéu vermelho tem um negócio assim e o lobo mau fica com muito medo do pai da chapéu vermelho... (Renata, 5 anos e 2 meses, Desenho-Estória 2)

Ele não gosta de ficar sozinho... Com os amigos fica bem melhor... (Gabriel, 10 anos, DesenhoEstória 3) 
Ela [bruxa] vai tentar virar um dragão para não deixar que o príncipe pegue ela [Rapunzel], mas se ele conseguir matar a bruxa, ele consegue pegar a Rapunzel de primeira. (Valentim, 7 anos e 1 mês, Desenho-Estória 1)

De uma forma geral, as crianças evidenciaram percepção sobre a situação de ameaça e de gravidade, independente da idade ou da comunicação realizada sobre o processo de adoecimento. De formas singulares, cada uma se empenhou na busca de fortalecimento interno e de proteção por parte dos outros significados, a fim de enfrentar seus medos e transitar nas possibilidades existenciais saudáveis de ser no mundo (Forghieri, 1993).

\subsubsection{Aproximação com as vivências na relação criança-cuidador}

Nesse momento, foi proposta a atenção à relação estabelecida pela criança e seu cuidador, com vistas às interações e possíveis relações entre as compreensões singulares. Destacaram-se dois grandes temas: (1) vivência compartilhada ao longo do tratamento e (2) a questão da comunicação.

\subsubsection{Vivência compartilhada ao longo do tratamento}

O período de tratamento da recaída oncológica foi marcado pelo recomeço e suas incertezas. O contato com o conhecido do tratamento inicial se contrapunha ao desconhecido representado pela nova condição de doença e suas possibilidades de tratamento. Forghieri (1993) defendeu que, mesmo diante do "conhecido", a incerteza se revela enquanto abertura para o futuro, seus riscos e possibilidades, exigindo o confronto com as dificuldades e restrições, em busca da saúde existencial. Pais e crianças abordaram aspectos do sofrimento físico e emocional diante de procedimentos invasivos, das modalidades de tratamento e suas consequências (internação, restrição física, social e alimentar, desânimo, alopecia), com preocupações semelhantes ao primeiro tratamento (Araujo, 2006; Carvalho, 2002; Li et al., 2010). Apegavam-se às experiências do passado para a construção do sentido no presente, uma vez que o futuro se mostrava obscuro (Valle, 1997). No entanto, diante da recidiva, novos significados foram atribuídos às vivências, adequados à compreensão situacional e à temporalidade do passado, do presente e projeções ao futuro (Forghieri, 1993), sendo a incerteza e a ruptura das projeções para a temporalidade da cura constantes na expressão das díades estudadas, conforme apresentado nas análises anteriores. 
O tratamento judia demais, é muito desgastante, muito sofrimento... (Paula, 39 anos, mãe do Pablo)

Dá um desespero ver seu filho sem comer o dia todo! Quando ele diz que tem vontade de alguma coisa, eu dou mesmo! Trouxe lanche do Mc Donalds esse final de semana... Eu sei que não pode, que tem risco, mas ele já não pode tanta coisa! (Paula, 39 anos, mãe do Pablo)

O Gabriel ora todo dia antes de dormir, pede pra Deus ajudar para ele não perder a veia e não ter que ser furado de novo... Isso deixa ele muito nervoso, ele odeia e sofre muito! (Giovana, 34 anos, mãe do Gabriel)

Depois de fazer a quimioterapia, a defesa cai e sempre acontece alguma coisa: já teve boca em carne viva, dedo infeccionado, febre, e ai, tem que internar... Ele chora porque não quer ficar internado, é menino, né? Quer brincar com os amigos, ficar em casa... (Giovana, 34 anos, mãe do Gabriel)

A gente tinha que esquecer da gente, para dar força para ele... Tentava esmagar meus sentimentos e todo o sofrimento para não passar para ele, mas quando eu não conseguia, saía de perto dele para chorar... Eu não gosto de fazer isso na frente dele... (Giovana, 34 anos, mãe do Gabriel)

Mas nem eu saio daqui, fico só nesse quarto de hospital, sem videogame... Continuando... Ela não saía por nada, ela gostava de ficar no castelo, tinha lindas flores uma de cada cor da natureza... [E como ela se sente?] Triste, é uma tortura! (Gabriel, 10 anos, Desenho-Estória 2)

Então, teve tempos tranquilos, mas teve vez de eu achar que não ia levar a Renata pra casa... Porque de cada 8, só um escapa dessa infecção que ela teve.... A hospitalar, sabe? Até a médica falou "Pai, eu pensei que o Sr. ia sem a Renata... Foi grave, gravíssimo"... (Ricardo, 32 anos, pai da Renata)

Ele gritava muito, gritava, gritava mesmo, de desespero, e muitas vezes me culpava, que eu era a culpada de ele tá lá, tomando isso... (Vera, 33 anos, mãe do Valentim)

Ai depois que costurou o pé fica de repouso... Ai depois quando sarou, ele e pode brincar... [E a dor?] Passou... [E o que ele achou de ficar de repouso?] Nada bom... Não podia se mexer, não podia nada! Foi assim que eu fiquei... (Valentim, 7 anos e 1 mês, Desenho-Estória 4)

Perceber o sofrimento dos filhos pareceu trazer implicações para as vivências dos cuidadores, sugerindo dificuldades emocionais que mereceriam atenção profissional, não apenas pela preocupação com a saúde emocional familiar, mas também com suas ressonâncias na significação e lida infantis (Araujo, 2006; Campos et al., 2007; Hinds et al., 2002; Lopes \& Valle, 2001; Oliveira et al., 2005).

\subsubsection{A questão da comunicação}

Apesar dos indícios sobre os recursos infantis, conforme discutido anteriormente, a questão da comunicação à criança sobre seu diagnóstico e processo terapêutico se mostrou conflituosa. Enquanto os pais de Gabriel e Renata se posicionaram de forma natural, estabelecendo uma comunicação aberta com as crianças, a mãe de Valentim hesitou, e os pais de Pablo a recusaram. Mesmo diante do velamento ou da comunicação incompleta, as 
crianças demonstraram percepção dos sinais e sintomas presentes, bem como vivências de ameaça e modificações na dinâmica familiar, que pareceram remetê-los às semelhanças do primeiro tratamento oncológico.

A gente não quer contar, porque ele sofre por antecipação só por saber que é "quimioterapia" e a gente acha que ele sofreria muito de saber que a doença voltou, "vou tratar para quê se não deu certo na primeira vez?" (Paula, 39 anos, mãe do Pablo)

Eu não conseguiria contar que a doença voltou... O Paulo também acha... É muito sofrimento desnecessário... (Paula, 39 anos, mãe do Pablo)

Olha meu travesseiro, tá cheio de cabelo! Esse remédio deve ser muito forte! [Forte, Pablo? Faz que sim com a cabeça e aponta o travesseiro] É que eu tô com pancreatite, então preciso tomar remédio pra sarar... (Pablo, 7 anos e 6 meses, Desenho-Estória 1)

A gente não esconde nada dele, sabe? Até tentamos, risos, mas não dá... Ele é um menino muito esperto... (Giovana, 34 anos, mãe do Gabriel)

Mas nem eu saio daqui, fico só nesse quarto de hospital, sem videogame... Continuando... Ela não saía por nada, ela gostava de ficar no castelo, tinha lindas flores uma de cada cor da natureza... [E como ela se sente?] Triste, é uma tortura! (Gabriel, 10 anos, Desenho-Estória 2)

A médica explicou que voltou... Não sei se ela entende direito, mas falo que tem que fazer a rádio pra poder ir pra casa e ela colabora muito... (Ricardo, 32 anos, pai da Renata)

Aí o pai da chapéu vermelho tem um negócio assim e o lobo mau fica com muito medo do pai da chapéu vermelho... (Renata, 5 anos e 2 meses, Desenho-Estória 2)

No começo eu tinha um pouco de receio de dizer, assim olha, você tá fazendo um tratamento que você tem que tratar uma doença, então, tudo isso eu resguardava ele. Então a Dra. A. [psiquiatra] começou a conversar e falar para ele, mas no fundo eu não queria que ele soubesse... (Vera, 33 anos, mãe do Valentim)

Mas me abalava ouvir a voz dele falando "Eu faço um tratamento, eu tenho leucemia"... (Vera, 33 anos, mãe do Valentim)

Mas tem jeito de costurar... Já fez cirurgia? [Não] É fácil, eu já fiz cirurgia ... Eles abrem o pé, por exemplo aqui... A pessoa tem um tumor, né? Ai eles pegam, abrem o corpo da pessoa, aí tira aquele bichinho lá e joga fora... Ai eles veem naquele binóculo lá, como é? [Microscópio?] $\dot{E}$, o bichinho que tem... Ai eles pegam e costuram com agulha o que eles fizeram e aqui fica costurado... Aí tem que ficar de repouso um tempão de dias... [E depois, o que acontece?] Depois quando sara, some aquela cirurgia, ai pode brincar o tanto que você quiser... (Valentim, 7 anos e 1 mês, Desenho-Estória 4)

Tais posicionamentos diante da situação de ameaça pareceram interferir nas relações de confiança estabelecidas e na organização infantil para enfrentar seus medos. A comunicação revelou-se como favorecedora de um maior senso de segurança, em detrimento do intuito parental de proteção e atenuação do sofrimento. No mais, identificou-se nos pais um importante esforço no sentido de esconder seus sentimentos ou mesmo informações, com custos emocionais importantes. Além disso, cabe ressaltar que a comunicação interpessoal ocorre por meio de comunicações verbais, gestuais e atitudes. Dessa forma, favorecer uma comunicação clara, atenta aos aspectos do desenvolvimento infantil e emocional dos familiares, também no momento da recidiva, pode diminuir fantasias e auxiliar no 
enfrentamento infantil e no suporte parental. Nesse sentido, a equipe de saúde pode atuar como facilitadora dessa comunicação, ou no momento da comunicação ou na educação sobre as informações (Forghieri, 1993; Hildenbrand et al., 2011; Ministério da Saúde, 2010).

Foi interessante perceber que a forma como as crianças significaram as situações impostas pelo tratamento, bem como a recaída da doença em si, pareceram se relacionar com a compreensão do cuidador e com a comunicação realizada, de forma a construir suas próprias compreensões do mundo. Hinds et al. (2002), pensando a assistência em situações de recidiva em oncologia pediátrica, destacaram a relação entre essas compreensões singulares e reforçaram a necessidade do cuidado emocional, não apenas à criança, mas estendido aos cuidadores, a fim de favorecer a identificação e elaboração dos sentimentos experimentados. 


\section{CONSIDERAÇÕES FINAIS}

A proposta de investigar as vivências relativas ao período de recidiva envolveu a aproximação com os contextos familiares e com os itinerários terapêuticos das crianças participantes, o que ofereceu informações sobre aspectos da realidade de assistência ao câncer pediátrico no país. Sugeriram-se reflexões sobre aspectos relativos à qualidade do tratamento, implicações para o prognóstico e aspectos psicossociais, notadamente nas situações de deslocamento territorial para o cuidado em saúde. Os achados reforçaram a necessidade de práticas educativas e treinamentos, desde a atenção básica até a comunidade, para maior atenção aos sintomas e eficiência no acesso ao tratamento adequado (Ministério da Saúde, 2008).

A experiência da recidiva foi acompanhada por sentimentos de tristeza e frustração, diante da expectativa de cura frustrada e necessidade de recomeço. Os cuidadores-familiares significaram esse momento com a constatação da ausência de controle diante das ameaças percebidas, buscando a construção de novas possibilidades de cuidado. As crianças expressaram sentimentos de ameaça, o que pareceu impulsioná-las para a busca de proteção, principalmente no âmbito afetivo. Na análise das díades, percebeu-se o entrelaçamento entre as vivências compartilhadas e aspectos da comunicação estabelecida, o que reforçou a necessidade do acompanhamento psicológico não apenas às crianças, mas também aos cuidadores, com vistas à atenção integral e ao favorecimento da organização para o enfrentamento (Araujo, 2006; Campos et al., 2007; Hinds et al., 2002; Lopes \& Valle, 2001; Oliveira et al., 2005).

A fim de refletir sobre escolhas metodológicas no percurso do trabalho, torna-se relevante pontuar que os instrumentos selecionados mostraram-se favorecedores da expressão emocional, auxiliando no acesso às vivências dos cuidadores e das crianças. A recusa de duas mães diante da gravação de áudio propôs a reflexão sobre a dificuldade em abordar a temática e tornar público o sentimento, muitas vezes conflituoso, experimentado diante da recaída da doença e do reacender dos medos. Acolher o pedido das participantes e buscar outras estratégias para o registro favoreceu o estabelecimento da relação de confiança e a diminuição da ameaça, permitindo o encontro autêntico. As crianças mostraram-se familiarizadas com a proposta gráfica, superando a hesitação do contar histórias com tranquilidade.

Quanto aos critérios de inclusão e exclusão da amostra, em posse dos resultados, considera-se pertinente a exclusão de pacientes em fase de final de vida, por permitir maior homogeneidade da amostra estudada. Após uma releitura dos desenhos, com a informação 
sobre a sobrevivência ou falecimento da criança, não se encontraram sinais específicos de perda da vitalidade, maiores recursos de enfrentamento ou de temáticas que se destacassem do conjunto de produções. Já nos materiais excluídos da amostra, por situação de morte, percebeu-se um distanciamento da característica expressiva geral da amostra final. Nas crianças estudadas, a vivência de ameaça e a temática da morte, em geral, foram acompanhadas de bons recursos de expressão simbólica e enfrentamento que, em um espaço de escuta e expressão, acredita-se que possa favorecer o processo de elaboração das vivências emocionais infantis, com vistas à qualidade de vida (Castelo, 2003; Kóvacs, 1992).

Cada participante apresentou uma visão singular acerca do momento experimentado, condizente com sua forma de ser no mundo, relações estabelecidas e significados atribuídos às situações em questão. Assim, as ressonâncias psicológicas do diagnóstico da recidiva não foram dadas a priori, mas nos sentidos construídos na medida em que as crianças se relacionavam com o mundo, transitando em seu mundo próprio, com o outro e com o mundo circundante, de maneira a se aproximar do conhecimento de si mesmas (Forghieri, 1993).

Os achados ofereceram subsídios para a reflexão sobre o papel da equipe de saúde como mediadora da relação criança-cuidador-recidiva. A comunicação, amplamente discutida em contextos de saúde, quando realizada de forma clara e condizente com aspectos do desenvolvimento infantil e atenta aos aspectos emocionais que permeiam o contexto familiar, mostrou-se favorecedora da organização familiar para o enfrentamento e significação do processo de adoecimento (Espíndula \& Valle, 2002; Hockenberry-Eaton et al., 1995; Mu et al., 2001). Além disso, a apropriação das informações e a relação de confiança com a equipe e a instituição de saúde também se constituíram como recursos para ressignificar as dificuldades e preocupações, singulares e compartilhadas. Diante das incertezas e busca de esperança, tais preocupações e responsabilidades encontram-se não apenas no diagnóstico de recaída ou na progressão, mas também na apresentação e na discussão com as famílias sobre possibilidades terapêuticas, investigacionais (pesquisa clínica) e ações de cuidados paliativos, de forma a favorecer o cuidado ao paciente e a seu processo de tomadas de decisões.

Reconhecer as limitações e o sofrimento envolvido na experiência da recaída oncológica mostrou-se essencial para a organização para agir e, desta forma, abrir-se para as possibilidades do ser e de significar a existência (Forghieri, 1993; Valle, 1997). 


\section{REFERÊNCIAS ${ }^{5}$}

Al-Gamal, E., \& Long, T. (2010). Anticipatory grieving among parents living with a child with cancer. Journal of advanced nursing, 66(9), 1980-90. doi:10.1111/j.13652648.2010.05381.x

Alves, D. F. S., Guirardello, E. B., \& Kurashima, A. Y. (2013). Stress related to care: the impact of childhood cancer on the lives of parents. Revista Latino-Americana de Enfermagem, 21(1), 356-362. doi:10.1590/S0104-11692013000100010

Amazonas, M. C. L. A., \& Braga, M. G. R. (2006). Reflexões acerca das novas formas de parentalidade e suas possíveis vicissitudes culturais e subjetivas. Ágora: Estudos em Teoria Psicanalítica, 9(2), 177-191. doi:10.1590/S1516-14982006000200002

Ancona-Lopez, S. (1997). Análise segundo outros pressupostos teóricos: Abordagem fenomenológico-existencial. In W. Trinca (Ed.), Formas de investigação clínica em psicologia: procedimento de desenhos-estórias e procedimento de desenhos de de família com estórias (pp. 131-133). São Paulo: Vetor.

Andersen, B. L., Carpenter, K. M., Yang, H. C., \& Shapiro, C. L. (2007). Sexual well-being among partnered women with breast cancer recurrence. Journal of clinical oncology: official journal of the American Society of Clinical Oncology, 25(21), 3151-7. doi:10.1200/JCO.2006.09.6958

Araujo, T. C. C. F. (2006). Câncer Infantil: intervenção, formação e pesquisa em psicooncologia pediátrica. Psicologia Hospitalar, 4(1), 1-12. Retrieved from http://pepsic.bvsalud.org/scielo.php?script=sci_arttext\&pid=S1677$74092006000100005 \& \operatorname{lng}=$ pt\&nrm $=$ iso \&tlng $=$ pt

Arrais, A. R., \& Araujo, T. C. C. F. (1999). Recidiva X Cura: A vivência paradoxal da sobrevivência ao câncer na infância. Revista Brasileira de Cancerologia, 45(3), 15-22.

Augras, M. (1986). O ser da compreensão: fenomenologia da situação de psicodiagnóstico. (p. 96). Petrópolis: Vozes.

Barbosa, C. G., Neme, C. M. B., \& Melchiori, L. E. (2011). A Família e o Indivíduo no curso vital: compreensão Trigeracional sobre a morte e o morrer. Revista Mal-estar e Subjetividade, 11(3), 1055-1094.

Beltrão, M. R. L. R., Vasconcelos, M. G. L., Pontes, C. M., \& Albuquerque, M. C. (2007). Câncer infantil: percepções maternas e estratégias de enfrentamento frente ao diagnóstico. Jornal de Pediatria, 83(6), 562-566. doi:10.1590/S002175572007000800014

Bodgan, R. C., \& Biklen, S. K. (1997). Investigação qualitativa em educação: uma introdução à teoria e aos métodos. (p. 335). Porto: Porto.

Bomfim, I. H. F. B., \& Barbieri, V. (2009). Subvirtiendo la evaluación psicológica: el empleo del procedimiento de dibujos-historias en un paciente con tartamudez. Psicol. teor. prát, 11(2), 17-37. Retrieved from http://pepsic.bvsalud.org/scielo.php?script=sci_arttext\&pid=S1516-36872009000200003

Bonner, M. J., Hardy, K. K., Willard, V. W., \& Hutchinson, K. C. (2007). Brief report: psychosocial functioning of fathers as primary caregivers of pediatric oncology patients. Journal of pediatric psychology, 32(7), 851-6. doi:10.1093/jpepsy/jsm011

Bruce, M., Gumley, D., Isham, L., Fearon, P., \& Phipps, K. (2011). Post-traumatic stress symptoms in childhood brain tumour survivors and their parents. Child: care, health and development, 37(2), 244-51. doi:10.1111/j.1365-2214.2010.01164.x

\footnotetext{
${ }^{5}$ De acordo com o estilo APA - American Psychological Association.
} 
Burón, R. R., Rodríguez, J. A. P., Linares, V. R., López, L. J. G., Gonzáles, A. E. M., \& Guadalupe, L. A. O. (2008). Psicología y cancer. Suma Psicologica, 15(1), 171-198.

Campos, E. M. P. (2007). Infância e Família. In J. M. Filho \& M. Burd (Eds.), Doenca E Familia (p. 412). Casa do Psicólogo. Retrieved from http://books.google.com/books?id=ZUv0a4gH3B0C\&pgis=1

Campos, E. M. P. (2010). A psico-oncologia. Boletim Academia Paulista de Psicologia, 30(79), 440-449.

Campos, E. M. P., Rodrigues, A. L., Machado, P., \& Alvarez, M. (2007). Intervenção em grupo: experiência com mães de crianças com câncer. Psicologia em Estudo, 12(3), 635640. doi:10.1590/S1413-73722007000300021

Cardoso, F. T. (2007). Câncer infantil: aspectos emocionais e atuação do psicólogo. Revista da $\quad$ SBPH, $10(1), \quad 25-52 . \quad$ Retrieved from http://pepsic.bvsalud.org/scielo.php?script=sci_arttext\&pid=S151608582007000100004\&lng=pt\&nrm=iso\&tlng=pt

Carvalho, M. M. (2002). Psico-oncologia: história, características e desafios. Psicologia USP, 13(1), 151-166. doi:10.1590/S0103-65642002000100008

Castelo, M. T. P. (2003). Especificidades da Comunicação no Trabalho Clínico com Crianças. Universidade de São Paulo.

Castro, E. H. B. (2010). Child cancer experince: family, personal and social repercussions. Rev. mal-estar subj, 10(3), 971-994. Retrieved from http://pepsic.bvsalud.org/scielo.php?script=sci_arttext\&pid=S1518-61482010000300013

Castro, E. K., \& Piccinini, C. A. (2002). Implicações da doença orgânica crônica na infância para as relações familiares: algumas questões teóricas. Psicologia: Reflexão e Crítica, 15(3), 625-635. doi:10.1590/S0102-79722002000300016

Centro Infantil Boldrini. (2010). Video institucional. Retrieved from http://www.boldrini.org.br/site/inc/video.htm

Chao, C. C., Chen, S. H., Wang, C. Y., Wu, Y. C., \& Yeh, C. H. (2003). Psychosocial adjustment among pediatric cancer patients and their parents. Psychiatry and clinical neurosciences, 57(1), 75-81. doi:10.1046/j.1440-1819.2003.01082.x

Conselho Federal de Psicologia. Resolução - CFP no 016/2000 (2000).Dispõe sobre a realização de pesquisa em Psicologia com seres humanos. Distrito Federal: Conselho Federeal de Psicologia.

Conselho Nacional de Saúde. Resolução no 196/96 (1996).Aprovar as seguintes diretrizes e normas regulamentadoras de pesquisas envolvendo seres humanos. Distrito Federal: Conselho Nacional de Saúde.

Correia, D. S., Oliveira, L. F. G., \& Vieira, M. J. (2003). Representações do adoecer por crianças de 5 a 12 anos de idade internas no Hospital Dr. Alberto Antunes UFAL. Pediatr. mod, 39, 412-416.

Costa Junior, Á. L. (1999). Psico-Oncologia e manejo de procedimentos invasivos em oncologia pediátrica: uma revisão de literatura. Psicologia: Reflexão e Crítica, 12(1), 107-118. doi:10.1590/S0102-79721999000100007

Costa Junior, Á. L. (2001). O desenvolvimento da psico-oncologia: implicações para a pesquisa e intervenção profissional em saúde. Psicologia: ciência e profissão, 21(2), 3643. Retrieved from http://pepsic.bvsalud.org/scielo.php?script=sci_arttext\&pid=S141498932001000200005\&lng=pt\&nrm=iso\&tlng=pt

Crossley, M. (2007). Evaluating qualitative research. In J. M. Addington-Hall, E. Bruera, I. J. Higginson, \& S. Payne (Eds.), Research methods in Palliative Care (pp. 181-189). New York: Oxford. 
Cupertino, C. M. B. (1995). O psicodiagnóstico fenomenológico e os desencontros possíveis. In M. Ancona-Lopez (Ed.), Psicodiagnóstico: processo interventivo (pp. 135-178). São Paulo: Cortez.

De Graves, S., \& Aranda, S. (2008). Living with hope and fear--the uncertainty of childhood cancer after relapse. Cancer nursing, 31(4), 292-301. doi:10.1097/01.NCC.0000305745.41582.73

Dunn, M. J., Rodriguez, E. M., Barnwell, A. S., Grossenbacher, J. C., Vannatta, K., Gerhardt, C. A., \& Compas, B. E. (2012). Posttraumatic stress symptoms in parents of children with cancer within six months of diagnosis. Health Psychology, 31(2), 176-185. doi: $10.1037 / \mathrm{a} 0025545$

Durham, E. R. (1983). Família e reprodução humana. In E. R. Durham (Ed.), Perspectivas antropológicas da mulher 3 (pp. 13-44). Rio de Janeiro: Zahar.

Durham, E. R. (1984). Texto II. In A. A. Arantes (Ed.), Produzindo o passado: estratégias de construção do patrimônio cultural (pp. 23-58). São Paulo: Brasiliense.

Espíndula, J. A. (2001a). Vivências de mães em situação de recidiva de câncer. Universidade de São Paulo.

Espíndula, J. A. (2001b). Vivências de mães em situação de recidiva de câncer. In E. R. M. Valle (Ed.), Psico-oncologia pediátrica (pp. 129-179). São Paulo: Casa do Psicólogo.

Espíndula, J. A., \& Valle, E. R. M. (2002). Experiência materna diante da iminência de morte do filho com recidiva de câncer. Pediatr. mod, 38(5), 188-194. Retrieved from http://www.moreirajr.com.br/revistas.asp? fase=r003\&id_materia $=1916$

Essig, S., von der Weid, N. X., Strippoli, M.-P. F., Rebholz, C. E., Michel, G., Rueegg, C. S., Kuehni, C. E. (2012). Health-related quality of life in long-term survivors of relapsed childhood acute lymphoblastic leukemia. (A. M. Moormann, Ed.)PloS one, 7(5), e38015. doi:10.1371/journal.pone.0038015

Fontanella, B. J. B., Luchesi, B. M., Saidel, M. G. B., Ricas, J., Turato, E. R., \& Melo, D. G. (2011). Amostragem em pesquisas qualitativas: proposta de procedimentos para constatar saturação teórica. Cadernos de Saúde Pública, 27(2), 388-394. doi:10.1590/S0102-311X2011000200020

Forghieri, Y. C. (1993). Psicologia fenomenológica: Fundamentos, métodos e pesquisas. São Paulo: Pioneira.

Françoso, L. P. C. (2001). Assistência psicológica à criança com câncer - os grupos de apoio. In E. R. M. Valle (Ed.), Psico-oncologia pediátrica (pp. 129-179). São Paulo: Casa do Psicólogo.

Gibbins, J., Steinhardt, K., \& Beinart, H. (2012). A systematic review of qualitative studies exploring the experience of parents whose child is diagnosed and treated for cancer. Journal of pediatric oncology nursing : official journal of the Association of Pediatric Oncology Nurses, 29(5), 253-71. doi:10.1177/1043454212452791

Gilligan, C. (1982). O lugar da Mulher na Vida do Homem. In Uma voz diferente: Psicologia da diferença entre homens e mulheres da infância à idade adulta (pp. 15-36). Rio de Janeiro: Rosa dos Tempos.

Gomes, W. B., \& Castro, T. G. de. (2010). Clínica Fenomenológica:Do Método de Pesquisa para a Prática Psicoterapêutica. Psicologia: Teoria e Pesquisa. Retrieved from https://revistaptp.unb.br/index.php/ptp/article/view/481

Goto, T. A. (2008). Introdução à psicologia fenomenológica: a nova psicologia de Edmund Husserl (p. 254). São Paulo: Paulus.

Grootenhuis, M. A., \& Last, B. F. (2001). Children with cancer with different survival perspectives: defensiveness, control strategies, and psychological adjustment. Psychooncology, 10(4), 305-14. $\quad$ Retrieved from http://www.ncbi.nlm.nih.gov/pubmed/11462229 
Haddy, R. I., \& Haddy, T. B. (2010). Lifetime follow-up care after childhood cancer. Journal of the American Board of Family Medicine: JABFM, 23(5), 647-54. doi:10.3122/jabfm.2010.05.100031

Hildenbrand, A. K., Clawson, K. J., Alderfer, M. A., \& Marsac, M. L. (2011). Coping with pediatric cancer: strategies employed by children and their parents to manage cancerrelated stressors during treatment. Journal of pediatric oncology nursing: official journal of the Association of Pediatric Oncology Nurses, 28(6), 344-54. doi:10.1177/1043454211430823

Hinds, P. S., Birenbaum, L. K., Clarke-Steffen, L., Quargnenti, A., Kreissman, S., Kazak, A., Wilimas, J. (1996). Coming to terms: parents' response to a first cancer recurrence in their child. Nursing research, 45(3), 148-53. Retrieved from http://www.ncbi.nlm.nih.gov/pubmed/8637795

Hinds, P. S., Birenbaum, L. K., Pedrosa, A. M., \& Pedrosa, F. (2002). Guidelines for the recurrence of pediatric cancer. Seminars in oncology nursing, 18(1), 50-9. Retrieved from http://www.ncbi.nlm.nih.gov/pubmed/11878040

Hockenberry-Eaton, M., Dilorio, C., \& Kemp, V. (1995). The relationship of illness longevity and relapse with self-perception, cancer stressors, anxiety, and coping strategies in children with cancer. Journal of pediatric oncology nursing: official journal of the Association of Pediatric Oncology Nurses, 12(2), 71-9. Retrieved from http://www.ncbi.nlm.nih.gov/pubmed/7612200

Hospital do Câncer. (2003). A criança com câncer: O que devemos saber? São Paulo: Comunique.

Ingleton, C., \& Davies, S. (2007). Mixed methods for evaluation research. In J. M. Addington-Hall, E. Bruera, I. J. Higginson, \& S. Payne (Eds.), Research methods in Palliative Care (pp. 192-209). New York: Oxford.

Klassen, A. F., Klaassen, R., Dix, D., Pritchard, S., Yanofsky, R., O’Donnell, M., Sung, L. (2008). Impact of caring for a child with cancer on parents' health-related quality of life. Journal of clinical oncology: official journal of the American Society of Clinical Oncology, 26(36), 5884-9. doi:10.1200/JCO.2007.15.2835

Klassen, A., Raina, P., Reineking, S., Dix, D., Pritchard, S., \& O’Donnell, M. (2007). Developing a literature base to understand the caregiving experience of parents of children with cancer: a systematic review of factors related to parental health and wellbeing. Supportive care in cancer: official journal of the Multinational Association of Supportive Care in Cancer, 15(7), 807-18. doi:10.1007/s00520-007-0243-x

Kohlsdorf, M. (2010). Aspectos psicossociais no câncer pediátrico: estudo sobre literatura brasileira publicada entre 2000 e 2009 DOI 10.5752/P.1678-9563.2010v16n2p271. Psicologia em Revista, 16(2), 271-294. doi:10.5752/P.1678-9563.2010v16n2p271

Kohlsdorf, M., \& Costa Junior, Á. L. (2011). Coping strategies and caregiver's anxiety in pediatric oncohematology. Psicologia: Reflexão e Crítica, 24(2), 272-280. doi:10.1590/S0102-79722011000200008

Kohlsdorf, M., \& Costa Junior, Á. L. (2012). Impacto psicossocial do câncer pediátrico para pais: revisão da literatura. Paidéia (Ribeirão Preto), 22(51), 119-129. Retrieved from http://www.scielo.br/scielo.php?script=sci_arttext\&pid=S0103-863X2012000100014

Kohlsdorf, M., \& Costa Junior, Á. L. da. (2008). Estratégias de enfrentamento de pais de crianças em tratamento de câncer. Estudos de Psicologia (Campinas), 25(3), 417-429. doi:10.1590/S0103-166X2008000300010

Kóvacs, M. J. (1992). Morte e desenvolvimento humano. São Paulo: Casa do Psicólogo.

Kubler-Ross. (1998). Sobre a morte e o morrer. São Paulo: Martins Fontes. 
Lavee, Y., \& Mey-Dan, M. (2003). Patterns of change in marital relationships among parents of children with cancer. Health \& social work, 28(4), 255-63. Retrieved from http://www.ncbi.nlm.nih.gov/pubmed/14679704

Lei 8.069/90 (1990). Dispõe sobre as condições para a promoção, proteção e recuperação da saúde, a organização e o funcionamento dos serviços correspondentes e dá outras providências. Retrieved from http://www.planalto.gov.br/ccivil_03/Leis/L8069.htm

Lemos, F. A., Lima, R. A. G. de, \& Mello, D. F. de. (2004). Assistência à criança e ao adolescente com câncer: a fase da quimioterapia intratecal. Revista Latino-Americana de Enfermagem, 12(3), 485-493. doi:10.1590/S0104-11692004000300006

Li, H. C. W., Chung, O. K. J., \& Chiu, S. Y. (2010). The impact of cancer on children's physical, emotional, and psychosocial well-being. Cancer nursing, 33(1), 47-54. doi:10.1097/NCC.0b013e3181aaf0fa

Lin, L., Yeh, C.-H., \& Mishel, M. H. (2010). Evaluation of a conceptual model based on Mishel's theories of uncertainty in illness in a sample of Taiwanese parents of children with cancer: a cross-sectional questionnaire survey. International journal of nursing studies, 47(12), 1510-24. doi:10.1016/j.ijnurstu.2010.05.009

Long, K. A., \& Marsland, A. L. (2011). Family adjustment to childhood cancer: a systematic review. Clinical child and family psychology review, 14(1), 57-88. doi:10.1007/s10567010-0082-z

Lopes, D. P. L., \& Valle, E. R. M. (2001). A organização familiar e o acontecer do tratamento da criança com câncer. In Psico-oncologia Pediátrica (pp. 13-74). São Paulo: Casa do Psicólogo.

Malta, J. D. S., Schall, V. T., Reis, J. do C., \& Modena, C. M. (2008). Quando falar é difícil: a narrativa de crianças com câncer. Pediatr. mod, 45(5). Retrieved from http://www.moreirajr.com.br/revistas.asp?fase=r003\&id_materia $=4095$

McKenzie, S. E., \& Curle, C. (2012). "The end of treatment is not the end": parents' experiences of their child's transition from treatment for childhood cancer. Psychooncology, 21(6), 647-54. doi:10.1002/pon.1953

Mendes, K. D. S., Silveira, R. C. de C. P., \& Galvão, C. M. (2008). Revisión integradora: método de investigación para la incorporación de evidencias en la salud y la enfermería. Texto \& contexto enferm, 17(4), 758-764. Retrieved from http://www.scielo.br/scielo.php?script=sci arttext\&pid=S0104-07072008000400018

Menezes, C. N. B., Passareli, P. M., Drude, F. S., Santos, M. A., \& Valle, E. R. M. (2007). Câncer infantil: organização familiar e doença. Revista Mal Estar e Subjetividade, 7(1), 191-210.

Retrieved

from http://pepsic.bvsalud.org/scielo.php?script=sci_arttext\&pid=S1518$61482007000100011 \& \operatorname{lng}=\mathrm{pt} \& \mathrm{nrm}=\mathrm{iso} \& \mathrm{t} \operatorname{lng}=\mathrm{pt}$

Minayo, M. C. S. (2008). O Desafio do Conhecimento - Pesquisa Qualitativa em Saúde. São Paulo: Hucitec.

Ministério da Saúde. Portaria 3.535. , Pub. L. No. nº 196-E, Seção 1 (1998). Brasil: Diário Oficial da União.

Ministério da Saúde. (2008). Câncer da criança e adolescente no Brasil: dados dos registros de base populacional e de mortalidade. Rio de Janeiro: Ministério da Saúde.

Ministério da Saúde. (2010). Comunicação de notícias dificeis: compartilhando desafiosna atenção à saúde (p. 208). Rio de Janeiro: Ministério da Saúde.

Ministério da Saúde. (2011). Estimativas 2012: Incidência de Câncer no Brasil. Rio de Janeiro: Ministério da Saúde.

Montoya-Juárez, R., García-Caro, M. P., Calderón, C. C., Rio-Valle, J. S., Sorroche-Navarro, C., \& Quintana, F. C. (2012). Sufrimiento en infantes con enfermedad terminal: 
perspectiva de padres y profesionales. Revista da Escola de Enfermagem da USP, 46(6), 1300-1305. doi:10.1590/S0080-62342012000600003

Moreira, P. L., \& Angelo, M. (2008). Becoming a mother of a child with cancer: building motherhood. Revista Latino-Americana de Enfermagem, 16(3), 355-361. doi:10.1590/S0104-11692008000300004

Motta, A. B., Enumo, S. R. F., \& Ferrao, E. S. (2006). Avaliação das estratégias de enfrentamento da hospitalização em crianças com câncer. In M. B. M. Linhares, M. A. Crepaldi, \& G. B. Perosa (Eds.), Temas em Psicologia (pp. 191-217). São Paulo: Casa do Psicólogo.

Mu, P. F., Ma, F. C., Ku, S. M., Shu, H. Q., Hwang, B., \& Kuo, B. I. (2001). Families of Chinese children with malignancy: the factors impact on mother's anxiety. Journal of pediatric nursing, 16(4), 287-95. doi:10.1053/jpdn.2000.25325

Munhóz, M. L. P. A. (1995). A criança participante do psicodiagnóstico infantil grupal. In M. Ancona-Lopez (Ed.), Psicodiagnóstico: processo interventivo (pp. 179-195). São Paulo: Cortez.

National Cancer Institute. (n.d.). Dictionary of cancer terms. Retrieved March 09, 2013, from www.cancer.org

Oliveira, É. A., Santos, M. A., \& Mastropietro, A. P. (2010). Apoio psicológico na terminalidade: ensinamentos para a vida. Psicologia em Estudo, 15(2), 235-244. doi:10.1590/S1413-73722010000200002

Oliveira, É. A., Voltarelli, J. C., Santos, M. A., \& Mastropietro, A. P. (2005). Intervenção junto à família do paciente com alto risco de morte. Medicina (Ribeirão Preto), 38(1), 63-68.

Oliveira-Cardoso, É. A., \& Santos, M. A. (2008). Reorganização familiar após a enfermidade fatal de um filho: o pai como cuidador. Revista da SPAGESP, 9(2), 39-44. Retrieved from http://pepsic.bvsalud.org/scielo.php?script=sci_arttext\&pid=S1677$29702008000200007 \& \operatorname{lng}=\mathrm{pt} \& n \mathrm{~mm}=\mathrm{iso} \& \operatorname{lng}=\mathrm{pt}$

Paiva, G. J. de. (2007). Religião, enfrentamento e cura: perspectivas psicológicas. Estudos de Psicologia (Campinas), 24(1), 99-104. doi:10.1590/S0103-166X2007000100011

Parkes, C. M. (1998). Luto: Estudos sobre a perda na vida adulta. São Paulo: Summus.

Payne, S. (2007). Qualitative methods os data collection and analysis. In J. M. AddingtonHall, E. Bruera, I. J. Higginson, \& S. Payne (Eds.), Research methods in Palliative Care (pp. 139-160). New York: Oxford.

Pedro, I. C. da S., Galvão, C. M., Rocha, S. M. M., \& Nascimento, L. C. (2008). Social support and families of children with cancer: an integrative review. Revista latinoamericana de enfermagem, 16(3), 477-83. Retrieved from http://www.ncbi.nlm.nih.gov/pubmed/18695825

Peres, R. S., \& Santos, M. A. dos. (2005). General considerations and practical orientations regarding the use of case studies in scientific research in psychology. Interações estud. pesqui. psicol, 10(20), 109-126. Retrieved from http://pepsic.bvsalud.org/scielo.php?script=sci_arttext\&pid=S1413$29072005000200008 \& \operatorname{lng}=$ pt\&nrm=iso

Pérez Cárdenas, C., \& Rodríguez Herrera, F. (2006). Diagnóstico oncológico: reacción emocional y comportamiento familiar asumido. Psicologia para América Latina, (5). Retrieved from http://pepsic.bvsalud.org/scielo.php?script=sci_arttext\&pid=S1870$350 X 2006000100004 \& \operatorname{lng}=\mathrm{pt} \& \mathrm{nrm}=\mathrm{iso} \& \mathrm{t} \operatorname{lng}=\mathrm{pt}$

Perina, E. M. (2005). Breve histórico da psiconcologia pediátrica no Brasil. In E. M. Perina \& N. A. C. Nucci (Eds.), As dimensões do cuidar em psiconcologia pediátrica (pp. 19-25). Campinas: Livro Pleno. 
Perina, E. M. (1992). Estudo das relações interpessoais da criança com câncer nas fases terminais. Universidade de São Paulo.

Pompeo, D. A., Galvão, C. M., \& Rossi, L. A. (2009). Revisão integrativa: etapa inicial do processo de validação de diagnóstico de enfermagem. Acta Paulista de Enfermagem, 22(4), 434-438. Retrieved from http://www.redalyc.org/resumen.oa?id=307023838014

Prchal, A., Graf, A., Bergstraesser, E., \& Landolt, M. A. (2012). A two-session psychological intervention for siblings of pediatric cancer patients: a randomized controlled pilot trial. Child and adolescent psychiatry and mental health, 6(1), 3. doi:10.1186/1753-2000-6-3

Rodrigues, K. E., \& Camargo, B. de. (2003). Early diagnosis of childhood cancer: a team responsibility. Rev. Assoc. Med. Bras. (1992), 49(1), 29-34. Retrieved from $\mathrm{http}: / /$ www.scielo.br/scielo.php?script=sci_arttext\&pid=S0104$42302003000100030 \& \operatorname{lng}=$ pt\&nrm $=$ iso

Romanelli, G. (2003). Paternidade em famílias de camadas médias. Estudos e Pesquisas em Psicologia, 3(2), 79-96. $\quad$ Retrieved from http://pepsic.bvsalud.org/scielo.php?script=sci_arttext\&pid=S180842812003000200006\&lng $=$ pt\&nrm $=$ iso\&tlng $=$ pt

Romano, B. W. (2007). Princípios para a prática da psicologia clínica em hospitais. São Paulo: Casa do Psicólogo.

Safra, G. (1984). O procedimento de desenhos e estórias. In W. Trinca (Ed.), Diagnóstico psicológico: A prática clínica (pp. 55-57). São Paulo: EPU.

Scott, R. P. (2001). Famílias sem casais e a diversidade conjugal no Brasil. Interseções $-R$. De Est. Interdisc., 3(2), 93-112.

Shim, E.-J., Shin, Y.-W., Oh, D.-Y., \& Hahm, B.-J. (2010). Increased fear of progression in cancer patients with recurrence. General hospital psychiatry, 32(2), 169-75. doi:10.1016/j.genhosppsych.2009.11.017

Silva, G. M., Teles, S. S., \& Valle, E. R. M. (2005). Estudo sobre as publicações brasileiras relacionadas a aspectos psicossociais do câncer infantil - período de 1998 a 2004. Revista Brasileira de Cancerologia, 51(3), 253-261.

Stake, R. E. (2000). Case study. In N. K. Denzin \& Y. S. Lincoln (Eds.), Handbook of qualitative research (pp. 236-247). Thousand Oaks: Sage.

Staliano, P., \& Araújo, T. C. C. F. (2009). Estudos e pesquisas em Psico-Oncologia: levantamento realizado no Portal PePSIC. Revista da SBPH, 12(2), 54-68. Retrieved from http://pepsic.bvsalud.org/scielo.php?script=sci_arttext\&pid=S151608582009000200006\&lng=pt\&nrm=iso\&tlng=pt

Steffen, B. C., \& Castoldi, L. (2006). Sobrevivendo à tempestade: a influência do tratamento oncológico de um filho na dinâmica conjugal. Psicologia: Ciência e Profissão, 26(3), 406-425. doi:10.1590/S1414-98932006000300006

Sung, L., Klaassen, R. J., Dix, D., Pritchard, S., Yanofsky, R., Ethier, M. C., \& Klassen, A. (2009). Parental optimism in poor prognosis pediatric cancers. Psycho-oncology, 18(7), 783-8. doi:10.1002/pon.1490

Teles, S. S., \& Valle, E. R. M. (2009). Adulto sobrevivente de câncer infantil: uma revisão bibliográfica. Psicologia em Estudo, 14(2), 355-363. doi:10.1590/S141373722009000200017

Thorne, B. (1992). A domestic refuge for whom? The discovery of housework. In B. Thorne \& M. Yalom (Eds.), Rethinking the family: some feminist questions (pp. 17-30). Boston: Northeasten University Press.

Trinca, W. (1997). Formas de investigação clínica em psicologia: Procedimento de desenhosestórias e procedimento de desenhos de família com estórias. São Paulo: Vetor.

Triviños, A. N. S. (1992). Introdução à pesquisa em ciências sociais: A pesquisa qualitativa em educação. São Paulo: Atlas. 
Turato, E. R. (2003). Tratado de metodologia da pesquisa clínico- qualitativa: Construção teórico-epistemológica, discussão comparada e aplicação nas áreas da saúde e humanas. Petrópolis: Vozes.

Valle, E. R. M. (1994). Vivência da Familia da Crianca Com Câncer. In E. R. M. Valle (Ed.), Introdução à Psicologia (pp. 219-242). Campinas: Psy.

Valle, E. R. M. (1997). Câncer infantil: Compreender e agir. Campinas: Psy.

Vivar, C. G., Canga, N., Canga, A. D., \& Arantzamendi, M. (2009). The psychosocial impact of recurrence on cancer survivors and family members: a narrative review. Journal of advanced nursing, 65(4), 724-36. doi:10.1111/j.1365-2648.2008.04939.x

Vivar, C. G., Whyte, D. A., \& McQueen, A. (2010). "Again": the impact of recurrence on survivors of cancer and family members. Journal of clinical nursing, 19(13-14), 204856. doi:10.1111/j.1365-2702.2009.03145.x

Yang, H. C., Thornton, L. M., Shapiro, C. L., \& Andersen, B. L. (2008). Surviving recurrence: psychological and quality-of-life recovery. Cancer, 112(5), 1178-87. doi: $10.1002 /$ cncr. 23272

Yeh, C. H. (2003). Dynamic coping behaviors and process of parental response to child's cancer. Applied nursing research: ANR, 16(4), 245-55. Retrieved from http://www.ncbi.nlm.nih.gov/pubmed/14608558 

ANEXO A - Aprovação do projeto pelo Comitê de Ética em Pesquisa

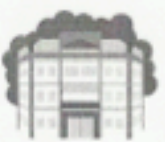

Centro Infontil

Boldrini

Ilma. Sra.

Marina Noronha Ferraz de Arruda

Prezada Senhora,

Informamos que seu projeto intitulado "A CRIANÇA EM RECIDIVA DE CÂNCER PEDIÁtrico: VIVÊNCIAS, DESENHOS E ESTÓRIAS" foi aprovado pelo Comitê de Ética em Pesquisa do Centro Infantil Boldrini (CEP/Boldrini) em reunião de 28/01/2011.

Informamos que a cada 6 meses, deverá ser apresentado um relatório parcial sobre o andamento da pesquisa em questăo (formulário: acompanhamento das pesquisas; disponivel no site: www.boldrini.org.br ou no L: público/ CECI CEP Formulários) ao Comitê de Ética em Pesquisa do Centro Infantil Boldrini (CEP/Boldrini).

Solicitamos que, após a concluş̋o do estudo, o mesmo seja encaminhado à Secretaria do CEP/Boldrini e apresentado aos profissionais do Centro Infantil Boldrini.

Colocamo-nos à disposiçăo para maiores esclarecimentos.

Cordialmente,

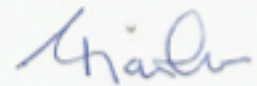

Prof. Dr. Flávio César de Sá

Vice-Coordenador do CEP/Boldrini 



\section{APÊNDICE A - Roteiro de Entrevista Semiestruturada}

Nome do paciente:

Idade:

Nome do familiar entrevistado:

Idade:

Constituição familiar:

\begin{tabular}{|c|c|c|c|c|c|}
\hline Grau de parentesco & Idade & Escolaridade & Profissão & Renda & Religião \\
\hline & & & & & \\
\hline & & & & & \\
\hline & & & & & \\
\hline & & & & & \\
\hline & & & & & \\
\hline & & & & & \\
\hline
\end{tabular}

1) Fale sobre o desenvolvimento de seu/sua filho(a), desde seu nascimento até hoje.

2) Conte-me como foi o processo de adoecimento e tratamento de seu/sua filho(a).

[Esperar que surja, espontaneamente, na fala do cuidador a questão da recidiva do câncer infantil e explorar as suas reações, bem como dos demais familiares, desde que tomaram conhecimento do fato. Como está a vida familiar desde então? Explorar como a família tem lidado com a questão e como tem se reorganizado para fazer frente às necessidades do tratamento.]

3) Como são o relacionamento e a rotina familiar?

[O que aconteceu, em termos dos relacionamentos, desde que souberam da recaída da doença?] 



\section{APÊNDICE B - Termo de Consentimento Livre e Esclarecido}

Centro Infantil

Boldrini

\section{Dados de Identificação do Sujeito da Pesquisa ou Responsável Legal}

Nome do Paciente:

Documento de Identidade $\mathrm{n}^{\mathrm{o}}$ : Sexo: $\square \mathrm{M}$ $\square \mathrm{F}$

Data nascimento: I 1

Endereço: $n^{o}$ Apto:

Bairro: Cidade: Estado:

CEP: Telefone:

Responsável Legal:

Natureza (grau de parentesco, tutor, curador, etc.):

Documento de Identidade $\mathrm{n}^{\mathrm{o}}$ : Sexo: $\square \mathrm{M}$ $\square \mathrm{F}$

Data nascimento: /

Endereço: $\mathrm{n}^{\mathrm{o}}$ Apto.:

Bairro: Cidade: Estado:

Dados sobre a Pesquisa Científica

Título do Projeto de Pesquisa: "A criança em recidiva de câncer pediátrico: Vivências, desenhos e estórias".

Pesquisadora: Marina Noronha Ferraz de Arruda - Tel: (19) 8114-7745 - e-mail: arruda.mnf@gmail.com

Cargo/Função: Psicóloga / Aluna do curso de especialização

Orientadora da Pesquisa: Profa. Dra. Elisa Maria Perina - Tel.: (19) 3787-5012 - email: perina@,boldrini.org.br

Unidades do Centro Infantil Boldrini: Ambulatório e Internação.

Comitê de Ética em Pesquisa do Centro Infantil Boldrini: Rua Gabriel Porto, 1270, Cidade Universitária, Campinas-SP, CEP. 13083-210, Tel. (19) 3787-5000, www.boldrini.org.br

\section{Termo de Consentimento Livre e Esclarecido}

Por este instrumento, eu

declaro ter sido devidamente esclarecido(a) pelas psicólogas Marina Noronha Ferraz de Arruda e Elisa Maria Perina que esta pesquisa tem como objetivo verificar e compreender as vivências das crianças com recidiva de câncer, diante deste momento de tratamento. Afirmo ter conhecimento de que será realizada uma entrevista e a aplicação do procedimento de desenhos-estórias com a criança, durante as consultas de ambulatório ou na unidade de internação. Compreendi que estes recursos diagnósticos não provocam nenhum tipo de risco ou prejuízo na sua realização. 
Estou ciente de que essas descobertas poderão ser utilizadas no futuro e que talvez meu/minha filho(a) não se beneficie delas, mas que minha participação poderá Centro Infantil contribuir para a melhoria do atendimento às crianças nessa fase do tratamento. Fui Boldrini comunicada ainda de que tenho a liberdade para escolher não autorizar a inclusão de meu filho(a) neste estudo sem que haja qualquer prejuízo para seu tratamento. Declaro, ainda, que tenho conhecimento de que os resultados desse trabalho serão utilizados na pesquisa de conclusão do curso de aprimoramento e especialização em Psico-Oncologia Pediátrica da FCM/Unicamp da pesquisadora, podendo ser divulgados e tornados públicos através de publicações científicas, preservando-se a identidade de todos os participantes.

Após convenientemente esclarecido(a) pela pesquisadora e ter entendido o que me foi explicado, aceito participar do presente Projeto de Pesquisa e autorizo a participação de meu filho(a).

Campinas, de de 2011.

Assinatura do responsável legal
Assinatura do pesquisador (carimbo ou nome legível) 
